\title{
IDENTITY, SPACE, PLACE AND POSTSECONDARY EDUCATION: EXPLORING THE EDUCATIONAL PERCEPTIONS AND AMBITIONS OF YOUTH OF THE RURAL COMMUNITIES OF \\ MANITOULIN ISLAND
}

\author{
By \\ KIMBERLY M. WILSON \\ A thesis submitted to \\ the Faculty of Graduate Studies and Research \\ in partial fulfillment of \\ the requirements for the degree of \\ Master of Arts \\ Department of Geography and Environmental Studies \\ Carleton University \\ Ottawa, Ontario
}

(C) Kimberly M. Wilson 2009 


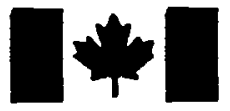

Library and Archives

Canada

Published Heritage

Branch

395 Wellington Street

Ottawa ON K1A ON4

Canada
Bibliothèque et

Archives Canada

Direction du

Patrimoine de l'édition

395 , rue Wellington

Ottawa ON K1A ON4

Canada
Your file Votre référence

ISBN: 978-0-494-60281-2

Our file Notre référence

ISBN: 978-0-494-60281-2
NOTICE:

The author has granted a nonexclusive license allowing Library and Archives Canada to reproduce, publish, archive, preserve, conserve, communicate to the public by telecommunication or on the Internet, loan, distribute and sell theses worldwide, for commercial or noncommercial purposes, in microform, paper, electronic and/or any other formats.

The author retains copyright ownership and moral rights in this thesis. Neither the thesis nor substantial extracts from it may be printed or otherwise reproduced without the author's permission.
AVIS:

L'auteur a accordé une licence non exclusive permettant à la Bibliothèque et Archives Canada de reproduire, publier, archiver, sauvegarder, conserver, transmettre au public par télécommunication ou par l'Internet, prêter, distribuer et vendre des thèses partout dans le monde, à des fins commerciales ou autres, sur support microforme, papier, électronique et/ou autres formats.

L'auteur conserve la propriété du droit d'auteur et des droits moraux qui protège cette thèse. Ni la thèse ni des extraits substantiels de celle-ci ne doivent être imprimés ou autrement reproduits sans son autorisation.
In compliance with the Canadian Privacy Act some supporting forms may have been removed from this thesis.

While these forms may be included in the document page count, their removal does not represent any loss of content from the thesis.
Conformément à la loi canadienne sur la protection de la vie privée, quelques formulaires secondaires ont été enlevés de cette thèse.

Bien que ces formulaires aient inclus dans la pagination, il n'y aura aucun contenu manquant. 
(C) Kimberly M. Wilson 2009 


\begin{abstract}
Scholarly literature, which focuses on the educational attainment and decision-making of youth, has taken a variety of approaches to answer the questions: who goes, who stays and why? Many studies have sought to identify the relationships between educational attainment and factors such as personal and family income, parental education, gender, ethnicity, and family structure. Although quite a few studies have identified regional differences in educational attainment between rural and urban communities, it is still unclear why postsecondary participation rates remain lower among rural youth. More recent studies seek to explain these differences.

Using a Geographies of Practice approach, this thesis seeks to explore the perceptions and ambitions of rural high school students towards higher education. By conducting a qualitative case-study of a group of rural youth on Manitoulin Island in northern Ontario, this study attempts to investigate how localities influence educational, occupation and mobility choices. The findings of this study suggest that there is indeed a social-spatial relationship that influences the educational and career choices of those youth planning to leave Manitoulin Island for higher education. Yet, this group of youth have adopted several coping mechanisms to counter the influence of their localities, and the effects of socioeconomic status, distance and the loss of important social networks.
\end{abstract}




\section{Acknowledgments}

I would like thank all the people who took the time to be a part of this journey with me.

I especially want to thank my advisor, Dr. Fran Klodawsky, for her guidance during my research and study at Carleton University. Her patience and feedback throughout my studies have been an important element in the progression of this thesis and my own personal and academic development.

I would like to send out a huge thank you to Dr. Jan Buley, a secondary supervisor for this thesis. Her energy and enthusiasm for research, and for being a part of my research, were key factors in maintaining my love for this project. A dose of her positive vibes and cheery personality were often the perfect remedy to revive my spirits during the most difficult parts of this journey.

I would also like to thank the Rainbow District School Board, and the staff and students at Manitoulin Secondary, for allowing me to conduct my research there and for making the data collection just a wonderful experience for me. I really felt welcomed, and am looking forward to returning to the school and community to share my findings.

A special thank you to Doreen Duncanson for opending her home to me while I was collecting data on Manitoulin Island. I would also like to thank Ken Duncanson for the use of his truck during my stay. Your collective generosity was integral to the success of my project. Thank you both.

Thank you to all my professors, including Dr. Fiona Mackenzie, for the part they played in my academic development. Over the last two years they provided an open invitation to talk about my research, and provided much encouragement and support.

I would also like to thank my many friends and colleagues at Carleton University and Laurentian University. I enjoyed the time we spent drinking tea and beer and eating pitas. You allowed me to share my ideas and provided alternative perspectives which helped me work through many hurdles, and provided me with an opportunity to create many valued memories.

A warm thank you goes out to my family for all your love and support. I would especially like to thank Drakken for being my personal alarm clock and travel buddy. I would also like to thank Rhonda for opening your home and heart to me. You are like a sister to me and I am so grateful you were a part of this journey.

Finally, I would like to thank my fiancé Jamie for his love and dedication to me and my studies over the last two years. I could not have done this without you.

"I can no other answer make, but, thanks, and thanks" William Shakespeare 


\section{Table of Contents}

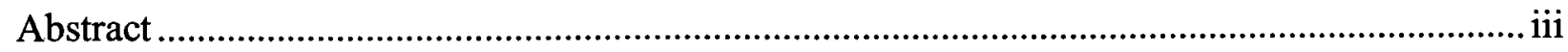

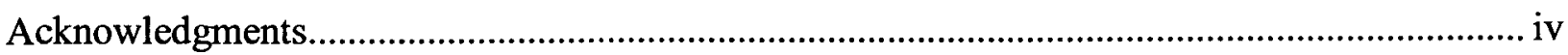

Table of Contents ....................................................................................................................

List of Maps and Figures .......................................................................................................... viii

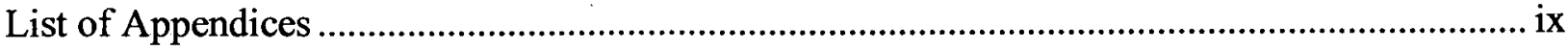

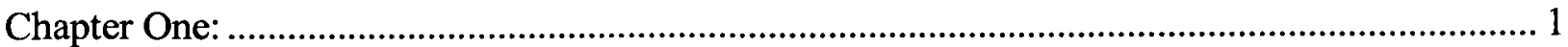

Introduction:

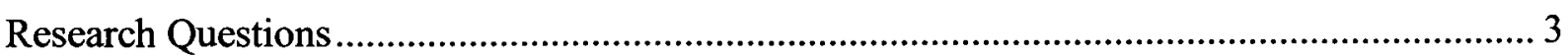

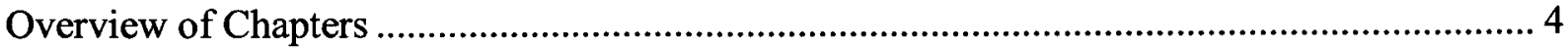

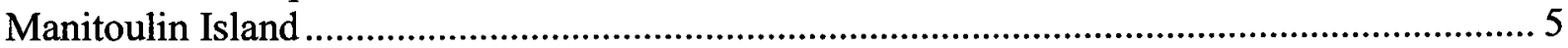

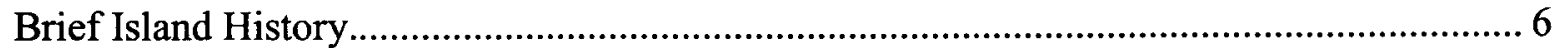

Present Day Manitoulin ................................................................................................ 11

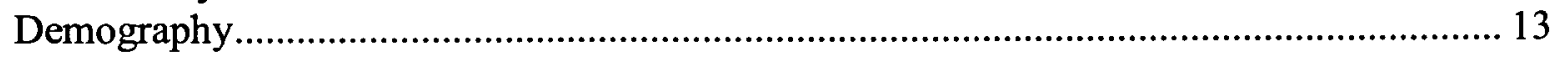

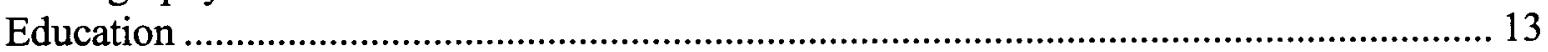

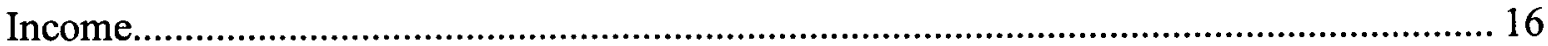

Why Manitoulin as a Research Site? ............................................................................... 18

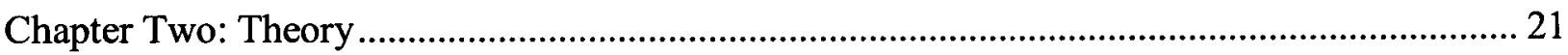

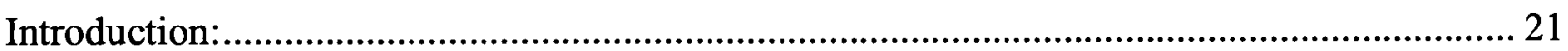

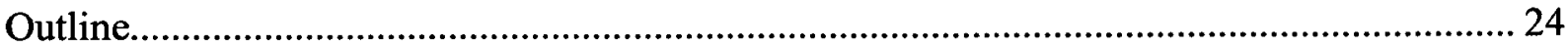

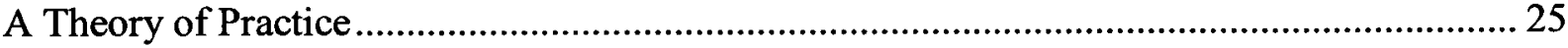

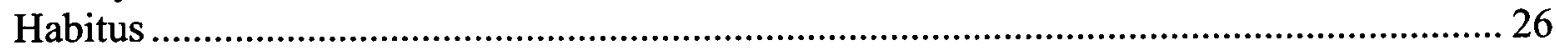

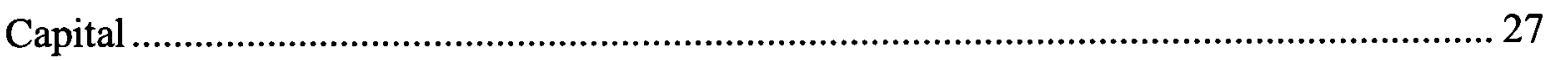

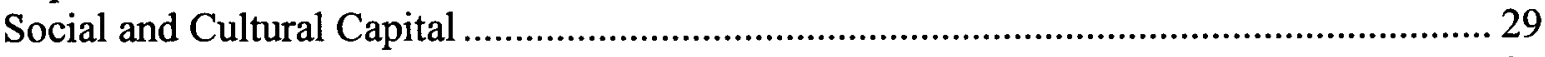

Habitus as Sense of Place ………………....................................................................... 31

Agency and Practice …………………........................................................................ 32

Educational Attainment .......................................................................................................... 33

Family Background and Socioeconomic Status .................................................................. 34

Socioeconomic Status and Geography.................................................................................. 36

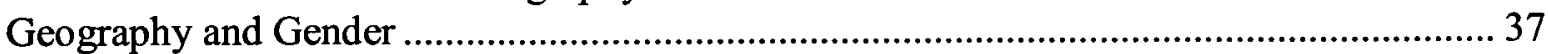

Explaining Why Geography Affects Postsecondary Education .............................................. 38

Community and Social Capital ............................................................................................. 39

Mobility, Sense of Place, and Social Capital ........................................................................... 40

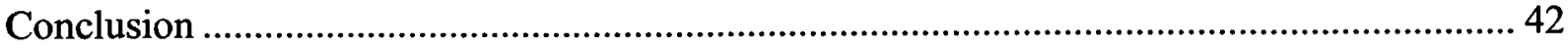

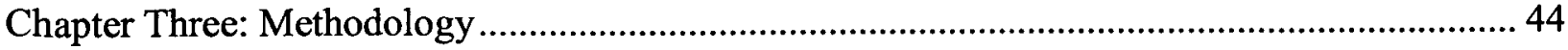

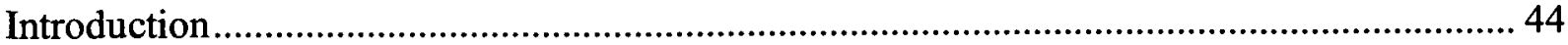

Adopting a Suitable Methodology for working with Young People ........................................... 45

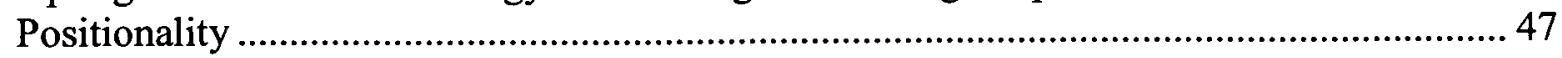

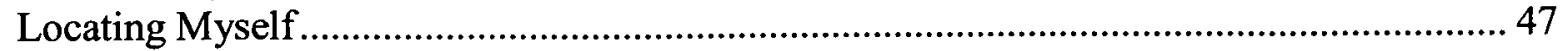

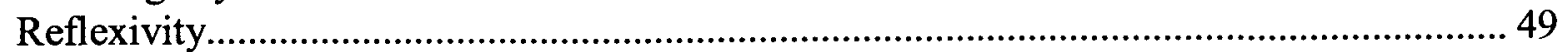

Reflecting on My Positionality ................................................................................................ 49 
Reflecting on My Positionality ......................................................................................... 49

Methodological Issues and Relations of Power ............................................................... 51

'Outsider', 'Insider' and 'Between-ness': Gaining Access to Participants................................5 52

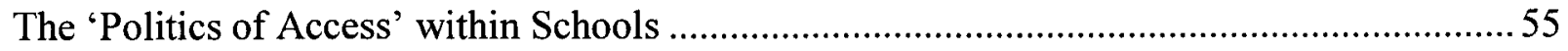

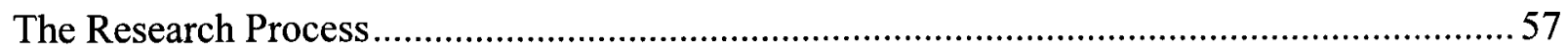

Pre-Fieldwork Approach ........................................................................................... 58

Research Focus: Rural High School Students as a Unit of Analysis ....................................58

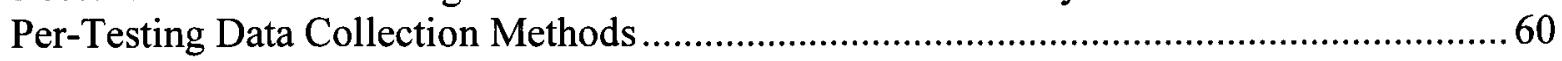

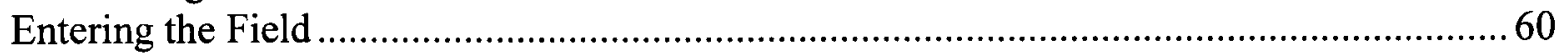

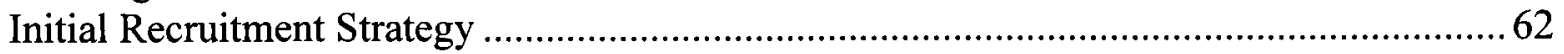

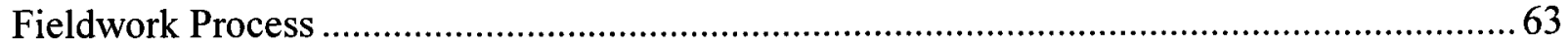

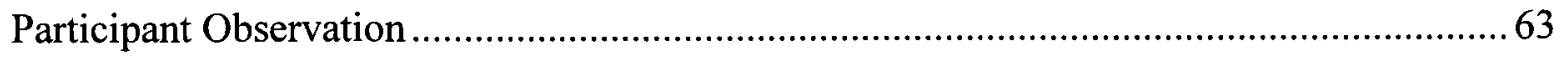

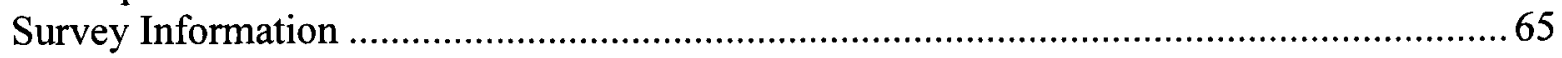

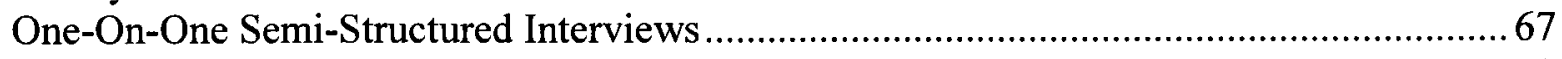

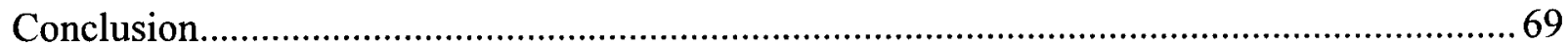

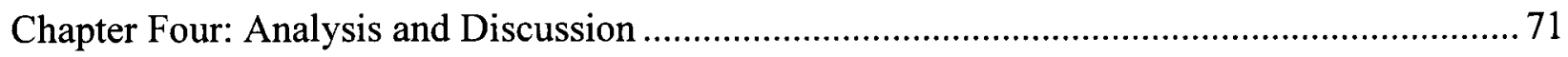

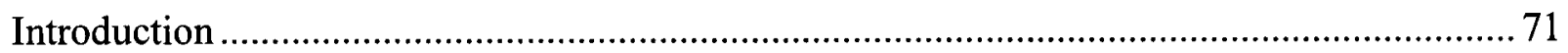

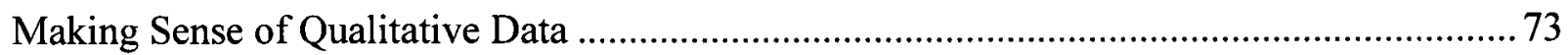

Making Sense of Quantitative Data ................................................................................... 75

Preliminary Remarks about the Data ................................................................................

Social Capital and Sense of Community ......................................................................... 75

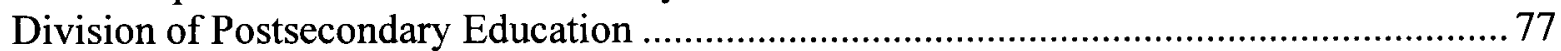

Youth's Perceptions of Postsecondary Education..................................................................78

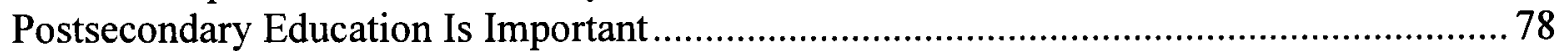

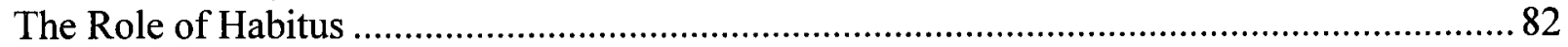

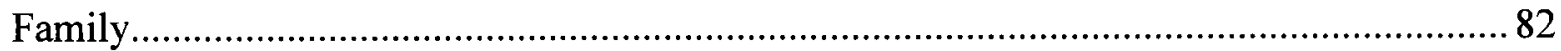

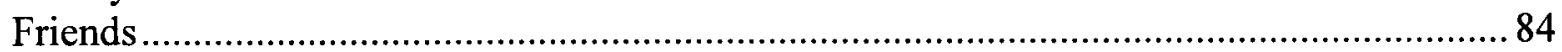

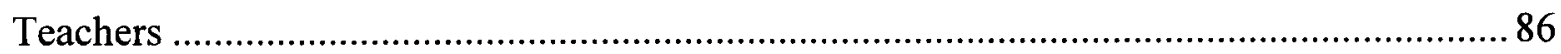

Community and Community Members...............................................................................8 88

The Influence of Locality and Capital Perceptions of Postsecondary Education ......................91

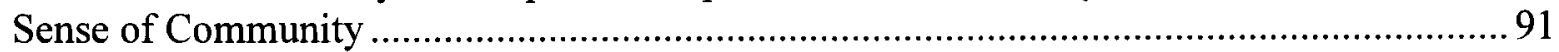

Why Some Rural Youth Choose to Leave ………............................................................93

The Effects of Geography on Youth Mobility ..................................................................96

The Influence of Social Capital on Issues of Distance ............................................................97

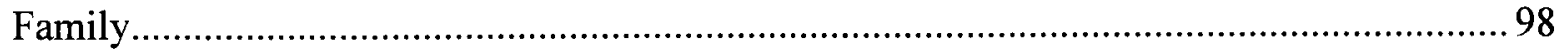

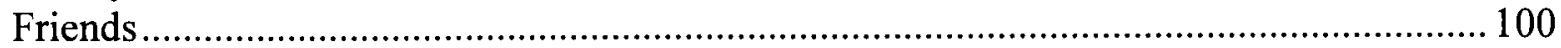

The Effects of the Local Economy on Mobility Choices.................................................... 101

Ideologies about Males and Females and Postsecondary Education ................................... 103

Conclusion................................................................................................................. 105

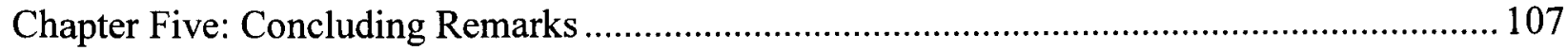

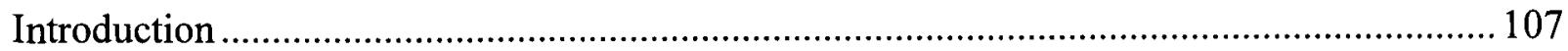

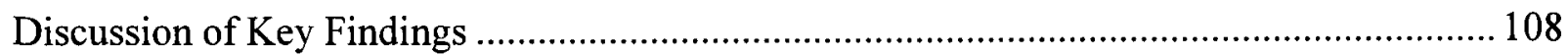

Limitations and Areas of Future Research ........................................................................ 110

Concluding Thoughts .................................................................................................... 112 


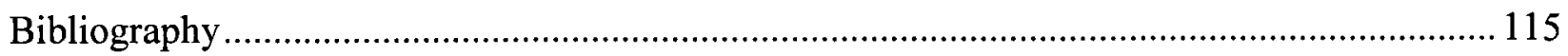




\section{List of Tables}

Table 1.1: Educational Attainment Expressed as Percent...................................15

Table 1.2: Median Income Distributions of Persons 15 Years of Age and Over...................16

Table 1.3: Distributions of Labour Force 15 Year of Age and Over...........................17

Table 4.1: List of Established Codes Vis-à-vis Place and Educational Aspirations................74

Table 4.2: Does Cost Influence Rural Youth's PSE Choices? .................................81

Table 4.3: Students' Future Paths and Their Parents' Level of Education.......................83

Table 4.4: Rural Youth's Goals and Ambitions after High School .............................83

Table 4.5: Rural Youth's Mobility Plans..................................................94

Table 4.6: Self-Reported Career Choices of Rural Youth.......................................103 


\section{List of Maps and Figures}

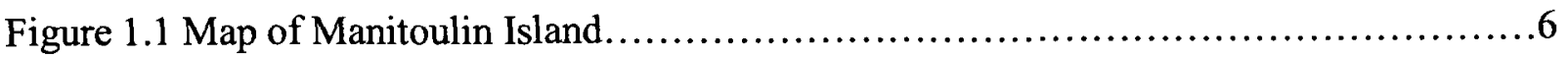

Figure 1.2 The Little Current Swing Bridge .........................................

Figure 1.3 The MS Chi-Cheemaun...................................................

Figure 1.4 Map of First Nations Reserves on Manitoulin Island...........................12

Figure 1.5 Population Distribution for Manitoulin Island, Ontario ........................14

Figure 1.6: Education Attainment Expressed as Percent ............................... 15 


\section{List of Appendices}

Appendix A - Ethics Approval from the Rainbow District School Board....................121

Appendix B - Ethics Approval from Carleton University ...............................123

Appendix C - PA Announcement to the Members of Manitoulin Secondary School

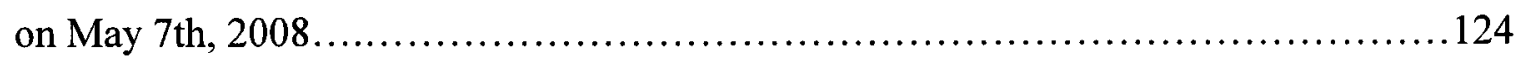

Appendix D - Accent and Consent Form for Student Participants..........................125

Appendix E - Memo Administer to the Teaching Staff at Secondary School

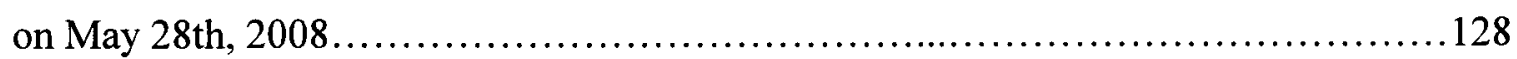

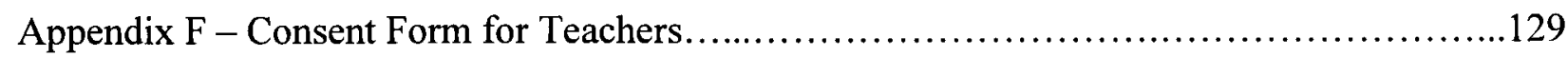

Appendix G - Questionnaire................................................. 130

Appendix H-Protocol for Student Interviews......................................... 135

Appendix I - Student Responses to Questionnaire -Select Questions.......................137

Appendix J - Flowchart Illustrating Thematic Connections.............................. 140 


\section{Chapter One:}

\section{Introduction:}

On September $30^{\text {th }}, 1983$, at the Sudbury General Hospital, premature fraternal twins were born, one boy and one girl. Like most brother and sister twins, they have remained very closely connected to this day. But, from an early age, these two children were set on different life courses. The brother was more immature than his sister, and was retained for one extra year in his primary education. The sister, a shy and quiet little girl, moved forward through the grade levels, and although she struggled with reading and spelling, she was a sweet child who often won the hearts of her teachers. Unlike her brother, she loved going to school, and cared deeply for her teachers, always trying to do her best in school. Seeing her efforts, her teachers in turn provided extra attention and encouragement to her, and she became a teacher's pet on several occasions.

The parents of these twins were loving and supportive people, but, having never attained a high school education themselves, the only educational aspiration they had for any of their children was that they graduate from high school. Growing up in a remote community outside Sudbury, Ontario, the twins were seldom exposed to people who had a postsecondary education. Consequently, the goals and values of a postsecondary education were not as significant to this family. The brother was a good child, and although he struggled through high school with his academics, failing classes now and then, he was determined to graduate despite being ill throughout his formative years. His illness resulted in being absent from school for the whole of a semester and he had developed no real goals to pursue any form of career training after that. His friends were in a similar situation. Many just wanted to finish high school and be free from 
school routines. With this attitude, some of his friends never ended up finishing high school at all. Somehow, despite it all, this twin boy persevered and completed high school.

His sister, on the other hand, started high school as a general level student, but after grade nine she began taking courses in the advanced level and began making friends with her peers in these courses. By the end of grade eleven, she was taking all advanced courses, and met a boy who was destined for university, and who had parents who were very supportive. These adults encouraged her to go on to university as well. So she did. Or, I will say, I did.

Today, my bother Kelly works in the not-for-profit sector, and is a supervisor in a store. Although he works full-time, like many retail or not-for-profit sector jobs, there is often no real opportunity for advancement. As for myself, I have gone on to complete an undergraduate degree, a Bachelor of Education, and am now working on the completion of my Master's degree at Carleton University, culminating in this thesis. To this day, I have wondered why I achieved a university education while my brother and other siblings did not. This has lingered in the back of my mind and has been at the heart of my investigation into who pursues a postsecondary education, who stays, and why?

There is no disputing the fact that in today's changing economy, education has become an essential stepping stone into the market place and workforce. In Canada, higher education has been targeted as "one of the key vehicles for producing a labour force ready to meet the challenges of the new workplace" (Butlin, 1999, p 9). However, access to a postsecondary education still remains a challenge in many rural communities across Canada. As Michael Corbett points out, "the normalization process of making protracted schooling and higher education automatic and habitual is not yet well established in some Canadian rural and coastal communities" (Corbett, 2005, p 53). Schooling, and specifically access to postsecondary 
schooling in rural and costal communities, (including northern communities), remains a significant challenge for youth and educators (Corbett, 2005).

An underlying understanding of this thesis is that places are importance spaces of identity construction (Massey, 2001; Aitken, 2001; Castree, 2003; Thrift, 2003). As such, this thesis seeks to explore the importance of localities as they relate to a person's level of educational attainment. This study attempts to investigate how people's educational, occupational and mobility choices are influenced by growing up in a remote island community in northern Ontario. Since many rural communities across Canada tend to have lower levels of educational attainment, this study explores why this fact is so.

\section{Research Questions}

This investigation is comprised of two distinct research questions: 1 . What are the perceptions and ambitions of rural high school students towards higher education? This presiding question was at the heart of a number of more precise investigations throughout the research process: Do these young people value higher education? How do these students develop these opinions? 2. What is the role of place, space and identity in forming these attitudes? As with the first research question, this question resulted in subsequent investigatory questions: Does growing up in a rural location influence a student's educational and career choices? Does distance influence rural students' choices to pursue a postsecondary education? Does distance influence the choice of where one attends school? How greatly does the fear of leaving home impact the process? Does the local economy influence the distance travelled by youth pursuing a postsecondary education, and the programs they choose to pursue? Using a case study approach, these two research questions have propelled me to better understand the complex process of the 
construction of social-spatial identities, their relationship to rural youths' education choices and their occupational decisions making.

\section{Overview of Chapters}

Chapter Two provides a review of the literature in order to establish the theoretical framework of this thesis. This chapter examines three bodies of literature: educational attainment, locality (specifically rurality of communities), and youth geographies as it pertains to mobility, and outlines the relationship between localities and educational attainment. In addition, Pierre Bourdieu's Theory of Practice and his concepts of habitus, and social and cultural capital are used as a lens to understand the social-spatial relationships which affect rural youth's choices in pursuing or avoiding a postsecondary education. Lastly, this chapter also explores the concepts of agency, sense of place, and the importance of geography, specifically distance, as they relate to a youth's educational, occupational and mobility choices.

Chapter Three provides a detailed description of the qualitative methodology used in this research study. By adopting a feminist approach, I attempt to make transparent my role in data collection and analysis. Since there has been a tradition of excluding children and young people in qualitative research, this study takes into account that young peoples' values and perspectives differ from adults. Thus, it is essential to elicit their perspectives and understanding in order to gain an appreciation of the complexity of the social worlds in which youth live. The use of interview as a qualitative approach is also discussed in chapter three.

Chapter Four details the perceptions that youth hold about postsecondary education and the sources of these ideologies, as well as the implications of distance and proximity on youth's postsecondary education, career and mobility choices. Utilizing the theory, this chapter also 
explores the complex relationship between educational and occupational values and goals and one's social and physical environment.

Finally, Chapter Five outlines some of the key findings of the study, discussing the role of various forms of social capital on influencing students' values towards postsecondary education and the effects of localities on students' after high school decisions. This chapter also discusses the limitations of the research and areas for future study.

The remainder of Chapter One describes the research location. Manitoulin Island (the Island) has a lot in common with many rural communities in Canada where educational attainment levels of the population are lower than the provincial and federal averages. After providing a brief history of the research location, this chapter will describe the contemporary context of the Island, discussing its currently demographic and socio-economic characteristics. This chapter concludes with a justification of the use of this area as a research site for this study.

\section{Manitoulin Island}

Manitoulin Island is situated in Lake Huron, and is the largest island located in a freshwater body in the world. It is $129 \mathrm{~km}$ long, varies in width from 4 to $48 \mathrm{~km}$, and has a total area of 2,766 km2. Its north shore forms one side of the North Channel, while the east coast, along with the Bruce Peninsula, forms Georgian Bay (See Figure 1.1). With its over eighty inland lakes, Manitoulin Island is considered to be a place of incredible beauty and serene landscapes, attracting many tourists, including myself.

There are two conventional ways of getting to Manitoulin Island. The first is from the north, traveling about $70 \mathrm{~km}$ west from Sudbury on the Trans-Canada Highway and then south on Highway 6, through Espanola. Year-round motor-vehicle access to the Island is possible by 
crossing the one-lane Little Current Swing Bridge, which crosses the North Channel at Little Current (Figure 1.2). Originally, a train bridge built in 1913, it was converted to better accommodate motor vehicles as well as the train in 1945 . The alternate way to the Island is from the south, via ferry. Currently, the MS Chi-Cheemaun (Ojibwa for "Big Canoe") provides daily seasonal motor-vehicle transportation on and off the Island (Figure 1.3). Available between late May and early October, locals and visitors can access the Island from the south, taking the ferry from Tobermory at the northern point of the Bruce Peninsula, and arriving at South Baymouth on Manitoulin Island. There are also two airports, and many marinas and docks along the shores of the island which provide access, especially for tourist populations during the summer months.

\section{Figure 1.1: Map of Manitoulin Island}

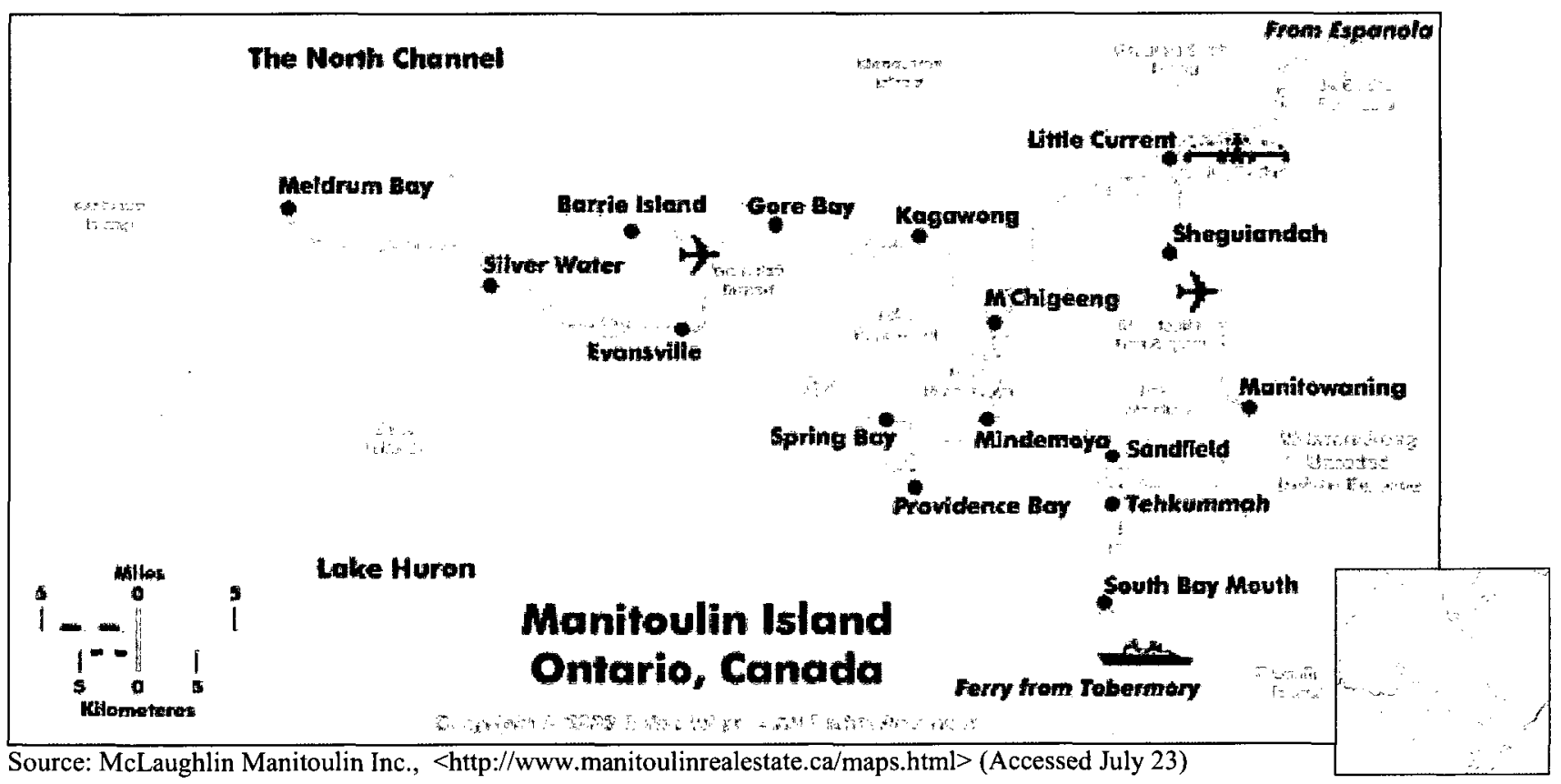

\section{Brief Island History}

Manitoulin Island has a relatively long history which has shaped its current demographics. The following section outlines Manitoulin Island's settlement history to explain why Manitoulin Island has a large Aboriginal population, and why it only has a relatively small 
Figure 1.2: Little Current Swing-Bridge

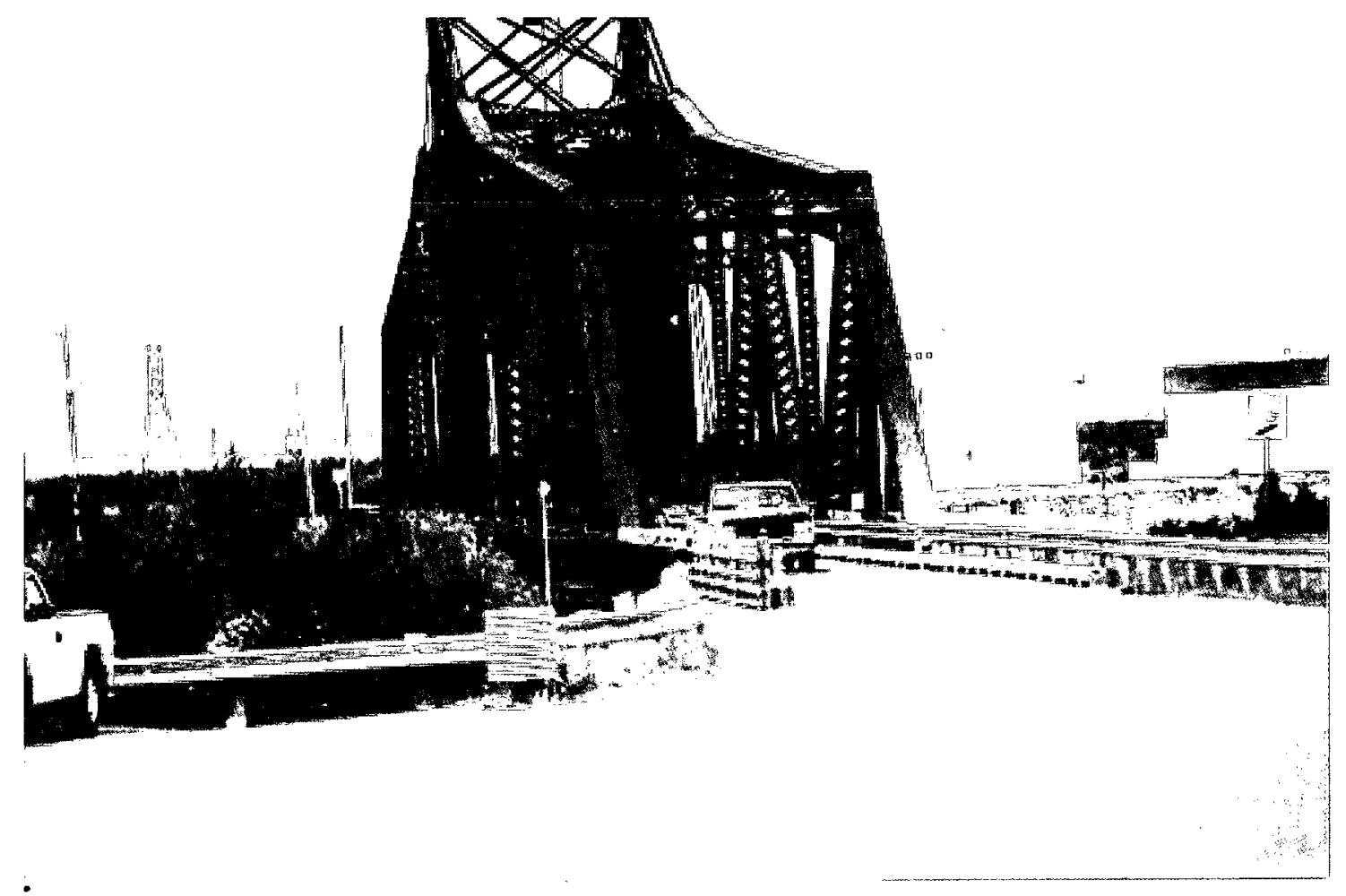

Figure 1.3: The MS Chi-Cheemaun

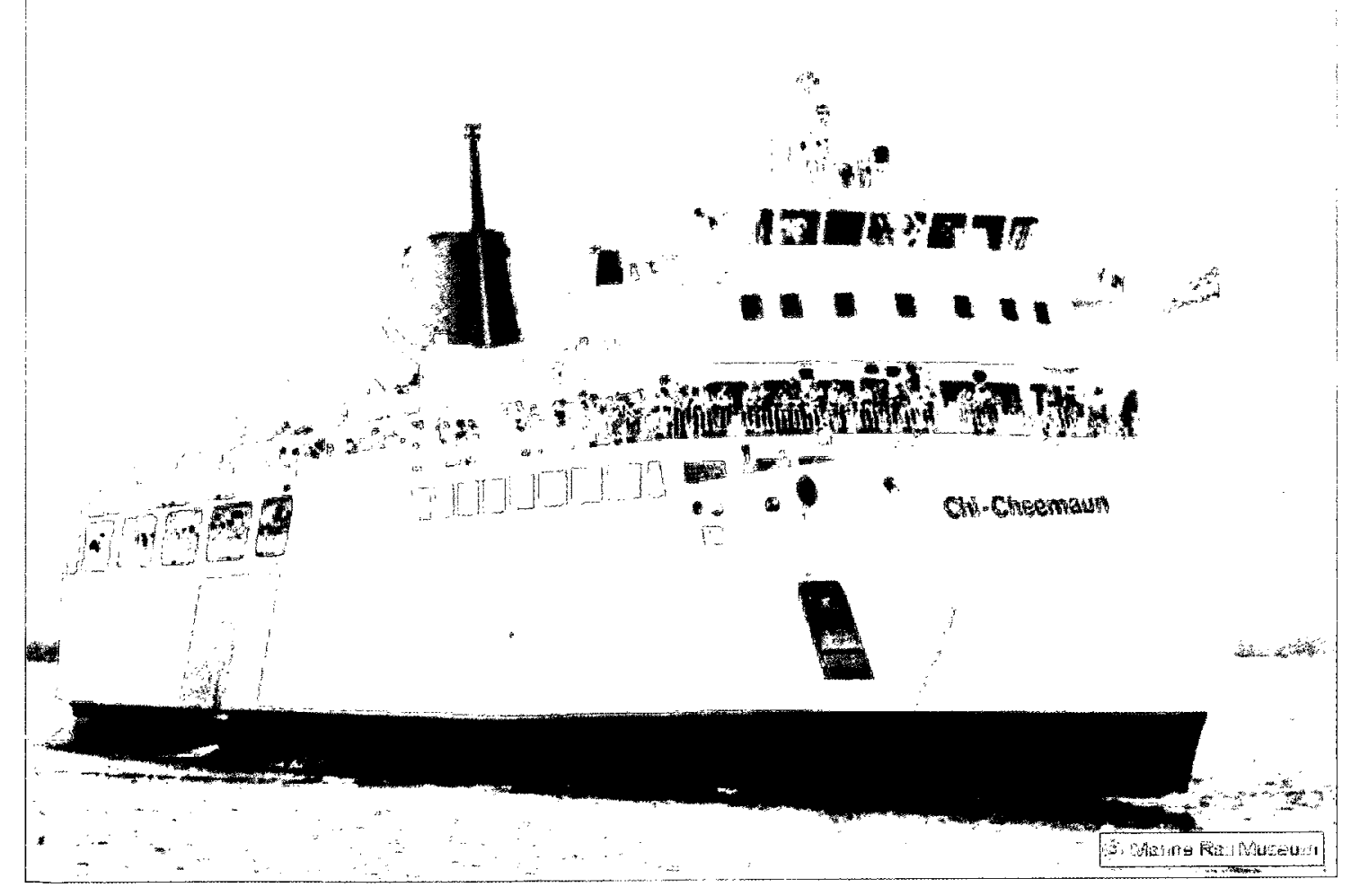


non-aboriginal population. This history section will also highlight why the economic development has primarily been limited to agriculture, forestry and tourism.

Based on archeological evidence, it is believed that Indigenous people have been using Manitoulin Island for about 9500 years. Based on oral history of the Anishinaabee Peoples, tribes of the Anishinabek migrated from a distant land from the east by boat. Guided by the Megis (a great shell), the Anishinabek migrated down the St. Lawrence into the Great Lakes until they finally reached Manitoulin Island. Manitoulin Island is considered a sacred place, where many Chiefs are buried, and Grand Council meetings have taken place.

It is unclear exactly when first European contact occurred with the inhabitants of Manitoulin Island. However, the original relationship with the French was a positive one, established through trade. Very little is known of the first European settlement on Manitoulin Island. The first settlement is believed to have been established by a Jesuit missionary by the name of Father Joseph Poncet in 1648. Father Poncet is reported to be the first resident of 'Ilede-Ste-Marie' or 'Ekaentoton', on Manitoulin Island, but the exact site of Poncet's mission has yet to be determined. Like many missionaries before him, Poncet attempted to educate, civilize and convert the Aboriginal Peoples to/through Christianity. Contact with the Europeans resulted in the spread of European diseases which killed many Aboriginal People. This invasion of illnesses is believed to have reduced the Aboriginal population in Canada by approximately $90 \%$. With the Huron Nations' population weakened due to European disease, the Iroquois Nations to the south saw an opportunity to conquer their enemies and they began to attack Huron settlements. In 1650, the raiding of the Iroquois Nations caused Father Poncet and the Huron people to begin fleeing Manitoulin Island, and the Manitoulin Mission. By 1651, about two hundred people had 
left Manitoulin Island for Quebec City to join a native settlement on the Ile d'Orleans. In 1652, the Iroquois attacked the Odawa, the Hurons' allies, and drove the remaining Manitoulin residents off of the island. According to oral tradition, Manitoulin Island was deserted for almost a hundred and fifty years because the Huron people had set fire to the island as they were leaving in order to cleanse the island of disease. It took more than a century for vegetation and wildlife to return to their former state. Therefore, it is believed that besides the occasional visit of Aboriginal fishing and hunting expeditions, Manitoulin Island remained uninhabited until the next mission was established around 1833, at present day Wikwemikong (meaning "bay of beavers").

The resettlement of Manitoulin Island was prompted by the relocation of many British allies following the American Revolution and the War of 1812. Both Aboriginal and nonAboriginal allies who previously resided in the boundary regions of the United States, began resettling in Canada. As a result, many First Nations people found their way back to their homeland of Manitoulin or, 'Ekaentoton', and began to settle at Wikwemikong around 1833. By 1839, the Odawa population at Wikwemikong had increased to about 350 . In 1844 , the Jesuits took over the Wikwemikong mission and began to organize instruction in agriculture, carpentry, and boatbuilding. Increased migration resulted in the settlement of smaller villages near Wikwemikong, such as Wikwemikongsing, Chitewaigunning, and Buzwh.

After the war of 1812, the colonial authorities no longer saw the First Nation People as solely allies, but as a people who needed help to integrate into British society. Therefore, there were attempts to assimilate the Aboriginal Peoples though the establishment of missions, schools, churches, and by offering formal training in agriculture and various trades. However, when Francis Bond Head became Lieutenant Governor, he felt that assimilation initiatives were 
being resisted by the Aboriginal Peoples in the region. It was obvious to him that many Aboriginal People preferred their traditional way of life. Thus, during a meeting with the Odawa, Ojibwe and Pottawatomi First Nations people living on Manitoulin Island, (without proper sanction of the British government) he established the treaty of 1836, where the Aboriginal People agreed to relinquish their claims to the other islands of Georgian Bay. Under the treaty, the Manitoulin First Nations People also agreed to allow other Aboriginal Peoples to join them on the Island. As a result, Manitoulin Island became a secluded haven for various Aboriginal populations, where they could live without influence from white people. This treaty also allowed the British government to settle in the surrounding areas, and begin using the resources of the area.

In 1861 the British government, influenced by increasing need for more arable land, decided that the First Nations People of Manitoulin Island (now totaling about 1,350 people) did not warrant the occupation of the entire island. Thus, they attempted future negotiations with the Aboriginal People to try and persuade them to cede the island and allow non-Aboriginal settlements. The first round of offers in August 1861 was rejected by the Aboriginal People on Manitoulin Island. On October $5^{\text {th }}, 1862$ the second round of offers took place, and again, the Aboriginal People were hesitant about accepting the offer. The government allowed a day for the First Nations People of Manitoulin Island to reconsider, and invited only those who wished to participate in the treaty to come back the next day to negotiate further. The Aboriginal People living in Wikwemikong were the largest population of First Nations People on Manitoulin Island, and were opposed to any treaty. They did not return the next day, and therefore did not give up their land to the government. On October $6^{\text {th }}, 1862$ the Manitowaning Treaty was signed and this resulted in the government negotiating with only 40 percent of the First Nations People 
on Manitoulin Island, and acquiring 80 percent of the Island's land for non-Aboriginal settlement. As a result, over the next decade, the reserves of Sheguiandah, M'Chigeeng (formally known as West Bay), Sheshequaning, Obidjiwang became official communities. By 1874 nonAboriginal settlements were established at the former Aboriginal settlements of Kagawong, Gore Bay, Providence Bay, Michael's Bay and Little Current. To this day, Wikwemikong is recognized as the only official Unceded Indian Reserve in Canada, since the inhabitants never relinquished title of their land to the government via treaty or otherwise. The Wikwemikong First Nations has a population of 2,387 people. Since the community members of Wikwemikong have their own federally funded Aboriginal primary and secondary schools, the youth do not attend Manitoulin Secondary School, the focus school in this study.

As a result of Manitoulin Island's long history, large Aboriginal population, and physical attractions, the Island had become a central tourist destination for many. However, as will be discussed below, it has also remained fairly undeveloped, making this a good location for this study.

\section{Present Day Manitoulin}

At present, only $10 \%$ of the Island is populated (LAMBAC, 2006). The Island has two incorporated towns (Northeastern Manitoulin and the Islands and Gore Bay), eight townships (Assiginack, Billings, Burpee and Mills, Central Manitoulin, Dawson, Gordon, Robinson and Tehkummah) and six Anishinaabe reservations (M'Chigeeng, Sheguiandah, Sheshegwaning, Aundeck Omni Kaning, Wikwemikong and Zhiibaahaasing.) (Please refer to Figure 1.4 for a contemporary map of the location of the First Nations communities on Manitoulin Island). Manitoulin Island, along with several smaller neighbouring islands, makes up the Manitoulin 
Figure 1.4: Map of First Nations Reserves on Manitoulin Island

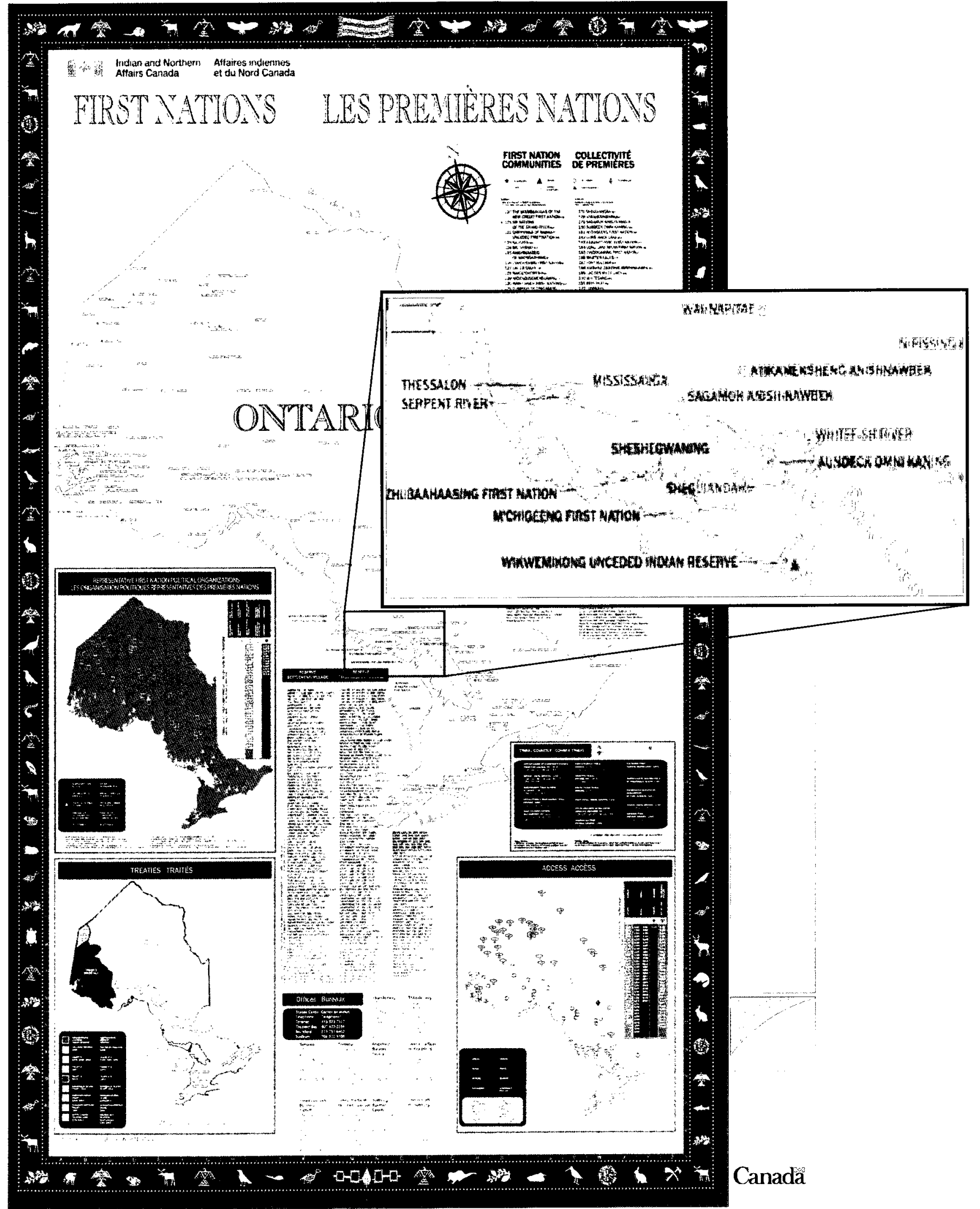

Source: Indian and Northern Affairs Canada <http://www.ainc-inac.gc.ca/ai/scr/on/rp/mcarte/qwerty-eng.asp > (accessed May 13, 2009) 
District census division of Ontario. The population of Manitoulin Island, according to the 2006 Census of Populations for the Census District, is 13,090 people. However, during the summer months, the population is believed to grow by more than a quarter due to the various physical attractions and recreational activities the Island has to offer, including fishing and boating (Manitoulin Living, 2009).

\section{Demography}

Just like many other Canadian rural communities, Manitoulin Island residents struggle to retain their young people. Figure 1.5 illustrates the breakdown of the populations by age. As is evident, there is a significant decrease in the number of young people between 20 and 34 years of age. As might be expected, many young people in this age group leave the Island to attain some aspect of formal education or to seek employment opportunities. However, there is also a significant percentage of the population 15 years of age and older, who did not even complete high school $(\sim 32 \%)$, or continue on to postsecondary studies. Without this education, these students are less mobile and therefore less likely to leave their communities at all (Corbett, 2001).

\section{Education}

There are two main high schools on Manitoulin Island, Manitoulin Secondary School in M'Chigeeng, and Wasse-Abin High School on Wikwemikong. There are quite a few adult education programs across the Island including the Wikwemikong Adult Education, M'Chigeeng Adult and Continuing Education Program, and the Manitoulin Literacy Council located in Mindemoya. Cambrian College has a campus located in Little Current, and it offers an Academic Upgrading Program providing training in English, maths, sciences, computer skills, and study skills, in addition to a few postsecondary programs. There is also an Aboriginal postsecondary 
institution, the Kenjgewin Teg Education Institute, which is located in the M'Chigeeng First Nations reserve, which offers both secondary and postsecondary accreditation. The institute has a permanent staff of fourteen teachers and offers a variety of Aboriginal-centred programs such as: Anishinaabemowin Immersion Certificate Program; Aboriginal Tourism Program; Community Economic and Social Development Program; First Nation Business Administration Certificate; and Aboriginal Teacher Education Program.

Figure 1.5: Graph of Population Distribution for Manitoulin Island, Ontario

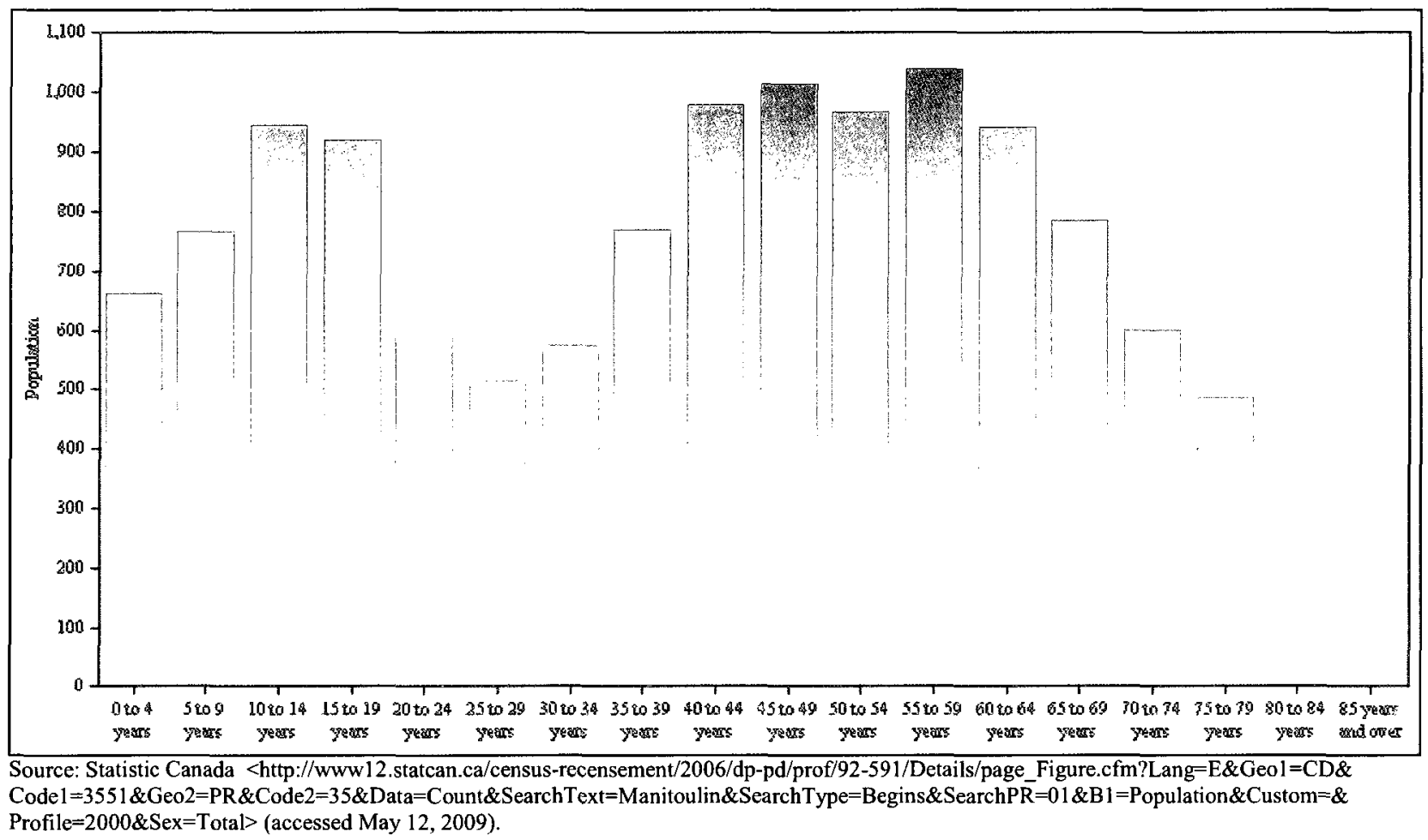

As is illustrated in Table 1.1, the educational attainment of the Manitoulin District is significantly lower than the provincial average (also see Figure 1.6). The proportion of the population of Manitoulin Island who has not completed high school is 10 percent higher than that of the province ( $32 \%$ vs. $22 \%$ ), and the proportion of the population who has completed high school is slightly lower than the provincial average (about $25 \%$ vs. $27 \%$ ). While the 
proportion of the population on Manitoulin Island who has a college education is slightly higher than the provincial average ( $19 \%$ vs. $18 \%)$, only 9 percent of the total population has a university education, in comparison to the provincial average of 20.5 percent. It should also be noted, in line with provincial trends, that women on Manitoulin Island are more likely than men to attain a postsecondary education at both the college $(\sim 11 \%$ vs. $\sim 8 \%)$, and university $(\sim 5 \%$ vs. $\sim 4 \%)$

levels.

\section{Table 1.1: Education Attainment Expressed as Percent}

\begin{tabular}{|c|c|c|c|c|c|c|}
\hline & \multicolumn{3}{|c|}{ Manitoulin (Census division) } & \multicolumn{3}{|c|}{ Ontario (Province) } \\
\hline Characteristics & Total & Male & Female & Total & Male & Female \\
\hline Total population 15 years and over & 100.00 & 49.31 & 50.69 & 100.00 & 48.32 & 51.68 \\
\hline No certificate; diploma or degree & 32.47 & 16.14 & 16.28 & 22.24 & 10.78 & 11.45 \\
\hline High school certificate or equivalent & 24.80 & 11.45 & 13.35 & 26.77 & 12.43 & 14.34 \\
\hline Apprenticeship or trades certificate or diploma & 11.50 & 8.38 & 3.12 & 8.00 & 5.24 & 2.75 \\
\hline College; CEGEP or other non-university certificate or diploma & 19.12 & 7.95 & 11.12 & 18.38 & 7.97 & 10.41 \\
\hline University certificate or diploma below the bachelor level & 2.84 & 1.18 & 1.66 & 4.13 & 1.85 & 2.28 \\
\hline University certificate; diploma or degree & 9.37 & 4.16 & 5.16 & 20.49 & 10.05 & 10.44 \\
\hline
\end{tabular}

Source: Statistics Canada <http://www12.statcan.ca/census-recensement/2006/dp-pd/prof/92-591/Details/page.cfm?Lang=E\& Geo1 $=$ CD\&Code $1=3551 \& G e o 2=P R \& C o d e 2=35 \& D a t a=$ Count\&SearchText $=$ Manitoulin\&SearchType $=$ Begins\&SearchPR $=01 \&$ $\mathrm{B} 1=\mathrm{All} \&$ Custom $=>$ (accessed May 12, 2009)

\section{Figure 1.6: Education Attainment Expressed as Percent}

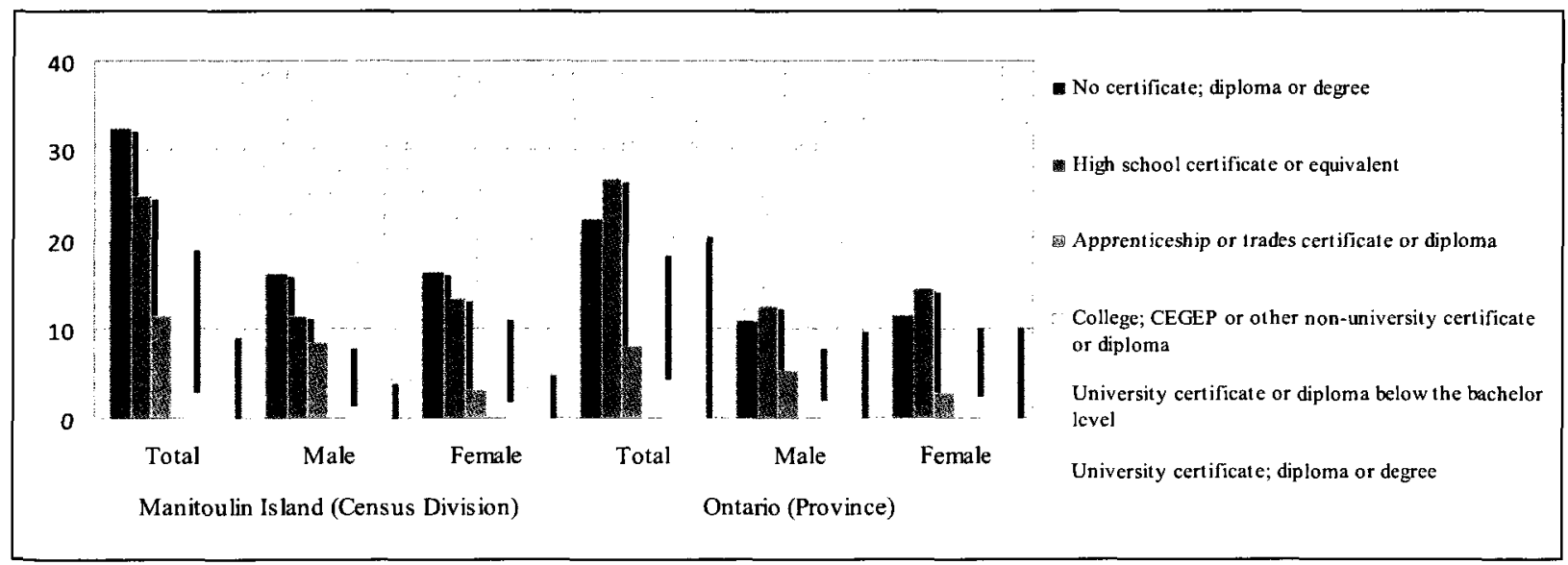

Source: Adapted from Statistics Canada <http://www12.statcan,ca/census-recensement/2006/dp-pd/prof/92-591/Details/page.

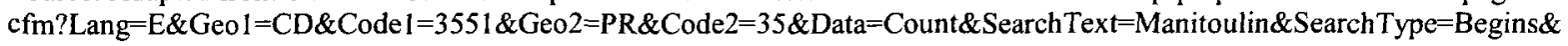
SearchPR $=01 \& B 1=$ All \&Custom $\Rightarrow($ accessed May 12, 2009)

On Manitoulin Island, a higher percentage of the population have some form of apprenticeship or trades-training than is true provincially $(11.5 \% \mathrm{vs} .8 \%)$. When looking 
specifically at females, there is little difference between the proportion of female with apprenticeship and trades-training from Manitoulin Island and that of the province $(\sim 3 \%$ vs. $2.75 \%$ ). There is, however, a larger discrepancy between the proportion of males with apprenticeship and trades-training from Manitoulin Island, and that of the province ( $\sim 8 \% \mathrm{vs.}$ $\sim 5 \%$ ). This illustrates the trend that the males of Manitoulin Island tend to veer towards careers in the trades, rather than pursuing formal educational options, and is comparable to the trends in other rural areas across Canada (see Corbett, 2001). Corbett argues that this trend can be explained by the high amount of cultural capital, in the form of skills and trades, that tend to exist in rural areas and are usually passed down to the males in the community, often via apprenticeships.

\section{Income}

As is illustrated in Table 1.2, the median household income on the Island is significantly lower than that of the province $(\$ 39,645$ vs. $\$ 60,455)$. As will be discussed below, low income has been attributed to the lower postsecondary participation rates of youth from both rural and urban areas (Bushnell, 1999). Thus, it is no surprise given the significantly lower median income of the Island compared to the province, that its educational attainment levels would also be lower.

Table 1.2: Median Income Distribution of Persons 15 Years of Age and Over

\begin{tabular}{|c|c|c|c|c|c|c|}
\hline & \multicolumn{3}{|c|}{ Manitoulin (Census division) } & \multicolumn{3}{|c|}{ Ontario (Province) } \\
\hline Characteristic & Total & Male & Female & Total & Male & Female \\
\hline Median income - Persons 15 years and over $(\$)$ & 19,894 & 24,589 & 16,991 & 27,258 & 34,454 & 21,669 \\
\hline $\begin{array}{l}\text { Median income in } 2005 \text { - All private } \\
\text { households }(\$)\end{array}$ & 39,645 & NA & NA & 60,455 & NA & NA \\
\hline
\end{tabular}




\section{Economy}

As is the case in most rural communities, Manitoulin Island's economy has traditionally been resource-based; centred on farming, fishing and lumbering. However, the Island also has a long tradition of tourism (Pearen, 2001) and now the majority of its commerce focuses on rural vacationing and tourism. As can be seen in Table 1.3, the largest proportion of the district's labour force can be found in "sales and services occupations" (23\%). The largest proportion of women on Manitoulin Island also happen to be employed in this sector (15\%). These sales and services jobs are primarily related to local tourism businesses, such as camp-grounds, local restaurants, bed and breakfasts, souvenir and Aboriginal craft shops, golf courses, realtors, marinas and hunting and fishing lodges (LAMBAC, 2006). However, the "trades, transport and equipment operators and related occupations" is also a major field of labour employment, employing $19 \%$ of the population; with the majority of the jobs held by males (18\%).

Table 1.3: Distribution of Labour Force 15 years of age and over and over by Field of Occupation

\begin{tabular}{|c|c|c|c|c|c|c|}
\hline \multirow[b]{2}{*}{ Characteristics } & \multicolumn{3}{|c|}{ Manitoulin (Census division) } & \multicolumn{3}{|c|}{ Ontario (Province) } \\
\hline & Total & Male & Female & Total & Male & Female \\
\hline Unemployment rate & 10.4 & 10.0 & 11.2 & 6.4 & 6.0 & 6.8 \\
\hline Total experienced labour force 15 years and over & 100.0 & 52.3 & 47.8 & 100.0 & 52.3 & 47.7 \\
\hline A Management occupations & 9.7 & 5.5 & 4.2 & 10.3 & 6.5 & 3.8 \\
\hline B Business; finance and administration occupations & 13.6 & 3.6 & 10.1 & 18.6 & 5.6 & 13.0 \\
\hline C Natural and applied sciences and related occupations & 2.7 & 2.5 & 0.2 & 7.0 & 5.4 & 1.6 \\
\hline D Health occupations & 8.8 & 2.5 & 6.2 & 5.3 & 1.0 & 4.2 \\
\hline $\begin{array}{l}\text { E Occupations in social science; education; government } \\
\text { Service and religion }\end{array}$ & 10.9 & 3.1 & 7.9 & 8.4 & 2.7 & 5.7 \\
\hline F Occupations in art; culture; recreation and sport & 2.1 & 1.0 & 1.0 & 3.1 & 1.4 & 1.7 \\
\hline G Sales and service occupations & 23.2 & 7.8 & 15.3 & 23.5 & 10.2 & 13.4 \\
\hline $\begin{array}{l}\text { H Trades; transport and equipment operators and related } \\
\text { Occupations }\end{array}$ & 19.1 & 17.9 & 1.1 & 14.1 & 13.1 & 1.0 \\
\hline I Occupations unique to primary industry & 6.9 & 6.1 & 0.8 & 2.6 & 1.9 & 0.6 \\
\hline $\begin{array}{l}\mathrm{J} \text { Occupations unique to processing; manufacturing and } \\
\text { Utilities }\end{array}$ & 2.9 & 2.3 & 0.7 & 7.2 & 4.6 & 2.6 \\
\hline
\end{tabular}

Source: Statistics Canada < http://www12.statcan.ca/census-recensement/2006/dp-pd/prof/92-591/Details/page.cfm?Lang=E \&Geo1 $=$ CD\&Codel $=3551 \&$ Geo2 $=$ PR\&Code2 $=35 \&$ Data $=$ Count\&Search Text $=$ Manitoulin\&SearchType $=$ Begins\&SearchPR $=01$ $\& B 1=$ Labour \&Custom $=>($ accessed May 13,2009$)$. 
Furthermore, this occupational sector employs the greatest proportion of males in the district. Many of these jobs are as truck drivers for Manitoulin Transport, heavy equipment operators for Noble Lumber and the Northern Natural Stone quarry, or as tradesmen in the many local construction, electrical, and pumping and heating companies (LAMBAC, 2006). Since this field is the largest employer of men on the Island, it is no wonder that such a high proportion of males have obtained an apprenticeship or achieved trades certification.

\section{Why Manitoulin as a Research Site?}

Given the remoteness of Manitoulin Island, but also because of year round access, the Island is an ideal location to explore the effects of place on rural youth's educational and occupational choices. Manitoulin Island is an area with an economy centred on primary resource industries and tourism. It also experiences the out-migration of its youth, and has a low postsecondary participation rate, particularly in relation to males, and specifically at the university level. Thus, exploring why these rural youth make the choices they do, while still acknowledging the circumstances around which these choices are made can provide valuable insights for the community. In addition, there may be parallels with rural youth in similar areas.

There are some unique aspects to focusing on Manitoulin Island as a study area. Firstly, Manitoulin Island is a remote rural area - only 8 percent of the Canadian population is identified as being a remote rural area (LAMBAC, 2006). In addition, Manitoulin Island is beyond a reasonable commuting distance for attendance at a university. Although the campuses of Cambrian College, and a First Nations college are found on Manitoulin Island, the programs they offer are focused on Adult education. The list of postsecondary programs they do offer is short and limited, as is the list of jobs related to these programs. As a result, these postsecondary education choices are not appealing to the majority of students in the area. Therefore, youth from 
Manitoulin Island must leave their home, family, friends, and community and move elsewhere to attain a postsecondary education. Geography, as defined as distance, is believed to be a determining factor when it relates to educational and occupational choices, but it is often overlooked. Although, many studies identify geography as a factor, researchers claim that the financial and social costs related to leaving one's community to attend a postsecondary institution are what most influence young peoples' choices of whether or not attend, and not distance itself (Frenette, 2002). Therefore, Manitoulin Island is ideal for conducting research which seeks to identify the geographical importance of rural youths' educational choices.

Another reason why Manitoulin Island makes an interesting research location is because it $i s$ an island, and therefore, isolated physically from the mainland. Geography in terms of space and place, in addition to the physical distance mentioned above, is also an important element of this study. Therefore focusing the study on a place that is physically isolated from other locations allows for the study of identity construction in relation to being isolated from more urban areas, as well as mainstream society. The concept of "island mentality" is not a new concept by any means. Using this term to guide my investigation, this thesis assumes that the youth of Manitoulin Island hold different values and beliefs, specifically in relation to the importance of family, community, and thus education, than those held by youth in more urban areas. Although, comparing the social-spatial identities of the youth of Manitoulin Island to youth in an urban area is beyond the scope of this study, this study does seek to explore the social spatial identities of rural island high school students, and use these values and beliefs to understand why these students choose to leave their community.

Manitoulin Island, despite the fact that it is a rural, island region, located in northern Ontario, has many accessible services for its residents. Firstly, most of the larger towns on 
Manitoulin Island have access to high speed internet. This means that information can be easily accessed. Consequently, the effects of living in a rural island community are likely less significant than they were twenty years ago. Secondly, the majority of the population does live within a two-hour drive to The Greater City of Sudbury, and access to major shopping malls, and services. Therefore, youth are not as sheltered from the diversity of educational and career options as they might be. In addition, media including film and television have been important in forming and influencing "island mentality". This knowledge is yet another important source of information which influences rural youths' understanding of other places, and therefore influence their choices regarding leaving their community, and/or pursuing a postsecondary education. All of the above could influence the effects of place, and its role in forming rural youth's values and beliefs, specifically towards higher education. 


\section{Chapter Two: Theory}

\section{Introduction:}

A 15 year old boy sits at the back of a classroom fiddling with his pen. He is wearing faded blue jeans and baggy, well worn t-shirt. His hair is long and shaggy. His fellow classmates have finished their worksheets and are working on their science projects in groups. The teacher sees that the boy's notebook is closed and he is not working, but says nothing and continues to make her way around to the other students; providing encouragement and feedback as she does. The boy continues to do nothing as the end of class draws near.

Two 17 year old girls walk out of school together, chatting. They are talking about how much fun they are going to have next year when they go off to university together. As they reach the parking lot, they hug and then part. They walk and greet their parents who are waiting for them in their cars. The first thing that both of the girls' parents ask is, "How did you do on your English essay?" One of the girls reports that she got an A, and her parents are pleased. The other girl reports that she did not do so well, revealing that she only got a B minus. Her parents are encouraging, stating that they will help with the next one so that she keeps her average up. Both families continue to discuss their day, as they make their way home.

A family of five sit around a table eating dinner. The two younger children are sitting next to each other, arguing about which video game they are going to play when they finished eating. The mother is busy cleaning up milk, which was spilled during the excitement of the youngsters' discussion. At the other end of the table, the older son, who is about 16, is talking with his father who has just offered him a summer job at the garage where he works. His father informs him that this could lead him into a career someday, if he works hard. The boy is appreciative of the opportunity. They continue to talk about the detail of the job, as they finish their dinner.

Above are three vignettes of contemporary life of youth in North America. Although

these vignettes are fictional, they are an agglomeration of the true life occurrences that I have observed while at Manitoulin Secondary School and during my time as a high school student, volunteer, and student-teacher. In addition, they are informed by empirical research as will be indicated below. According to Mitchell et al. (2004, p1), "at the most fundamental level, social reproduction is about how we live". Thus, I start this chapter with these three scenarios and refer back to them throughout this chapter. More specifically, I use them to illustrate how different 
spaces, places and social interactions, combined with various forms of capital, shape and reinforce people's values, specifically young peoples' views about the importance of education and educational attainment.

What is missing from the above vignettes is a significant dimension to both life and the focus of this study - place. Places have long since been recognised as spaces of identity construction, and for young people, various places and spaces are instrumental in constructing and constraining both dreams and social practices (Aitken, 2001). Embedding any of the above vignettes into either a rural or urban setting changes its context, painting a different picture of the values that the youth in these scenarios hold. The scenario of the two girls discussing their postsecondary plans, for example, illustrates this point. If this scenario were to take place in a rural setting, these two girls could be discussing many aspects to their future educational paths. For them, pursuing a university education would likely mean leaving home and their community, as well as families and friends and living in a foreign urban environment (Frenette, 2002; 2003). For these two girls, a rural environment introduces many unfamiliar and likely daunting factors that they must deal with, in addition to making the choices of where to pursue their university studies. However, if this scenario were to take place in an urban area, these two girls would not have the same concerns about leaving home to attend university. Since most major urban areas in Canada are serviced by one or more postsecondary institutions, these two girls could choose to attend university locally. Therefore, they would not necessarily have to deal with the same issues of leaving family and friends, nor would they necessarily have the same concerns about moving to a foreign place, or living on their own for the first time (Frenette, 2002; 2003).

The setting change can alter one's values towards higher education, as well as one's values towards a place within a community and within society, and the dreams and realities one 
can imagine for oneself and for one's future. Again, examining the scenario of the girls walking, if they were from a rural area, these two girls could be discussing their futures in a very positive light, realising that they were on the path that few from their community have taken. They may also be sharing how nervous they are about moving away from home, and leaving almost everyone they know behind. They could be discussing their future career trajectories of becoming journalists or pharmacists. They could also be sharing their wishes to return with their degrees to start their careers or new lifestyles, or to remain in the city, enjoying the services these urban places have to offer. However, if these girls were from an urban environment, they may feel differently about attending university. They might feel less anxious about attending university since many of their friends might be attending the local university as well. They could be discussing their program choices; perhaps one of the girls wants to take Modern Languages so that she can be an interpreter and travel the world; the other explaining that she wants to be an architect and design homes like the ones in their subdivision. Coming from a rural or urban area can influence these youth's feelings towards higher education. It can affect their comfort level with attending university, and where. It can also influence what type of program they pursue or career path they wish to follow. It can even influence where these youth decide to settle once they finish their educations.

This study recognizes the importance of locality, specifically rurality, on secondary school students' perceptions, expectations and attainments of a postsecondary education. Combined with various forms of capital, which often contribute to one's socio-economic status, students negotiate their roles and places in society, often reproducing social positions and structures. This "geographies of practice" approach, allows for the analysis of place, in the construct of "habitus" which young people use to make the best possible decisions. These 
decisions are often based on what they believe to be a limited array of available options to them (Painter, 2000).

Taking such an approach, which focuses on the influence of place on students' choices, is not a simple task. Rurality has not only been linked to socioeconomic status in studies, it is often a major indicator of socioeconomic status, since rural communities tend to be areas with lower level of income, education, employment, etc, compared to provincial, and national levels (Bushnell, 1999). Yet, given that most students have to leave their communities to pursue higher education, there are both emotional and economic costs involved in the decision-making process for these young people. This thesis argues that place is an important aspect in the educational decision-making of rural youth, and as such, needs to be investigated in order to fully understand why some young people pursue a postsecondary education, while others do not.

\section{Outline}

The goal of this chapter is to establish the theoretical framework for this thesis. In this chapter, I review three bodies of scholarly literature that explore educational attainment, locality (specifically rurality), and youth geographies as they pertain to mobility. The first section begins with an outline of Bourdieu's Theory of Practice and highlights how Bourdieu's concepts of habitus, and cultural and symbolic capital can be used as a lens in order to understand the socialspatial relationships that affect rural youth's choices about postsecondary education.

The next section of this chapter reviews the empirical research about educational attainment, specifically in Canada. As will be highlighted, socioeconomic status and location, especially rurality, have been identified in many studies as being significant indicators of lower postsecondary participation (Glendinning, 2003). However, few studies have sought to explain the role of localities in youths' educational decision-making. 
An important aspect of studying education in relation to rural communities is the equally important discussion of youth migration, specifically out-migration of youth from rural communities. Thus, the final section of this chapter reviews the literature on migration, highlighting what others have identified as important features affecting youth and their choices to leave or remain within their rural communities. Here I argue that youths' educational choices, and thus choices to stay or leave, are influenced by the same social processes which youth mobility literature has identified as affecting youths' sense of belonging to their community.

\section{A Theory of Practice}

Pierre Bourdieu's theoretical approach, including his concept of the "habitus", attempts to transcend the conceptual dichotomies of subjectivism and objectivism (Painter, 2000), meaning that his theory attempts to find a balance between internal choices and external forces. In his book Learning to Leave, Michael Corbett determines that "[w]hat Bourdieu calls the 'logic of practice' is the situated decision-making that operates in particular circumstances. Rather than being forced by structural constraints... individuals make the decisions they do on the basis of a practical assessment of their life chances and 'reasonable' options" (Corbett, 2007a, p 45). In the case of Corbett's study, this means that young people see a range of different educational and career choices before them, but tend to gravitate towards those choices that are most "sensible", "coherent" and "convenient", given their own assessment of their chance of success (Bourdieu, 1990; Corbett, 2007a). However, as Corbett elaborates, "in order to understand how Bourdieu's practical logic works, social researchers are required to understand the context in which action happens as well as the creative way that agents 'play their cards', given the affordances of that context" (2007a, p 45). Thus, it is important to target youth who are in the midst of making these important decisions, and investigate their personal reasons for making the choices they do. 


\section{Habitus}

The concept of the "habitus" is central to Bourdieu's theory of practice. Habitus, as defined by Bourdieu (1977), is a:

"system of durable, transposable dispositions, structured structures predisposed to function as structuring structures, that is, as principles of the generation and structuring of practices and representations which can be objectively 'regulated' and 'regular' without in any way being the product of obedience to rules, objectively adapted to their goals without presupposing a conscious aiming at ends or an express mastery of the operations necessary to attain them and, being all this, collectively orchestrated without being the product of the orchestrating action of a conductor" ( $p$ 72).

A clearer explanation of Bourdieu's concept of Habitus comes from Reed-Danahay (2005) who describes habitus as:
"an internalized, embodied disposition towards the world. It comes into being through inculcation in early childhood, which is not a process of deliberate, formal teaching and learning but, rather, one associated with immersion in a particular socio-cultural milieu - the family and household. Through observation and listening, the child internalizes 'proper' ways of looking at the world, ways of moving (bodily habits), and ways of acting. Children, thus, acquire 'cultural capital' associated with their habitus" (pg 46).

Thus, this system of embodied dispositions generates practice in "accordance with the structural principles of the social world" (Nash, 1990, p 432). These dispositions generate practices, perceptions and attitudes which are not consciously co-ordinated, but are second nature to the individuals (Painter, 2000). These dispositions are structured because they reflect the social conditions within which they were developed. Thus, "similarities and differences that characterize the social conditions of existence of individuals will be reflected in the habitus, which may be relatively homogeneous across individuals from similar backgrounds" (Painter, $2000, \mathrm{p} 243$ ). In addition, structural dispositions can be durable, in the sense that they are ingrained in the body and remain throughout an individual's lifetime, as well as generative and transposable, in that they are capable of generating a variety of practices and perceptions in fields 
outside those where the original disposition was formed (Painter, 2000; Hillier and Rooksby, 2002).

\section{Capital}

One of Bourdieu's most widely adopted concepts is that of "capital". This concept is not only used in economic terms, but may also be applicable to a variety of other resources including knowledge and status. Although Bourdieu distinguishes between a range of forms of capital, four forms seem to be most important: 1. economic capital (material wealth), 2. social capital (power and resources related to individual and group social networks and contacts), 3. cultural capital (the knowledge and skills acquired from birth and through education) and 4. symbolic capital (representation of other forms of capital symbolically) (Painter, 2000). In the context of the topic at hand, guided by their inculcated predispositions, youth use these various forms of capital either in association with their habitus, or in various fields, to make "sensible" decisions about their educational and career paths.

Various forms of capital, including economic, but more specifically social and cultural capital, have been linked to social reproduction (Aitken, 2000; Corbett, 2007a). As will be highlighted below, economic capital has been identified as the most significant form of capital influencing Canadian youths' decision-making towards higher education (Looker and Andres, 2001; Corbett, 2005; 2007a; 2007b). However, the effects of economic capital are also related to the importance that youth place on other forms of capital, specifically social and cultural, while making important education and career decisions (Ainsworth, 2002; Corbett, 2005). It should be noted here that cultural and social capital are forms of knowledge that are not necessarily tied to formal education, but are derived from local contexts, and can directly impact economic 
practices (Aitken, 2000). Thus, not only does place matter in terms of where young people grow up, but it is also significant in terms of the people in the community, and how this relationship in turn influences the formation of young people's ideologies about where they will go, if they even want to leave their home communities or go elsewhere. For example, if we take a look at the scenario of the young man sitting in class fiddling with his pencil, we can see how capital can influence one's decision-making and attitudes towards school, and continuing on to postsecondary studies. Despite the fact that his family may have money, if neither of his parents pursued a postsecondary education, or if no one in his immediate family attained a postsecondary education, he is less likely to feel that earning a postsecondary education is necessary for him, or even attainable. In addition, since we see that he is not being supported by his teacher, we can assume that this young man is not receiving any form of social support or encouragement from his teachers. He is not receiving any messages that he can do well in school, or should work towards a postsecondary education. Thus, despite the possibility that he might be able to afford a postsecondary education, this young man might make the choice not to finish high school, or pursue postsecondary studies. However, if this young man does not have money to pay for schooling, he may already be discouraged from making a choice to attend a postsecondary institution. Therefore, despite the attempts of teachers in the past to encourage and support this young man, he may have already made his choice and may choose to ignore the efforts of others, blocking the transference of capital.

The importance young people place on other forms of capital within their social worlds will influence the emphasis on the importance of place (where they want to be, and with whom), the importance of people in that place, as well as their place within society. All of these factors influence their choices to leave the community or to pursue a postsecondary education. For 
example, if we take a look at the scenario of the young man talking with his father. As we see in this scene, the young man is very excited about the prospect of working with his father.

Depending on the job, the transfer of cultural capital to this young man could mean more to him than pursuing postsecondary studies or even finishing high school. Therefore, he may be just as happy staying in the community, being near family and learning a valued trade through an apprenticeship, instead of leaving his home, family and friends, and going off to an unfamiliar place to pursue a postsecondary education (Corbett, 2004; 2005). However, if this young man was not excited about the prospect of doing what his father does for a living, he may make the choice to leave the community to obtain a postsecondary education.

\section{Social and Cultural Capital}

Cultural capital consists of a "symbolic repertoire, the meaning of which is learned and used by members of particular social networks" (Aitken, 2000, p 136). This means that cultural capital represents "ways of talking, acting, modes of style, moving, socializing, forms of knowledge, language practices and values" (McLaren 1989, p 190). On the one hand, social capital depends on the reciprocal relations between individuals within a group (Aitken, 2000).

Social capital does not arise from individuals but from the relations between individuals because it involves reciprocity; thus, the more reciprocal the relationship is, the more valuable the resource. On the other hand, social capital does have a shelf life, and if it is not used, it may diminish as a resource (Aiken, 2000; Coleman, 1990, Putnam, 1993).

Fernández Kelly (1994) states that the form and effects of both social and cultural capital are defined by local geographies (Aitken, 2000). She argues the following: 
"Because people derive their knowledge from the locations where they live, they also expect that which is probable in their nearby environments, and they recognize as reality that which is defined as such by members of their social network occupying proximate spheres of intimacy" (Fernández Kelly 1994, 89).

Therefore, places are important components of social reproduction. In the case of rural areas, place is an important element in the formation of both values and beliefs about postsecondary education, and in turn, rural youths' choices to leave their community to pursue higher education, or not. Furthermore, in terms of rural youth, they aspire to what they see around them, and therefore their career and educational goals often reflect their local environment (Looker and Andres, 2001).

Aitken argues that "there are no deterministic relationships between social and cultural capital, with the former made up by social relations that comprise a network and the latter comprising the dispositions and habits acquired through socialization" (2000, p 138). What is key to both forms of capital is that they represent both actual and potential resources that an individual or group can mobilize through their membership in various groups (Aitken, 2000). However, as Aitken (2000) points out, one of the most important limitations on the formation of both social and cultural capital is geographic location. In other words, these forms of capital "encompass notions of proximity and access, and certain norms of inclusion and exclusion" (Aitken, 2000, p 138). Both social and cultural capital are embedded in a person's social networks, and often result in the reproduction of different experiences and expectations. Therefore, social reproduction may not actually result in the reproduction of specific social positioning, but reproduce and create new social positions based on common beliefs and understandings held by others within one's social network. Just because the majority of the members of a community do not have a postsecondary education, for example, does not mean that the people or youth in the community do not see a value in higher education, or wish 
academic success for their own children. However, how one uses their capital and social networks, and therefore whether or not they decide to pursue postsecondary studies, can be influenced by where they grow up, if they have access to all forms of capital, actual or potential, and if they know how to mobilize these resources to help them pursue their dreams.

\section{Habitus as Sense of Place}

Bourdieu's theory of practice is not commonly used in human geography. Painter (2000) argues that this is due to the fact that Bourdieu's way of thinking is expressed in such a dense and difficult prose that incorporating it within a research context is a daunting task. However, Bourdieu's ideas do hold the promise of transcending many of the divisions in social-scientific and human-geographical thinking (Painter, 2000). In fact, as the authors in Habitus: A Sense of Place illustrate, the concept of habitus can be used as a lens for exploring individuals' sense of place in a given context, whether that be within a community, within a school, or within a specific political or social situation. Using this lens, planners and policy-makers better understand groups' and individuals' daily lives and identities and how these may influence the choices made at work, home, and play. By better understanding one's sense of place within a given context (or "field" as coined by Bourdieu), the people in power might be better able to serve the interests and predict the reactions of those in question. In the case of rural youth and their educational decision-making, by adopting habitus as a lens, I am therefore trying to understand what factors influence the choices they make. However, I am also interested in how various rural youths' identities and daily experiences influence those choices, given the various forms of capital they have at their disposal and the ways they negotiate and make the choices they make, specifically as they relate to pursuing a postsecondary education. In other words, I believe that youth are influenced by the social-spatial context in which they are raised, the places 
they are exposed to, and the capital that is passed down to them by their family and fellow community members (Ainsworth, 2002; Corbett, 2004; 2007a; 2007b; Brooks, 2002). These factors shape their view of their place within the community, and within the school setting, resulting in how they value higher education, and whether or not they leave the community to attain a postsecondary education.

\section{Agency and Practice}

Studies which have focused on the mobility, career and educational choices of youth have often used social reproduction theories such as the theory of practice to explain why some young people leave the community, while others choose to stay (Corbett, 2007a; Lehmann, 2005). Most studies emphasize the capacity of various institutional structures (such as the school) to reinforce social inequalities (Lehmann, 2005). In light of the advancement of children and youth focused studies, researchers have begun to focus more on the concept of youth agency. More specifically, researchers are realising that the role of social structures is neither direct nor entirely deterministic, and that young people can actively shape dimensions of their experiences (Lehmann, 2005; Evans, 2008). The role of agency in school-to-work transition has been seen as "acts of rational choice, resistance, or as reflexive and strategic" (Lehmann, 2005, p 326). Although "Bourdieu's concept of habitus has at times been interpreted as being overly deterministic and incapable of explaining agency or resistance" (Lehmann, 2005, p 331), Bourdieu himself has argued that his work has been misinterpreted. As quoted in Lehmann (2005), Bourdieu states:

Habitus is not the fate that some people read into it. Being the product of history, it is an open system of dispositions that is constantly subjected to experiences, and therefore constantly affected by them in a way that either reinforces or modifies its structures. ... Having said this, I must immediately add that there is a probability, inscribed in the social destiny associated with definite social conditions, that experiences will confirm habitus, 
because most people are statistically bound to encounter circumstances that tend to agree with those that originally fashioned their habitus. ( $\mathrm{p} 331$ ).

So, even though we are more likely to encounter circumstances that agree with those values, beliefs and conditions that reflect our origins, new experiences can modify them, changing our fates. If we look back at the young man sitting in the classroom, fiddling with his pencil, this young man might come from an environment which does not support pursuing a postsecondary education. He may come from a low socioeconomic status family, and/or perhaps have been unsuccessful in school up until this point in his life. The circumstance of his teacher and peers ignoring him, and allowing him to continue on a path which dissuades him away from possibly pursuing higher education, will only reinforce his sense of place in the school system, and society (Bushnell, 1999; Corbett, 2004; Lehmann, 2005; Evans, 2008). However, if one or more of his peers or teachers were to take interest in him, and provide support and encouragement, this could change how he sees himself, his feelings towards school, and his goals for the future. Or if this young man were to become exposed to a career option that excited him, he might be tempted to work harder at school in order to obtain the required education, despite limitations. Thus, there is a component of choice, resulting in a less deterministic interpretation of habitus which is overlooked by Bourdieu's critics.

\section{Educational Attainment}

Scholarly literature, which focuses on the educational attainment and decision-making of youth, has taken a variety of approaches to answer the questions: who goes, who stays and why? Most studies focus on socioeconomic status as an indicator of educational and career directions of youth. Other studies have sought to identify the relationships between educational attainment and factors such as personal and family income, parental education, gender, ethnicity, cultural 
values and family structure (Butlin, 1999; Christofides, et al., 2001; Looker and Andres, 2001; Zhao and de Broucker (2001); Corak, et al., 2003; Finnie et al., 2004; Dorlet, 2005; Finnie et al., 2005). Some research has identified regional differences in educational attainment between rural and urban communities and, as a result, more recent studies have sought to explain or understand these regional differences, especially in terms of rural youths' educational decision-making (James, 2001; Looker and Andres, 2001; Frenette, 2002, 2003; Corbett, 2004; 2005; 2007a). However, according to my research, it is still unclear as to why postsecondary participation of rural youth remains lower than their urban counterparts.

\section{Family Background and Socioeconomic Status}

One of the most widely cited studies of the determinants of postsecondary participation is Butlin's 1999 study. Butlin applies a regression model to assess how socioeconomic status and school-related factors affect participation in postsecondary education in Canada using data from the 1995 School Leavers Follow-up Survey. In this study, and in other Canadian studies since (Butlin, 1999, Christofides, et al., 2001; Looker and Andres, 2001; Frenette, 2002; 2003; Corak, et al., 2003; Finnie et al., 2004; Finnie et al., 2005), socioeconomic status has remained a strong predictor of postsecondary participation, especially at the university level.

Within the category of socioeconomic status, the family background factors that are of most significance in predicting of postsecondary participation are: parental income, and more recently, parental education. In Corak et al., (2003), the authors examined the relationship between family income and participation in postsecondary education over a 15 year period, using the Survey of Consumer Finances (SCF) and the General Social Surveys (GSS) of 1986, 1994, and 2001. Corak's et al. (2003) findings supported the longstanding belief that people from higher income families were more likely to attend university than those from lower income 
families. In general, the study found a more consistent college participation rate among people from all income categories over time. The authors linked this consistent college participation rate across income levels to the increase of tuition fees of Canadian postsecondary institutions over this fifteen year period. Overall, although they did identify a decrease in the gap between high and low income families and their postsecondary participation rate, the authors concluded that family income remained a significant indicator of postsecondary participation. In Frenette's (2007) study, which examines why students from lower income families in rural areas are less likely pursue a postsecondary education, the author found similar results.

According to Butlin (1999), youths with university educated parents tend to be more likely to go to university than those without. These findings have been consistent throughout other Canadian and Australian studies as well (James, 2001; Looker and Andres, 2001). Corak et al. (2001) also identifies parental education as a strong predictor of youth participation in postsecondary education. Since one's level of education is directly tied to one's income level, it has historically been used as a measure of educational attainment, and has long since been identified as one of the most significant indicators of youth educational attainment (Dorlet, 2005). In her 2005 study, Dorlet identifies parental education as a stronger predictor of youth participation in postsecondary education than parental income. Many studies use data on parental education, rather than parental income since young people are more likely to know of their parents' level of education, than their level of income (Finnie et al., 2004; Finnie et al., 2005).

Reasons as to why parental education and parental income are significant indicators of postsecondary participation have been discussed in many studies. It is believed that youth from low income families are unable to afford the increasingly high costs of postsecondary education (Butlin,1999; Corak, et al., 2003). Dorlet's (2005) study dealt with this finding in greater detail, 
discovering that lower income families are often unable to save enough money to pay for postsecondary studies. Also, with increasing tuition fees, student debt is increasing dramatically, which is a further deterrent for many young people. In addition, Dorlet found that there appears to be an expectation by parents that their children should help contribute to their own postsecondary education. With such financial requirements for postsecondary education, Dorlet concludes that it is not surprising that youth participation in postsecondary studies has remained unchanged.

\section{Socioeconomic Status and Geography}

For years, and in many studies across the world, regional disparities have been identified as contributing to who does or does not attain a postsecondary education (Willis, 1977; Butlin, 1999; James, 2001; Looker and Andres, 2001; Frenette, 2002; 2003). Several studies have found that youth from rural areas in Canada are less likely to participate in higher education than their urban counterparts. These findings appear to hold true when controlling for other factors such as parental income and education (Butlin, 1999, Looker and Andres, 2001; Finnie et al. 2002).

Butlin's study (1999) found that high school graduates who had attended school in an urban area were 10 percent more likely to participate in university than those from rural areas; however, they were somewhat (28\%) less likely to participate at the college level compared to students who attend rural high schools (33\%). Finnie's et al. 2005 study which used Statistics Canada's School Leavers and Follow-Up Surveys, also found that students from urban backgrounds were somewhat more likely pursue some level of postsecondary education, and far more likely to go to university than those students with rural backgrounds.

Marc Frenette's $(2002,2003)$ studies explore the role of geography in postsecondary participation by examining the effects of distance on university (2002) and college participation 
(2003). Frenette explores the role of distance, arguing that up until his study the "available evidence on the relationship between geographic distance and post-secondary access [was] scant at best" ( $\mathrm{p} 2$ ), and most studies used a rural/urban variable to measure the effects of distance, not distance as its own measure. Frenette argues that the rural/urban variable is not an accurate measure of the influence of distance on postsecondary participation, particularly university participation, since there are smaller urban areas that are not served by a university. Frenette found that students who lived further away from a university were less likely to attend university. He also found that students from lower income families were more affected by distance than students from higher income families, but that those students with parents with university education themselves were less affected by distance.

In another study in 2003, Frenette found that students who lived outside of commuting distance of a university but within commuting distance of a college were more likely to go to college than university. However, he also found that students who did not live within the commuting distance of either a college or university were less likely to participate in postsecondary studies, and even more unlikely to participate if from a low income family.

\section{Geography and Gender}

Males have historically had the advantage in terms of participation in postsecondary education, but over the past 30 years in Canada, these trends have reversed and now a higher proportion of women participate in postsecondary studies (Butlin, 1999). Lambert et al., (2004) found that women were more likely to pursue a postsecondary education, especially university, and were less likely to drop out compared to males. 
Rurality has been identified as a significant indicator of women's postsecondary participation (Looker and Andres, 2001). Frenette (2002; 2003) found that females were more negatively affected by distance than males. Women were more likely than men to attend university if they lived within commuting distance to a university. If a university was not within commuting distance, but a college was, women were still more likely to attend college than their male counterparts. Frenette also observed that the gap between male and female attendance was greatly reduced with increased distance from school (Frenette, 2002; 2003).

\section{Explaining Why Geography Affects Postsecondary Education}

Although several studies have demonstrated that rural youth have lower educational aspirations and plans when compared to urban youth, this discrepancy has been explained in a variety of ways. Some authors have claimed that "because of differences in rural and non rural labour markets, students from rural communities have limited exposure to a wide range of educational and career opportunities" (Looker and Andres, 2001, p 2). Looker and Andres (2001, p 2) note that "adolescents aspire to what they know or can imagine", therefore, limited exposure can result in depressing educational, and thus, occupational aspirations (also, see James, 2001). Frenette posits that "students in outlying areas simply do not see the benefits from a university education since fewer people hold a degree" (2002, p 23). Frenette, among others, have also argued that rural youth are confronted with the apparent reality that pursuing higher education means moving away from family, home and community. Urban youth have a wider range of postsecondary options, some of which do not require them to leave home. For rural youth, upward mobility requires them to leave their communities, and therefore, those who wish to stay close to home are more likely to have lower educational aspirations and expectations (Looker and Andres, 2001; Frenette, 2002; 2003, Corbett, 2005; 2007a). Leaving home to pursue higher 
education has both financial and emotional costs, which for many rural youth may be too onerous. This seems especially true for rural females, who tend to place more emphasis on social networks (Frenette, 2002).

Frenette (2002) also acknowledges that there are both financial and emotional costs for students living beyond commuting distance from a postsecondary institution. In terms of the financial cost, students living within commuting distance have a clear cost-saving advantage over those students living out-of-commuting distance, since students who live close to a postsecondary institution can choose to stay at home and attend the local school. As for the emotional cost associated with having to leave home to attend a postsecondary institution, Frenette supports Looker and Andres' (2001) argument, stating that students who have to leave home to attend college or university are faced with the choice of having to sever important social networks of family and friends.

\section{Community and Social Capital}

Some of the literature on educational attainment emphasizes the importance of one's family and community on young peoples' values towards higher education. Ainsworth (2002) examined the importance of community (in this case, inner city neighbourhoods in the US) and found that youth who grow up in a community with higher unemployment rates, lower educational attainment levels, and lower socioeconomic status were less likely to do well in school or pursue postsecondary studies. Ainsworth argues that neighbourhood characteristics can influence the collective socialization process by shaping the types of role models that young people are exposed to outside their home environment. In comparison, youth from more advantaged neighbourhoods tended to be more likely to be successful academically, and to pursue higher education. Thus, neighbourhoods or communities where most of the adults have 
steady employment will foster behaviours and attitudes that are conducive to success at both school and work. In other words, children in advantaged neighbourhoods are more likely to value education, adhere to school norms, and work hard because that is what they see modeled for them by the adults in their community (Ainsworth, 2002). In contrast, fewer positive role models in a community mean that children may be less likely to learn important behaviours and attitudes that lead to success in school. Since they lack exposure, these attitudes and behaviours are not reinforced as being useful or desirable (Ainsworth, 2002).

Ainsworth (2002) also identifies social capital in the form of social networks as being an important positive resource, which provides information and opportunities that may be educationally beneficial. He argues that individuals from more disadvantaged neighbourhoods often have smaller social networks than those from more advantaged neighbourhoods. Rural communities often have lower socioeconomic status than more urban areas, and therefore are likely affected by the same socialization process as more disadvantaged inner city neighbourhoods (Ainsworth, 2002).

\section{Mobility, Sense of Place, and Social Capital}

Youth mobility in rural communities is often tied to educational or career goals. Much of the literature which explores youth mobility choices (specifically why some youth choose to leave the community while others choose to stay) examines rural youths' attachment to their community, sense of community, and sense of place. The importance of social and cultural capital on rural youth mobility choices has also been tied to the relationship between individuals and their community members, which include family, peers and neighbours. This is believed to be another significant element influencing rural youth's choices to leave the community, or to stay. 
Some studies have noted the importance of sense of place and place attachment on youth mobility choice by identifying the effect of community involvement on one's sense of belonging and attachment. Hektner (1995) explored mobility choices of rural youth in Scotland. He argues that out-migration of rural youth is due to the increased importance of education and higher paying jobs. In addition, Hektner also found that there was an overall expectation held by community members that youth must leave the community. The "want" to stay in the community is driven by strong ties to home and family, attachment to the community, and the value of social networks (Hektner, 1995). Hektner argues that although socioeconomic status is an important factor influencing rural youths' choices to leave the community and perhaps pursue higher education, that many rural youth may lower their educational aspirations and career goals so that they can remain in their communities.

Sense of place and the importance of social capital have also been identified as being important factors influencing rural youth mobility (Pretty et al., 2003). Jones (1999) found that youth who could identify with their communities were less mobile than rural youth who felt like outsiders or who were not originally from the community. Gledinning et al. (2003) also found that sense of place and sense of self were important dimensions of rural youths' choice to stay or leave the community. Whether rural youth views of the community were healthy, idyllic, and socially inclusive, or isolating, limiting and socially exclusive, influenced their desire to stay or leave the community.

Pretty et al. (2003) also examined sense of place and place attachment and found that those youths who were more involved in the community and the activities it had to offer were more likely to have higher educational and occupational goals. These young people were more likely to choose educational paths and careers which were tied to the community, and were 
therefore less likely to leave their community. They also found that youth who enjoyed rural living and the activities that the community had to offer (e.g. hunting, hiking, fishing, etc.), had a stronger place attachment than those who were less satisfied. Hektner (1995) found that men were much more satisfied with rural life than their female counterparts. Pretty et al. (2003) furthered this conclusion by pointing out in their study that women were considerably less satisfied with life in a rural community than men, claiming that there were fewer activities in rural communities for them to participate in. Glendinning et al., (2003) also found gender differences by citing that men in rural areas are more likely able to use their local knowledge and cultural capital to find stable employment in the community, whereas women tend to be excluded from local industry, and therefore have a greater need to leave the community in search of higher education and better career options. Similar findings were also reported in Corbett's (2007a) study on the youth in a rural Nova Scotia fishing town. Corbett's study found cultural capital to be an important motivator in rural males' choices to stay in the local community and work in the local industry.

\section{Conclusion}

The education, occupation and mobility choices of rural youth are very much influenced by the places where young people grow up. Various forms of capital, spaces, places and social interactions are fundamental in shaping and reinforcing young peoples' values towards attaining a higher education. By adopting the values of family, friends and neighbours, rural youth make choices which shape their future educational and career paths. By assessing the economic structure of the local community rural youth decide from an early age whether they want to leave the community or not. They also determine the sort of educational and career path they might choose, based on their attachment to their community and social networks. Although 
socioeconomic status is a significant determining factor for rural youths' educational outcomes, (often reproducing social positions and structure), there is a strong geographic component to the educational attainment goals and values of rural youth that is essential to the understanding of why rural youth make the choices they do. Understanding the importance of one's sense of place, sense of community, and attachment to the community is key to determining who goes, who stays and why. 


\section{Chapter Three: Methodology}

\section{Introduction}

According to feminist writings, research is a process where the researcher is central in the production of knowledge (Kobayashi, 2001). During this process, the researcher is responsible for making choices and decisions that mold and shape the design of the study, as well as the knowledge that is produced. Thus, it is important for the research methods to be as transparent as possible (Rose, 1997; Kobayashi, 2001).

Although the goal of any research project is to produce knowledge that can contribute to furthering the understanding of the world around us, it is also a learning process for the researcher, and about the process of the research journey (see Corterill, 1992; Rose, 1997; Kobayashi, 2001; etc.) My research about the perceptions and ambitions of rural high school aged students towards higher education is the result of a series of steps including the development of a research design, the establishment of a pre-fieldwork approach, and the collection and analysis of data. Throughout this study, I played a central role in making decisions with regard to choosing a suitable methodology, selecting participants and determining whose insights were most important to the research questions. Choices were also made about how to enter the community, how to recruit study participants, what data collection tools to use, and how these tools should be used within the context of the study.

In the following chapter, I discuss the methodological choices in this research project. This investigation reveals my direct association with the shaping and production of knowledge about the views and future goals of rural youth. It also demonstrates that other actors, including school gatekeepers, parents, and students themselves, play an important role in shaping the research process. In doing so, this chapter discusses concepts of positionality, reflexivity and 
power, and their importance in the overall research process. This chapter concludes by addressing the research process itself.

\section{Adopting a Suitable Methodology for working with Young People}

"Until recently, children [and young people] have not been a principal focus of academic research" (Barker and Weller, 2003, p 207). A growing body of literature in geography focuses on exploring the 'voices' of children and young people, specifically those from rural areas, influencing academic discussions and understanding of present-day rural societies (Holt, 2004).

Much of the discourse on youth-specific methodologies comes from the writings of feminist researchers (see Valentine, 1999; Barker and Smith, 2001; Valentine et al, 2001; Barker and Weller, 2003; Holt, 2004; Hemming, 2007; Langevang, 2007). A great deal of research dealing with younger people has been "criticized for conceptualizing children [and young people] as incompetent, unreliable and incomplete, as mere objects to be studied" (Barker and Weller, 2003, p 208), and that adultist assumptions have underpinned much of the academic research on children and youth within the social sciences (Valentine, 1999). Current feminist approaches are moving away from the tendency to explore children and youth's worlds and experiences through accounts supplied by 'adult proxies', such as parents or teachers (Valentine, 1999). Since young peoples' values and perspectives on their experiences may differ from those of adults, and since young people create their own social worlds and relationships separate from adults, adults can only ever have a partial or fragmented understanding of young people's lives. Thus, critics argue that only children and youth can provide researchers with a valid account of their lives (Valentine, 1999). As a result, researchers are attempting to give young people the opportunity to speak for themselves in the research (Valentine, 1999; Barker and Weller, 2003; Holt, 2004). 
This study considers the methodological literature involving research with young people and draws on post-structural/feminist theory to conduct qualitative research with youth using questionnaires, semi-structured interviews, and participatory observation. This multiple method approach is better "able to capture the complexity and variety of young people's lives in and through space and time" (Langevang, 2007, p 272). Although most current literature utilizing methodologies specific to children and youth suggests using active or participatory research (and incorporating tools like disposable cameras, art and craft activities, journal entries), I chose not to follow these models mainly because of the time constraints driven by conducting research in a school so close to the end of the school year.

Even though adultist methods such as one-on-one interviews and questionnaires have been identified as being inappropriate and intimidating when dealing with youth, "[c]hildren particularly teenagers - hanker after being identified as 'grown up' and respond well to being treated as adults" (Valentine, 1999, p 150). Therefore, in some circumstances using more adultist methods may in fact be a suitable approach for gathering information from youth. According to Valentine (1999) it is often not so much the method that determines whether the research is adultist or not, but the way that it is implemented and what role the researcher assumes within the context of the research in terms of power and superiority.

I attempted to adopt a 'least adult' role and attempted to put aside the 'trappings of power afforded by age" (Valentine, 1999, p 150) when interviewing and interacting with the youth participants in this study. Since the participants were teenagers and the age difference between myself and the research participants was minimal, this approach seemed to be most suitable. By adopting a reflective approach through the research process, I was able to acknowledge and 
address many ethical questions that arose with respect to issues of positionality, subjectivity and power.

\section{Positionality}

Before I continue in this chapter, allow me to take a step back and set the context of this study and discuss my role in the research, specifically in deciding on the research question, location and focus. Feminist methodological writings acknowledge that "all knowledge is produced in specific circumstances and that those circumstances shape it in some way" (Rose, 1997, p 305). Recognizing that all knowledge is situated in the specific context it was produced requires the researchers to be as transparent as possible about their own 'position' within the research context, and adopt a reflexive approach which addresses notions of neutrality and universality (Rose, 1997).

"It is my location—as a classed, raced and gendered being, as a member of a particular social group, and my social position in the hierarchies of power in the academy-that is important (McDowell, 1997, p181).

Consequently, using the concept of positionality as a tool to reflect upon my place within the research context, I will examine the questions: "Where do I, the researcher, position myself within the context of the research process? Where do I stand in the multiple intersections of identity, and how does my identity influence the research process? How do my values and past experiences influence the research process? How will this affect how I represent the experiences of others?

\section{Locating Myself}

I was born and raised in a little community outside Sudbury, Ontario. My home was located on a dirt road, among three others. Earlier in my childhood my family had owned a small 
hobby farm, but as my family grew in size, this became less viable economically and soon, the empty barn was the only reminder that there were once animals grazing in the backyard. I am one of five children in a two parent family. My mother was a stay-at-home mom, while my father was a retired auto-body repair man who injured himself on the job, and consequently relied on a tiny workman's compensation cheque, subsidized by social assistance, to provide for his family. His income was below the low income cut-off line for a one-person household, but somehow my parents always managed to pay our bills and put food on the table. Neither one of my parents had any formal education. My mother, due to difficult circumstances at home, never finished grade eight. Although my father did gain informal training as an auto-body apprentice and learned many valuable skills, his education did not advance much into high school before he found himself in the workforce. Under these circumstances, it is no surprise that I am the only member of my family spanning at least three generations to attend a postsecondary institution and receive a university education.

I am now a twenty-five year old woman currently residing in Ottawa, but I still strongly feel that my home is in the region of Greater Sudbury. I started my university education with the goal of becoming a teacher. However, through courses dealing with the sociology of education combined with teaching placements within public schools, I began to wonder about my own education journey. I had questions about people with a background like my own who seemed less likely to do well in school, or attend university. I obtained a degree in education from Laurentian University, but I have never been employed as a teacher. Now, as a Master's student I am studying a topic that I feel very connected to, and it is my own background, place of origin, values and beliefs that have shaped the intimate research question and process. 


\section{Reflexivity}

It is understood that qualitative research with children is not a straightforward process (see Barker and Smith, 2001; Valentine, 1999, Valentine et al, 2001; Barker and Weller, 2003; Holt, 2004; Hemming, 2008). Research with children and youth raise particular ethical issues, due to their socio-spatial marginalization within society. These ethical issues tend to intensify within an institutional context such as a school (Holt, 2004). According to Barker and Smith (2001, p 143) "[r]eflexivity should be adopted at all stages of the research process, locating and deconstructing the positionality of the researcher and the situatedness of geographical knowledge". The following section reflects on my position within the field and the relationship between my role as researcher, and the students and teachers who participated in this study.

\section{Reflecting on My Positionality}

Prior to conducting this research, my connection to Manitoulin Island did not extend much further than an occasional weekend trip to my in-laws' cottage. Most of the people I knew there were retirees who had made seasonal cottages their permanent homes. Thus, I did not know the subjects of the research personally. However, I did feel I could connect well with both the students and the teachers who participated in my study for different reasons. In terms of student participants, despite the age difference between the students and myself, I felt I could connect to them since I have friends who are still in high school. However, I cannot claim to be an accepted 'insider' in the community of students who shared their thoughts and feelings with me during the course of the research. I did not grow up on Manitoulin Island. Due to the high Aboriginal population on the Island, I also knew that some of my participants would come from cultural backgrounds different from my own. I knew that they would have a different way of learning and understanding the world, and sharing that knowledge with others (Jenkins, 2007). Although I 
could use my own background to gain access to some of these students, there would be some students with whom I would be able to connect more easily than others.

In terms of the teachers that I interviewed, I felt that I could connect with them since I too was a qualified teacher and one interested in the topic of student education. Again, however, I could not claim 'insider' status. I was entering the school as a perceived student to conduct research, and not as a teacher. Also, for the most part, I was much younger than most of the teachers on staff and did not have the teaching experience that they had. I used this aspect of my identity to build rapport and recruit teacher participants. However, the level of rapport I established did vary among staff members.

My gender also can be seen as significant in shaping the research. My gender was likely a useful tool in gaining access to the school in general, and definitely useful in gaining access to individual classes for participatory observations and participant recruitment. As Barker and Smith (2001) point out, childcare and education tend to be gendered professions, where more women are employed than men. As such, the introduction of a male into an environment such as a school tends to be more noticeable. Barker and Smith (2001) also found that males had more difficulty negotiating with gatekeepers, requiring more formalities, paperwork, information, and reassurances. Females on the other hand, tend to be less 'noticed' when entering these environments, their presence tends to be less problematic, and they are more easily accepted as an insider. As such, since most of the faculty and staff at Manitoulin Secondary School were female, I found that my presence in the school was easily accepted, and I was quickly welcomed by many of the faculty there as a temporary member of the staff and also accepted by the students. 
Since I was a female researcher, my gender likely helped in gaining parental trust and written consent. My gender also assisted in gaining access to female participants and building rapport with this group of participants, which is partially why female participation was significantly higher than that of males in this study. Being female made it very difficult to recruit male participants.

I used my teaching background to gain access to the school and recruited many of the students by being visible in their classes and acting as an assistant teacher. Therefore I cannot claim to speak as the 'voice' of these young people. In addition, once I was finished collecting my data, I was able to return to my life in Ottawa. Thus, I felt it important to provide an opportunity to share with the research participants, my experiences of pursuing a postsecondary education, and to give something back to these young people.

\section{Methodological Issues and Relations of Power}

According to Barker and Weller, (2003, p 210) "methodological issues are refracted in unique ways in research with children, because of the particular social context of adult-child relationships, and most significantly the unequal power dynamics that constitute these relationships". Therefore, many feminist scholars have identified the:

"potentially exploitative relationship between (older) researchers and (younger) research subjects through the consideration of issues such as confidentiality and consent, access to (potentially vulnerable) groups of young people and the spaces they inhabit, involving research subjects throughout the research process (from development to dissemination) and allowing young people to 'opt in' and 'opt out' of the research (Morris-Roberts, 2001, p 148). 
Thus, it is important to take responsibility for our politics, and be accountable for the subjects of our research and the ways that knowledge is produced (Valentine, 1999; Barker and Smith, 2001; Morris-Roberts, 2001; Barker and Weller, 2003). By adopting this feminist ideology, I attempted to treat the young people I was working with as competent decision-makers and involved them in the research process. I tried to work with research participants, rather than "on" or "for" them, by inviting them to suggest convenient meeting times, giving them blocks of time for returning permission forms, or filling out the questionnaire (Morris-Roberts, 2001). Although it is required for ethics approval, one way of including youth in the research process is by allowing them to "opt in' and 'opt out' of the research at any time (Valentine, 1999; MorrisRoberts, 2001). However, since the research was collected within a school and research subjects were for the most part minors, participants also needed to have parental consent. This necessary permission form undermined the choice to give students the right to "opt in", and likely affected the willingness of students to participate. It was, however, a necessary step when working with youth in this setting.

\section{'Outsider', 'Insider' and 'Between-ness': Gaining Access to Participants}

According to Valentine (1999, p 149) there is an "obvious power imbalance between adults and children in terms of biological age, bodily size, lack of knowledge, experience and social, political and economic status". However, my biological age (24/25), visual appearance (my hair style and use of purple hair extensions; my height, $5^{\prime} 3^{\prime \prime}$ ), body language and performance (i.e. how I acted, where I sat in the classroom, how I sat when talking with students), language use and dress, did not necessarily distinguish me enough to accentuate any power imbalances. In fact, even after being in the school for over a month, I would be mistaken as one of the students by teachers. Close to the end of my visit at Manitoulin Secondary School, I 
was conducting an interview with a female student in the cafeteria during first period and we were approached by the vice principal. He asked us if we had a scheduled spare or if we were supposed to be in class. Only after I had pointed out that I was conducting an interview, did he realize that I was the student researcher in the school.

Sometimes I entered classrooms to recruit students posing as an assistant teacher. Since I used my prior teaching experience to gain access to the school, teachers' classrooms, and to recruit teacher participants, I reinforced my position as an 'outsider' among the students that my research was targeting. I also found myself more welcomed by teachers in the staffroom than I did in the cafeteria among the students, and this also reinforced my status as an 'outsider'. Although it was important to establish an "insider" position among the teachers at Manitoulin Secondary, I found that my experience of being neither a teacher nor a student, put me in an ambiguous third space where I was neither an 'insider' nor an 'outsider', but something in between (Morris-Roberts, 2001; Holts, 2004).

This 'between-ness' provided challenges when defining myself relationally to an 'other', or to anticipate the power relations between myself and research participants. As an adult, I am 'other' to the young people I interviewed, and was frequently powerful. However, these power relations shifted and were context specific (Holt, 2004). For example, when I was recruiting students to participate in my study, I sat in on a grade nine Art class. After the teacher had introduced the lesson, she introduced me and told her students that I would be observing the class. Once the students had begun working on their Art assignments, I began to make my way to the various groups around the classroom. As I approached each group and attempted to enter their social worlds, I realised that I was in a relatively powerless position. These young people were the gatekeepers of their own discussions and groups, and had the power to allow or deny 
me access to participate in their conversations. I found that emphasizing my adultness and teaching background was a hindrance when trying to recruit and establish rapport with these potential young participants.

My position of 'other' in relation to the teacher participants was also interesting. During the teacher interviews, I tended to have more power since I was the one asking the questions and shaping the direction of the interview. However, there were many contexts when I felt relatively powerless. For instance, when entering classes to conduct participant observation and recruitment, or requesting permission to excuse a student from class to be interviewed, the teachers were the gatekeepers and held all the power. At these moments, I was relatively vulnerable to their willingness or unwillingness to assist me in my study. In the context of setting up my interviews with teachers, I granted them the power to decide where, when, and what time the interviews would occur. However, although I attempted to neutralize the power imbalance, as Cotterill (1992) noted, neurtrality is not possible. The balance of power shifted during, and with different interview settings, and there were times during the interviews where I still felt vulnerable, and powerless.

During the course of my research at Manitoulin Secondary School, I interviewed teachers in varying stages of their teaching career, and my experience in interviewing differed with each of them. I found that some of the teachers were easier to build rapport with than others, and that the rapport established prior to the actual interview did not guarantee a rich, descriptive interview once the tape recorder was turned on. I found that age and gender also played a role in my ability to establish an 'insider' identity and to build rapport with the staff at Manitoulin Secondary. Although I was able to connect with a few of the men on staff, for the most part I felt a great divide between myself and them. Also, although I tried to use my Bachelor of Education 
to establish my identity as an 'insider' and build rapport with teachers, since I was an 'outsider' to the school, I felt rather neglected by those on staff who did not want to be bothered with any extra obligations so close to the end of the school year. Although many of the staff members were willing to help and even participate in the study, I found that I was able to establish an 'insider' identity and build great rapport with only two of female staff members. These teachers granted me access to their classes, excused students for interviews and volunteered to be interviewed.

\section{The 'Politics of Access' within Schools}

In addition to the other dimensions of my identity that were emphasised while I was in the field, I entered the school as a student from Carleton University, and a guest within Manitoulin Secondary. I was welcomed by both the Rainbow District School Board, and the Principal to conduct research within Manitoulin Secondary School. This role required me to negotiate access to both the space of the school and the students in order to conduct my research. According to Baker and Weller, (2003, p213)

"[t]he 'politics of access' often requires a lengthy process of negotiation and compromise on the part of the researcher, as they liaise through entire complex networks of gatekeepers before asking a child whether he or she would like to participate".

This process demonstrated to me the power that gatekeepers have in terms of allowing access to children, and how easily the researcher can lose autonomy and control of their research in order to negotiate and address issues around gaining access (Valentine, 1999; Baker and Weller, 2003). This process required that I obtain a police background check, ethics approval from Carleton University, ethics approval from the Rainbow District School Board, access from the principal, assistance from the secretaries, and permission from individual teachers to gain access to their 
classes for participant observation and recruitment. Overall, I was fortunate that the negotiations I made really only limited the time frame of data collection, and I had very little trouble accessing classes for participatory observation, and recruitment. I can likely attribute my success to the fact that I do have a teaching degree, and therefore knew the confines of working in a school, what requests I could expect to be granted, and what would be denied to me. Working with this knowledge, I was able to plan this research study with a general understanding of what to expect. Since none of my requests while in the school were overly demanding, and since I respected all of the people I negotiated with, I was able to complete my data collection with little interference.

I did experience the important role that gatekeepers can play in shaping the research. I found that the secretaries were key gatekeepers to the teachers and students within the school, and although I attempted to visit a class of each of the teacher's at least once during my first days within the school, I was advised and assisted by the secretaries as to which teacher's classrooms and courses I should request to visit and observe. The secretaries were a great help to me while I was in the school collecting my data, but they played an important role in shaping the research by directing me to particular staff members, subjects and grade levels.

The teachers themselves also played a role as gatekeepers. When approached, some teachers welcomed me into their classrooms, but they did not always introduce me to the students when I arrived. Without an introduction to the student body, a rift was created between me and the students, limiting their interest to be participants in the study. Other teachers welcomed me with a brief introduction, but did not endorse any specifics of the research project or my presence, which again did not engender any interest for my study. In contrast however, there were some teachers who welcomed me into their classes and offered to help in any way 
they could. They introduced me and my research to students, and encouraged the participation of their students while I was there as well as during the days leading up to the deadline for permission form submission. These teachers not only assisted in the recruitment of students, but also in the encouragement of particular students to participate in the study, thus shaping the research in more than one way.

Finally, when working with young people, the researcher is often required to negotiate with parents and guardians (Valentine, 1999; Baker and Weller, 2003). However, I found in the case of high school youth that the students were the gatekeepers to their parents. I had to rely on them to bring the permission forms to their parents in the first place, inform parents about the project, and then bring the forms back to school. Although incentives were used, I found that parents were less important gatekeepers to this age group since high school aged youth were more than capable of making the choice to participate or not in the research process on their own. The signed consent form was merely a formality for the ethics process in the study.

\section{The Research Process}

A feminist theoretical approach was chosen since this approach moves away from the tendency to explore children's worlds and experiences through 'adult proxies', and provides young people with the opportunities to speak for themselves (Valentine, 1999; Barker and Weller, 2003; Holt, 2004). Therefore this study sought to give young people the chance to explain for themselves their values and ambitions towards postsecondary education, and the origin of these ideas. Also, since research with children and youth raise particular ethical issues, a reflexive approach was adopted at all stages of the research process, "locating and deconstructing the positionality of the researcher and the situatedness of geographical knowledge" (Barker and Smith, 2001, p 143). Reflexivity offered a means to locate myself in the 
research process, and identify how my actions and choices influenced the construction of information collected during my time in the field. The following section will discuss the research design process itself, reflecting and providing a rationale for the steps taken during the prefieldwork stage and data collection.

\section{Pre-Fieldwork Approach}

Studying the perceptions and ambitions of rural high school students on Manitoulin Island was not an arbitrary decision. I chose Manitoulin Island as a focus for my research for several reasons. Firstly, I was interested in looking at the effects of rurality on higher education. I chose Manitoulin Island since it is a rural area with limited access to postsecondary institutions. Some of the literature focusing on the relationship of rurality and education has been focused on coastal communities in Nova Scotia (Corbett, 2007), and I thought that focusing on an island community in northern Ontario would provide an interesting contrast to the issue and an opportunity to make relevant comparisons. Manitoulin Island, like many rural areas, faces economic and demographic trends similar to Nova Scotia. Geographically, it has been shown that communities in northern Canada, including northern Ontario, tend to have lower educational attainment levels than those in other areas in Canada (Ontario Trillium Foundation, 2007).

\section{Research Focus: Rural High School Students as a Unit of Analysis}

There have been many approaches to the study of educational attainment; however in this research, I wanted to focus particularly on rural youth since they are the people who make the decision to pursue postsecondary studies or not. Consequently, this population is a good source for understanding the perceptions and ambitions as they related to higher education. According to Corbett (2007a, p 774) "the period between grade 8 and grade 10, [is] a crucial time for educational decision making". However, since grade twelve students are the group of students 
actually making the choices of whether or not to pursue postsecondary studies, and/or deciding what to study and where to attend school, it seemed more appropriate to focus on this group of students for this study. Considering what Corbett (2007a) stated about grades eight to ten being an important decision-making periods, I thought it important not to neglect students from younger grade levels. Therefore this study sought to survey and conduct intensive research with a sample of student between grades nine and twelve (those grade levels available at the school). Since the study was focused on rural youth between the ages of 13 and 18 , I had to decide how to gain access to this group of people. Because children and youth spend most of their time at school, and since I have a background in education, it was a logical decision to attempt to conduct my research within a high school setting. Since Manitoulin Island falls under the purview of the Rainbow District School Board, Manitoulin Secondary School was an ideal research location for this study. In addition, I also have connections on Manitoulin Island and therefore knew that finding affordable housing while on the Island collecting data would be possible.

Manitoulin Secondary School is home to about 550 high school students from all across the Island. It is the only public high school on Manitoulin Island serving the entire geographical area of $2,766 \mathrm{~km}^{2}$. The high school is actually located in the centre of the Island, in the township of Central Manitoulin, in the town of M'Chigeeng, previously known as West Bay. Culturally, there is an even distribution of Caucasian and Aboriginal/Metis students at the high school. Most of these students commute to school using the bus service funded by Ontario's Ministry of Education. 


\section{Per-Testing Data Collection Methods}

There are often "concerns about whether younger people have the cognitive, communicative and social skills necessary for providing good quality responses" (Bell, 2007, p146). Before entering the field I conducted pilot interviews with a couple of young people I knew, focusing specifically on the questionnaire. Bell (2007) notes that questions may be problematic even after being tested, but that pre-testing is still a useful and effective way of testing the quality and effectiveness of surveys and questionnaires. One of the most frequently used means of testing questionnaires is known as 'think-aloud'. This technique requires the respondent to verbalize what he/she is thinking as they answer the questions. Using this method, I talked with these youth about the questionnaire and the list of established questions for the oneon-one interviews. Later, I adapted these survey tools based on the feedback.

\section{Entering the Field}

Initial negotiations to access the field began when I contacted the principal of Manitoulin Secondary School in early February 2008. After a short phone interview with the principal, I explained my interest in conducting a study with the youth of Manitoulin Island and my interest in using the school as the research site. I was instructed about the need to contact the Rainbow District School Board and get permission from the board before I would be able to enter the school. I was also informed of the restriction and stipulations of my access to the school and students. These limitations included restricting my presence in the school to the month of May, since June would be set aside for exam review. However, after becoming a temporary member of the school, I was granted additional time in the school to conduct interviews with the teachers during their free time. Another stipulation was that the school would be willing to host my research project as long as it did not interfere with the workload of the staff of Manitoulin 
Secondary School. In other words, teachers and other staff members were under no obligation to assist me in recruiting research participants or promoting the research study. In addition, I was asked to limit my impact on students willing to participate, by trying to minimize the interference of this study on their education. This meant that I was to use student's free time such as lunch and spares, before requesting to excuse students from classes.

I contacted the Rainbow District School Board shortly after speaking with the Principal of Manitoulin Secondary. At this point I was still in the process of writing up my research proposal and finalizing the methodology of the study. One of the Superintendents of Schools at the Rainbow District School Board was my grade eight teacher in one of the boards Schools. I contacted this Superintendent with a summary of the study I wished to conduct and asked about the Rainbow District School Board research and ethics application process. I was informed that I needed to contact the Superintendent of Schools in charge of the approval of research conducted within Rainbow School. I contacted the Superintendent via email and I received a prompt reply, which outlined both an interest to host my research, as well as instructions on the application process.

Carleton University's Ethics Committee reviewed the proposed study according to the guidelines set by the Tri-Council, and granted approval of the study in late April 2008. The Rainbow District School Board then reviewed the application for the proposed study, which included the official letter stating that ethics approval had been granted to the project by Carleton University, and granted me access to the school within a few days. By May $6^{\text {th }}, 2008$, I had spoken to the Principal of Manitoulin Secondary School, and had arranged to begin my field work the following day. 


\section{Initial Recruitment Strategy}

As an outsider to both the community and the school itself, I anticipated that recruitment of students would not be an easy task. After negotiating my access to the school, I knew that I still had to enlist students to participate in the study. I intended on using all available means to promote the research project within the school, including using the PA system to broadcast announcements and reminders about the research project, introducing myself and the research project to individual classes, using participatory observation and my role as a teaching assistant or guest in the classroom to attract participants, and sending home a letter of consent which outlined the research project to parents. In addition, a lottery was used to promote participation of students in the study. Any student who consented to participate in the research study, and filled out the initial questionnaire would have their name entered into a draw to win an iPod Nano, which I bought specifically as an incentive for the study.

From the onset I indicated my interest in talking with any and all of the students attending the school. Participants were recruited based on the timely return of the letter of consent, which had to be signed by their parent or guardian. However, recruitment of students, even with the use of the iPod Nano lottery promotion, proved to be as difficult as I anticipated. Ultimately, the promotion of the research project by key gatekeepers did assist in recruiting 32 students, and I conducted interviews with 30 of the 32 students.

Although, I was able to attract 13 grade twelve students, I was less successful in attracting participants from grades nine, ten and eleven. The majority of students who participated in the study were female, and/or were students enrolled in the University stream (see Appendix A).

In addition to the student participants, I was also able to recruit 11 teachers to participate in the study. These teachers were invited to participate in the research with a letter which was 
administered during my fourth week in the field. Teachers were also invited to participate in the study during interactions and conversations held before and after class, in the staffroom during lunch and after school periods, or even during short interactions in the halls. These interviews were used to provide a context for the students who participated in the study, and to provide insight into the perspectives of rural educators.

\section{Fieldwork Process}

The research took place during the months of May and June of 2008. During this six week period I collected data using participatory observation, questionnaires, and one-on-one semi-structured interviews. The following section outlines each of the these research tools, and their importance to the research process.

\section{Participant Observation}

Participant observation was an ongoing aspect of the research, but it was most important at the beginning of the study when attempting to gain access and recruit participants at Manitoulin Secondary School. Participant observation is a useful tool in qualitative studies with children and youth, since prolonged interaction between the researcher and researchees builds an understanding of their worlds, builds rapport, forms relationships, and gains mutual trust (Langevang, 2007). Thus, I spent the first week and a half of my visit going from classroom to classroom, observing and interacting with students. I also made visits to the cafeteria to try and introduce myself to students, especially those whose classes I was unable to attend. In addition, I attempted to interact with the staff of Manitoulin Secondary School as much as I could, spending time before, after, and occasionally during class, chatting in the staff room, main office, or in the guidance office. 
I found that my presence in the school was essential to recruit students. Participant enrolment was low despite the steps I took to encourage it. I used daily announcements to enlist students in the research study, I provided the incentive of a chance to win an iPod Nano, I distributed information and permission forms to students to bring home and read with their parents, and I requested that teachers remind their classes about the project daily. Using the secretaries as gatekeepers, I attempted to enter classes from every grade level to acquaint myself with students. I observed that only after students got to know me, and talk to me about the study and what their role would be, were they likely to participate, however briefly. For example, I went into a grade ten class on a Monday after the permission forms were sent home. I mingled with the students of the class after their lesson and while they were working on their assignment. Nearing the end of the period, two of the female students I had been talking with requested another copy of the form so that they could participate. They returned their signed forms the next day.

Closer to the deadline for students to return their signed permission forms, I began to revisit some of the classes I had visited during the first few days within the school. At the time I had very few grade 12 student participants, so I revisited a grade 12 classroom to remind students that the deadline was approaching, and to inform them that their group was significantly underrepresented. I also mentioned that I would really appreciate their involvement and informed the students that if they were 18 years of age or over, they could sign their own permission forms. Once these older students found out participation was their choice, and they did not have to involve their parents, over half the class was willing to participate. From this, I concluded that students were reluctant to participate if it meant that their parents had to sign the permission forms. For whatever reason, whether it was because it was too much hassle to bring home the 
permission form, get it signed, and bring it back, or because they were rebelling against the fact that they could not just participate in the study of their own free will, I am unsure. Clearly, however, students who could sign their own permission forms were much more willing to participate and may be related to the desire of these young people to be adults.

The importance of empowering students has been identified by many scholars who work with children (Barker and Weller, 2003; Barker and Smith, 2001; Valentine, 1997; 1999; etc). Allowing young people to opt in or out of the study has been identified as an important way of empowering students. Nevertheless, Valentine (1999) and Barker and Weller (2003) warn against negating the role of the parent in this decision. Had I attempted to propose a study that empowered young people in this way, I would not have been able to gain ethics approval to conduct this research within a school, or gain access to the school. The school boards have a responsibility to protect their students. However, I would argue that most students from grade nine to grade twelve are capable young adults and able to make the decision to participate in a research project such as this (Valentine, 1990). Therefore parental consent undermines this ideology and I believe that had students actually been empowered, more may have been willing to participate.

\section{Survey Information}

Only recently have social researchers come to acknowledge the importance of directly conducting survey research with children and youth rather than collecting evidence through adult proxies (Bell, 2007). While qualitative data is an extremely important component of this study, the collection of quantitative data through the use of a questionnaire was used to provide a valuable glimpse into the unique perspectives of this group of students' social worlds (Bell, 2007). The questionnaire used in this study to collect contextual data about students, consisted 
of 45 questions. These questions were designed and pretested before entering the field in order to identify any problematic questions (see Appendix B). The same young people who helped pretest the questions for the interviews also pre-tested the survey by filling out the questionnaire and providing feedback. We discussed how they interpreted each question, and how I should alter the questions to make them more accessible to young people.

Students were asked to fill out the questionnaire at an initial meeting once they had returned a signed permission form by the end of my second week within the field. It took less than ten minutes for most students to complete. As Bell (2007) points out, questionnaires have been criticized as an inappropriate data collecting tool when working with children and youth. Researchers have expressed "genuine concerns about whether younger people have the cognitive, communicative and social skills necessary for providing good quality responses to survey questions" (Bell, 2007, 146). However, children aged 11 and up are believed to be able to use adult questionnaires with little need of adaptation (Bell, 2007). The questionnaire in this study consisted of simplified, short questions designed with this age group in mind.

Bell (2007) notes that when designing and using surveys, we must acknowledge that "age here represents a shorthand for average cognitive development" (Bell, 2007, p 147). Thus, researchers must use age discriminately since the actual development of any individual child is a product of not only age, but also various inherited and socio-environmental factors (Bell, 2007). In the case of my research, I collected data from two students who were not capable of answering the questions in the questionnaire on their own. I sat with, and read the questionnaire with these students, and also reworded questions for them so that they could complete the questionnaire. However, with above in mind, I decided that I would not use the data collected from these 
students or continue to involve these students in the research, resulting in 30 students being utilized and not 32 as noted.

\section{One-On-One Semi-Structured Interviews}

Interviews are a valuable tool when the research seeks to unravel complicated relationships, or understand a slowly evolving event, and can lead to insight far beyond the researcher's imagination (Hoggart et al, 2002). In this research study in particular, one-on-one interviews were used to identify and understand the intersection between socioeconomic, cultural and geographic factors that influence youths' perceptions, expectations and attainment of a postsecondary education.

The interviews took place after the initial meeting on May 16,2008, and only after the questionnaires were completed. I arranged to conduct interviews with students either at the initial meeting or by setting up interview times with them. Initially, I was only going to conduct semistructured interviews with grade twelve students since this was the group of students who were currently planning their futures after high school, and contemplating postsecondary studies. However, since I did not recruit enough students in each grade to conduct focus groups, I decided to interview all volunteers. In total I interviewed 29 students between May $16^{\text {th }}$ and June $2^{\text {nd }}, 2008$. I was unable to connect with and schedule an interview with the final student participant.

Whenever possible, students were interviewed during their scheduled spare periods during the school day. However, a few grade twelve students, along with students in grades nine, ten and eleven were individually taken from one of their course classes to be interviewed. Students were only removed from classes with their teacher's permission. All interviews began with me introducing myself. I then outlined the goals of the study and a reminder of the 
participant's rights during the research. Each interview was digitally recorded and a semistructured outline was followed. Most of the interviews were conducted in the school cafeteria. I conducted the first few interviews outside since the weather was suitable, but also because I had not been provided with a quiet place to conduct interviews. The first space the staff at Manitoulin Secondary School had provided for me was a rarely used office space across the hall from the main office. The furniture in this space was fairly old and looked as though it had been put together to function as a temporary work area. There were a couple of posters on the wall and door, advertising programs like Crime Stoppers, but that was the extent of the colour in the room. Overall, it was a cold, bleak room, where even I felt uncomfortable. After conducting a few interviews in this room, I was relocated to a back room in the main office which had been originally redecorated to serve as a medical office. The walls had been painted pink and decorated with a green ivy-like design, giving an overall cozy feeling. However, I found that this office separated me and my interviewee too much from the school setting. Within this room, we were not able to hear the bell signalling a change of classes or lunch, and were isolated from the activities of the school and its members. I felt uneasy being so separated from the rest of the school, and felt that my participants would likely feel the same. Thus, I began using the cafeteria to conduct interviews. This was a location where students communicated with one another on a daily basis. Here I could conduct interviews with students in a relatively quiet environment (since interviews were conducted during class time when the cafeteria was relatively quiet). I was also able to establish a comfortable atmosphere suitable for a relaxed conversational interview. I found that the location of the interviews influenced the level of rapport established and it also affected the quality of the answers provided by the interviewee. 
For interviews with teachers, the setting was a location of their choice. Most chose to do the interview in their departmental offices where they felt most comfortable. A couple of interviews were conducted within their empty classrooms or in the staffroom. The interviews conducted in the staffroom were usually interrupted. Since this was a shared space, other teachers often walked in and out while the interview was going on. None of the topics that were spoken about were extremely sensitive, and I advised these participants of their rights and at times even suggested going to other places to finish the interview. None of these teacher participants seemed worried about being overheard by others. Being new to research, and trying at all times to keep the best interest of the research participant in mind, I felt uneasy when people would enter the staffroom. However, this did not seem to be an issue for these participants, and so we continued the interviews. These interruptions were distracting to me, and therefore affected my performance as a researcher and I have no doubt that at least in response to me the quality of information provided by these participants was influenced as well.

\section{Conclusion}

The time spent in the field for this research was a valuable learning process for me and I learned and practiced valuable reflective and communication skills. I learned how to conduct interviews and recruit participants, and I learned the importance of being flexible in the field since things do not always go as planned, and you cannot predict the willingness of people to be a part of a study. By adopting a reflexive approach, I was able to identify the role that I played in shaping the research study and the data collected. I was able to see that my initial choices before entering the field (including the choices of where to conduct the research, who to conduct the research with, and how I would collect the data) played an important role in shaping the study. In addition, I was able to perceive how my choices in the field played an important role in shaping 
the study. Choosing to conduct interviews with all student participants and forgoing the use of focus groups, for example, changed the data collection process, and likely the type of information collected. This reflexive approach also allowed me to see that I was not the only player shaping the research. Other actors, including the secretaries, the teachers, the parents, and the students themselves played important roles as gatekeepers, and influenced who the participants were for this study.

In addition, issues of power, and positionality influenced the research process, and the data collected. As illustrated, there is an obvious power imbalance between adults and children, and young people are often at a disadvantage, having to follow the rules and expectations set by adults. This inequality is heightened in schools where a power balance in favour of authority figures is often seen necessary to maintain order. At the same time, issues of power and power imbalances are directly linked to the positionality of the researcher. Although I attempted to empower students and teacher participants, I often found myself vulnerable in terms of my own changing identity as student, qualified teacher, and researcher. Since my identity was a social construct and would change from 'insider' to 'outsider', (or somewhere in between), this affected the recruitment, as well as the interview process of all participants. I was also vulnerable to the power of gatekeepers and the politics of gaining access to the children, and had to be careful in terms of maintaining autonomy and control of the research itself. Overall, reflexivity allowed the identification of the importance of power and positionality in the research which would not have been identified otherwise. 


\section{Chapter Four: Analysis and Discussion}

\section{Introduction}

"I don't know... The big thing is to just get off the Island. Everyone wants to leave I think." Willow - Grade 12 student)

"Well, in today's society, you have to have a postsecondary education to get a good job. Like, my dad didn't go to postsecondary, and like, he's living a really comfortable life. But, I mean, to get those kind of jobs, you don't get them anymore. You actually need a better education to make a better living, I guess." (Cleo-Grade 9 student)

"[It's] a ticket to always having some kind of job. Even if it's not quite the one you wanted, at least you will always have a job. While, those who are uneducated, if their business fails, they don't have anything to fall back on. If they lose their job at Foodland, then they're stuck. They don't have anything else." (Phoebe- Grade 12 student)

The above quotations illustrate a range of beliefs about the importance of postsecondary education, as expressed during the semi-structured interviews I conducted with young people. These quotations exemplify a shared understanding that postsecondary education is a necessity in today's society. Consistent with earlier research on postsecondary education, interviewees identified that distance, cost, and family were all factors that affected their choices, especially in light of the necessity to leave home. Many students expressed that their beliefs were also shared by family, friends and the larger community.

In this chapter, I present my research findings based on the reports of a group of rural high school students from Manitoulin Island, who intend to leave the Island to attend a postsecondary institution after high school. As this chapter will illustrate, the formation of the perceptions and ambitions of these rural high school students towards higher education, is largely social-spatial in origin. Using direct quotations from the interviews and pseudonym names for all participants, this chapter will discuss these findings in relation to the literature, revealing that the role of place has indeed been overlooked in the literature. 
I begin this chapter with an account of the steps I took to analyze the data collected from the semi-structured interviews, participant observation, and questionnaire, and the process I undertook in order to organize data to reveal thematic patterns. I include this information to address issues of reliability, credibility and rigour. Studies that utilize qualitative research methods are often criticized for not providing significant detail on how data are analyzed (Baxter and Eyles, 1997). Although many researchers present their findings, they do not always explain how they arrived at a particular interpretation, which leaves the reader questioning the reliability of the findings (Baxter and Eyles, 1997). Thus, in this section, I attempt to be as transparent as possible in the interpretation of my data. This chapter also outlines the initial observations I made about my research participants and the data I collected. I include these observations to contextualize my own personal positioning as a researcher, and how my observations influenced and shaped the course of the analysis. Finally, I present my findings in two parts. The first part answers the research question: What are the perceptions and ambitions of rural youth towards higher education? In answering this question, I first demonstrate how students see postsecondary education as a necessity in today's society. I then expand on these opinions by investigating how family background, socio-economic status and family members play important roles in influencing young peoples' values and goals towards attaining a postsecondary education.

The second part of my analysis focuses on answering a second research question: What is the role of space, place and identity in forming these attitudes? In this section I investigate students' sense of community, and how it affects rural youth's educational, occupational and mobility trajectories. I then explore the importance of place on rural youths' educational decision-making, and how various social networks, through the transference of social capital, 
reduce the effect of distance and proximity on rural youth's postsecondary choices of where to go to school.

\section{Making Sense of Qualitative Data}

Initially, a random selection of twenty students' interviews were transcribed in their entirety, over the six months following the data collection. While transcribing these interviews, I began to identify themes that had been raised within the interviews. With these themes in mind, the remaining ten student interviews and eleven teacher interviews were partially transcribed. Sections of the interviews that I deemed to be irrelevant to the study were omitted from these transcripts. However, notes on the content of the omitted sections were made in the transcripts for revisiting, should the information prove relevant after further analysis.

The qualitative data analysis software program Atlas. $t i$ was used to help analyze the interview transcripts. I read over the transcripts to further identify themes that were being raised among the interviews and to isolate and "code" phrases, taking note of whether they corresponded to aspects of the themes that had been identified and were being identified during the initial reading. During this initial sorting, many codes changed and evolved. A second reading of the interview transcripts allowed for further identification of additional phrases that corresponded to new themes and/or codes that had been overlooked during the initial examination.

Once I was confident I had a fairly thorough list of codes, I began to organize and filter them. This was accomplished by merging several codes into one, or occasionally renaming existing codes. The merging or renaming of codes was only done after reviewing the phrases linked to each code, and deeming the merge appropriate. In some cases, codes were developed and assigned to fragments of the interview text without establishing a corresponding theme. 
Once codes were established, they were used to review the established themes (see Table 4.1).

Themes were altered to more accurately reflect the general trends being presented by the data.

\section{Table 4.1: List of Established Codes Vis-à-vis Place and Educational Aspirations}

\begin{tabular}{|c|c|}
\hline Codes & Sub codes \\
\hline \multicolumn{2}{|l|}{ Definition of Community } \\
\hline \multicolumn{2}{|l|}{ Definition of Urban } \\
\hline \multicolumn{2}{|l|}{ Definition of Rural } \\
\hline \multicolumn{2}{|l|}{ Rural: } \\
\hline & isn't a factor \\
\hline & limits postsecondary \\
\hline & you have to leave to get a PSE \\
\hline \multicolumn{2}{|l|}{ Manitoulin: } \\
\hline & $\begin{array}{l}\text { Real World vs. No-Where Land } \\
\text { there's nothing for me here }\end{array}$ \\
\hline \multicolumn{2}{|l|}{ Characteristics of Students } \\
\hline \multicolumn{2}{|l|}{ Factors affecting PSP } \\
\hline \multicolumn{2}{|l|}{ Cost: } \\
\hline & Is it a factor? \\
\hline & How I will pay for school \\
\hline \multicolumn{2}{|l|}{ Distance: } \\
\hline & Doesn't have to be a factor \\
\hline & It's good for them \\
\hline & Is a factor! \\
\hline \multicolumn{2}{|l|}{ Family: The importance of } \\
\hline & went, so I want to go \\
\hline & my parents didn't go, so I wanted to \\
\hline \multicolumn{2}{|l|}{ Friends: the importance of } \\
\hline & willing to travel further friends \\
\hline & Share similar goals \\
\hline \multicolumn{2}{|l|}{ Perceptions of PSE } \\
\hline & you need PSE \\
\hline & Way of getting off the Island \\
\hline & We're expected to go \\
\hline & Why people don't value PSE \\
\hline \multicolumn{2}{|l|}{ Getting off the island and it's challenges } \\
\hline \multicolumn{2}{|l|}{ Ideologies about BOYS } \\
\hline \multicolumn{2}{|l|}{ Ideologies about GIRLS } \\
\hline \multicolumn{2}{|l|}{ Ideologies about who will go on } \\
\hline \multicolumn{2}{|l|}{ Ideologies about who will not go on } \\
\hline How PSE was promoted to Students & \\
\hline
\end{tabular}

Using the "Network View" option of Atlas.ti, I was able to generate visuals that allowed me to see the links between the various phrases, codes and themes with which I was working. I 
was able to visualize the linkages between codes, see which codes related to other codes most often, which codes linked to themes outside the themes I had originally assigned them, and how the themes themselves were linked together. By using the "Family Generator" option, I was able to sort data according to the varying identities of my research participants. Therefore, in the Network View platform, I was able to examine various axes of identity for the research participants, including: gender, age, grade level and ethnicity. Of these, gender surfaced as the most significant aspect. Apart from the obvious family comparison of teachers versus students, the sample (31) was too small to show any significant variations in perceptions and opinions towards postsecondary education, except in the case of differences between young men and women. Consequently, only a comparison of perceptions according to these axes is reported in the results. A flow chart was created to help visualize the relationship between the codes as illustrated in the Network View (see Appendix J).

\section{Making Sense of Quantitative Data}

This section outlines the process that I undertook to analyze the data collected from the questionnaire. These data were coded by assigning alphanumeric values to each question response and then it was entered it into an Excel spreadsheet. This allowed for easier analysis of data. The software program SPSS was then used to run frequencies and cross-tabulations in order to provide a general understanding of the background of the student population. These results were then used to provide a broader context for the qualitative data.

\section{Preliminary Remarks about the Data}

\section{Social Capital and Sense of Community}

Some of my most important observations about the data stem from my own experience on Manitoulin Island and from immersing myself into the community for six weeks. From the 
moment I crossed the bridge from the mainland onto the Island, I knew I was entering a different world. My first memory of being welcomed to the Island was when I met the woman who offered me, (practically a stranger), a place to live while I conducted my research at Manitoulin Secondary School, with no expectation of compensation. This was my first glimpse of the strong sense of community and the abundance of social capital available on Manitoulin Island. Ultimately it is what I believe is an important identifying component of who leaves, who stays, and why (Looker and Andres, 2001; Ainsworth, 2002; Brooks, 2003; Corbett, 2005; 2007a).

My next glimpse of this strong sense of community took place when I arrived at my hostess' home. I had asked a friend to drive me over to the Island from Sudbury, Ontario. After some confusion over of the directions I had been given, we finally arrived at my hostess' house to find it empty, the door unlocked with a note taped to it. The note informed me that my hostess had to go out, that she would be back shortly, and that I should make myself at home. I found this invitation strange. I have always been one for locking my doors, even in the rural community where I grew up. However, here on Manitoulin Island, my hostess did not think twice about leaving her home unlocked or inviting me in while she was away. I was amazed at the feelings of trust and safety my hostess felt in and for her community. I addition, my hostess welcomed my friend to spend the night instead of making the two and a half hour drive back to Sudbury that evening. Through this experience, I realized that I had entered a different sort of community filled with hospitality and trust.

I was on the receiving end of (and personally benefited from) the social capital of being a temporary Islander from that point on. I received assistance and guidance at Manitoulin Secondary School from support staff, administration, teachers and students. I experienced similar feelings during after-school hours when I was out walking or biking, buying groceries or 
frequenting local businesses. I received greetings and introductions to other community members throughout my interactions, and received sincere inquiries about my research progress from those who "knew" me. These were just a few forms of the support that I received while on the Island. The strong social networks between its community members were quite visible to me. Members of the Island community greeted one another, often stopping to talk to one another. If they recognized each other while driving in opposite directions down the highway, they would try and stop to say "hello", as I witnessed on more than one occasion.

I also began to develop my own sense of community while living on Manitoulin. By taking long walks, biking along its lakes, building friendships and nurturing social networks in the local communities, I also began developing a comfort and a pride for the land and community. For the first time in a long while, the fast pace of my busy life as a graduate student slowed, and I had the chance to indulge in recreation and relaxation outside my hours at Manitoulin Secondary School. I would chat with people in the bakery, local restaurant, pub and grocery store and made many connections. These experiences and interactions helped me develop my own sense of community. In addition, they were a window to understanding the lives of the youth and the people living on Manitoulin Island.

\section{Division of Postsecondary Education}

During interviews, questions were phrased in terms of "postsecondary education" defined in my glossary as any process of formal education which is experienced at a college, university, or vocational institution. Generally, I did not verbally distinguish between pursuing a postsecondary education or going to college, university, or any other alternative training program. I also avoided implying a sense of superiority for one educational path over the others. However, often students distinguished between postsecondary education in general and their 
individual educational paths without prompting or probing. For example, during some interviews I asked students to elaborate on their response to why they thought postsecondary education was important. Many of the interviewees justified their responses by identifying the educational path they themselves were taking. Interviewees revealed a set hierarchy within the different postsecondary educational choices. Some students identified going away to a college or university as a more favourable option as opposed to remaining in the community and/or learning a trade or local skills. I found this observation interesting because I also held very similar views of postsecondary education when I was a high school student and in my beginning years of university. It was only when I started to become interested in the topic of educational attainment that I began to question this sense of superiority. Michael Corbett's Learning to Leave is a great example of a group of young people who were seen to have taken a less than satisfactory life path by staying in the community to fish, rather than leaving the community to attend a postsecondary institution. However, Corbett reveals that this group of young men seemed satisfied with the choices that they made, leading me to question the notion of superiority in light of one's individual habitus.

\section{Youth's Perceptions of Postsecondary Education}

\section{Postsecondary Education Is Important}

"Most of the good paying jobs now, you need a postsecondary education ... like, every employer, even if you don't need it, they still want you to have it. And... without it, you don't feel like you measure up to anybody else anymore. If you just go into the workforce, people look down on you. Like "how come they were so lazy that they couldn't just go and do one year in postsecondary to pick up the degree they need or a diploma?" (Harper - Grade 12 student)

One of the major findings of this study is that all of the youth interviewed from Manitoulin Secondary School agree that postsecondary education is important. There was a general understanding that "postsecondary is something you should do, so that you'll succeed" 
(Carrie - Grade 12 student). To them, success is measured in terms of the type of job you acquire, how much money you make, if you are able to provide for your family, if you have job security, and if you are happy with what you do for a living.

Students also felt that you had to have a postsecondary education. Although they recognised that there were successful people in their families and broader community who did not have a postsecondary education, they believed that success without a postsecondary education was not truly possible without leaving the community and attaining some level of postsecondary.

It is no surprise that the students who participated in this study see postsecondary education as a necessity. Other studies, including Corbett's (2007) Learning to Leave, indicate that a postsecondary education is perceived to be the optimal path for youth - especially for rural youth. Rural youth believed that a postsecondary education provides access to a larger array of job options and opens doors to lifestyles which are not readily available in rural communities. Parents, peers, teachers and community members are all important in (re)shaping rural youths' views towards their educational goals, and influencing their opinions about whether they stay or leave their communities.

When asked to explain why a postsecondary education was important, students would often justify their opinions by comparing themselves to other members of their families or communities to illustrate what they did and did not want for their own futures. For example, one young women I spoke with stated:

"My sister didn't go anywhere and she's bored at work. She makes like, 8 bucks an hour...the company she is working for is on the rocks financially... And she's got no job security. If the company closes, she's out of a job and then she has to find another minimum wage job in the area. So, getting an education is important to me, so I can get away from the Island... Like, I love to travel. And my sister can't afford to travel 
anywhere. So just being able to do what I want, when I want, having that independence, is my reason for wanting a postsecondary education" (Oriana-Grade 12 student).

Many students made reference to family and community members who they did not want to imitate and often justified their desire to get a postsecondary education as a way of ensuring that they did not end up in a similar situation. This is the same inculcating process that shapes one's habitus and sense of place. These young people see members of their families and communities in a variety of socio-economic positions, and make choices for themselves about their own future based on what they feel is attainable and demonstrated to them. The fact that all participants reported that they were going to pursue a postsecondary education, (at least eventually), can be interpreted as youth seeing postsecondary studies not only as a necessary option, but also as one that is a tangible option for them.

Affordability appears to be a significant factor in other studies (Finnie et al., 2004; 2005; Finnie, 2002; Corak, et al., 2003; Christofides, et al., 2001; Butlin, 1999), but when asked if the cost of postsecondary education influenced their choice, 76.7 percent of the students in this study reported that they were not concerned with the cost of postsecondary education (see Table 4.2). The youth in this study felt that attaining a postsecondary education was worth the price of having to leave home. Even the potential of accumulating a large student debt did not deter them, indicating that perhaps affordability may not be as significant an aspect as the empirical studies would have us believe. However, the majority of students, when asked how they were going to pay for their postsecondary education reported that they had trust funds established by parents or grandparents, and therefore were not worried about how they were going to afford the costs of tuition, books and other postsecondary education costs. Some of the students in this study also reported that they would receive Band funding, that they had personal savings and/or that they would establish student loans as a means of paying for their schooling. 
Table 4.2: Does Cost Influence Youth Postsecondary Education Choices?

\begin{tabular}{lrrr}
\hline $\begin{array}{l}\text { Do the following factors influence } \\
\text { your choices for next year? }\end{array}$ & Yes & No & Unknown/* Unreported \\
\hline Cost & & & $1^{*}$ \\
\hline Male & 1 & 6 & 0 \\
Female & 5 & 17 & $0.07^{*}$ \\
\hline Total (\%) & 20.0 & 76.7 & \\
\hline
\end{tabular}

All of the students I interviewed intend to obtain a postsecondary education, but it is unlikely that this opinion is shared by all of the youth on Manitoulin Island or at Manitoulin Secondary School. Given the statistics presented earlier, it is likely that a large percent of the students attending Manitoulin Secondary School will not pursue a postsecondary education. When teachers were asked to describe students today, many of the teachers shared an impression that students lack motivation and the ability to set goals for themselves. In contrast, almost all of the teachers who participated in this study agreed that the students who likely participated in my study were "the crème de la crème" (Mr. P), meaning that the students who volunteered for my study were academically successful, and more outgoing. The teachers characterised this group of students as being well organized over-achievers, who sought opportunities to gain new experiences, joining many groups, clubs or extra-curricular activities. These young people were believed to be motivated and goal oriented, coming from motivated families who were goaloriented as well. Therefore, this study is missing representatives from the group of youth who do not see themselves as postsecondary candidates. As a result, this study can only provide an understanding of the role of habitus in forming the values and beliefs of rural youth who value postsecondary education. 


\section{The Role of Habitus}

\section{Family}

"Um, well a lot of people in my family didn't go to postsecondary. My dad is one of like, 8 children who actually went. So, I don't want to have the jobs that they have. I actually want to do something that I like". (Raeanne - Grade 11 student)

For most students in my study, families play(ed) an important role in their educational decision-making. Consistent with other studies, almost all of the students who were planning to pursue a postsecondary education claimed that at least one of their parents had a postsecondary education (see Table 4.3). Nine of the 16 students who stated that they wanted to pursue university reported that their father had a university education. Eight of those 16 students reported that their mother had a university education. In addition, 6 of the 9 students who reported that they intended on going to college, reported that their father had either some postsecondary or a college education. Six of those 9 students reported that their mother had attained some level of postsecondary, albeit college or university. In contrast, none of the students with parents who had postsecondary education reported a desire to go directly into the workforce.

Many of the students I spoke with reported that their parents expected and encouraged them to pursue postsecondary studies. As illustrated in Table 4.4, students reported that for the most part, their parents had similar, yet slightly higher educational expectations than they themselves had. For example, 17 students reported that their parents wanted them to go to university, whereas only 16 students reported that they wanted to go to university. In contrast, 9 students stated that the intended to go to college eventually, while only 7 students reported that their parents expected them to go to college. Nevertheless, students reported that both their goals and their parents' goals were similar and included pursuing a postsecondary education. 
Table 4.3: Students' Future Paths and their Parents' Level of Education

\begin{tabular}{|c|c|c|c|c|c|c|c|}
\hline $\begin{array}{l}\text { When I finish high } \\
\text { school I want to ... }\end{array}$ & $\begin{array}{l}\text { Get a job and } \\
\text { start working }\end{array}$ & $\begin{array}{r}\text { Go to } \\
\text { college }\end{array}$ & $\begin{array}{r}\text { Go to } \\
\text { university }\end{array}$ & Other & $\begin{array}{r}\text { Go to } \\
\text { college } \\
\text { and } \\
\text { university }\end{array}$ & $\begin{array}{r}\text { Go to } \\
\text { work } \\
\text { place and } \\
\text { university }\end{array}$ & Total \\
\hline Total & 1 & 9 & 16 & 1 & 2 & 0 & 29 \\
\hline $\begin{array}{l}\text { Father's level of } \\
\text { Education }\end{array}$ & & & & & & & 24 \\
\hline Less than grade 9 & 0 & 0 & 1 & 0 & 0 & 0 & \\
\hline Grade 9 to 13 & 1 & 3 & 4 & 1 & 0 & 0 & \\
\hline Some postsecondary & 0 & 3 & $\mathbf{0}$ & 0 & 0 & 0 & \\
\hline A college degree & 0 & 1 & 1 & 0 & 0 & 0 & \\
\hline A university degree & 0 & 0 & 9 & 0 & 0 & 0 & \\
\hline $\begin{array}{l}\text { Mother's level of } \\
\text { Education }\end{array}$ & & & & & & & 26 \\
\hline Less than grade 9 & 0 & 1 & 0 & 0 & 0 & 0 & \\
\hline Grade 9 to 13 & 1 & 2 & 3 & 0 & 0 & 0 & \\
\hline Some postsecondary & 0 & 2 & 2 & 0 & 0 & 0 & \\
\hline A college degree & 0 & 3 & 2 & 1 & 0 & 0 & \\
\hline A university degree & 0 & 1 & 8 & 0 & 0 & 0 & \\
\hline
\end{tabular}

Table 4.4: Postsecondary Goals and Ambitions after High School

\begin{tabular}{|c|c|c|c|c|c|c|c|}
\hline $\begin{array}{l}\text { When I } \\
\text { finish high } \\
\text { school... }\end{array}$ & $\begin{array}{c}\text { Get a job } \\
\text { and start } \\
\text { working }\end{array}$ & $\begin{array}{r}\text { Go to } \\
\text { college }\end{array}$ & $\begin{array}{r}\text { Go to } \\
\text { university }\end{array}$ & Other & $\begin{array}{r}\text { Go to } \\
\text { college and } \\
\text { university }\end{array}$ & $\begin{array}{l}\text { Go to work } \\
\text { place and } \\
\text { university }\end{array}$ & $\begin{array}{l}\text { Unknown/ } \\
\text { unreported }\end{array}$ \\
\hline \multicolumn{8}{|l|}{ I want to... } \\
\hline Male & 1 & 1 & 5 & 0 & 0 & 0 & 1 \\
\hline Female & 0 & 8 & 11 & 1 & 2 & 0 & 0 \\
\hline Total & 1 & 9 & 16 & 1 & 2 & 0 & 1 \\
\hline \multicolumn{8}{|c|}{ My parents want me to... } \\
\hline Male & 0 & 1 & 4 & 0 & 2 & 0 & 1 \\
\hline Female & 0 & 6 & 13 & 2 & 0 & 0 & 1 \\
\hline Total & 0 & 7 & 17 & 2 & 2 & 0 & 2 \\
\hline \multicolumn{8}{|c|}{ Most of my friends will... } \\
\hline Male & 0 & 4 & 2 & 0 & 2 & 0 & 0 \\
\hline Female & 3 & 8 & 5 & 1 & 4 & 1 & $\mathbf{0}$ \\
\hline Total & 3 & 12 & 7 & 1 & 6 & 1 & 0 \\
\hline \multicolumn{8}{|c|}{ My teachers have encouraged me to... } \\
\hline Male & 0 & 2 & 5 & 0 & 1 & 0 & 0 \\
\hline Female & 1 & 4 & 14 & 1 & 2 & 2 & 0 \\
\hline Total & 1 & 6 & 19 & 1 & 3 & 0 & 0 \\
\hline
\end{tabular}


Parental values about postsecondary education hugely influenced the educational and career goals of young people. Young people's predisposition towards school and pursuing a postsecondary education may be shaped by their parents' perceptions that success hinges on their children going on to postsecondary. As one such young man stated when asked about who influenced him most and why: “We already knew that I wasn't going to be a high school dropout" (Billy, Grade 12 Student). For this young man, making the choice to go on to postsecondary was preordained. The choice does not lie in whether or not to go to postsecondary, but what program to select and what career path to follow; for some, even that is second nature.

\section{Friends}

"Like, everyone that I know, like, my little group, we're all going to university. And I guess, I guess another influence of making me go to university is just my friends. I mean, they're all doing it". (Diana-Grade 12 student)

In addition to family, friends are also important in shaping the perceptions and values of young people. Peer groups share and reinforce students' feelings about their place within their social worlds. Students reported that most of their friends had similar educational goals. As one young man pointed out:

"Everybody I know, like at least three quarters of them are going on to postsecondary. We 're all the same. We want to get off this island and do something with our life. We've lived this way so long, we don't want to live this way no more (Maxwell-Grade 12 student).

When asked to indicate which educational path their friends would likely take, students reported that they thought that most of their friends would go on to postsecondary (refer to Table 4.4). Most students (27) stated that they would be pursuing either college or university, and similarly (26) reported that their friends would also be pursuing a postsecondary education. Sixteen students reported that they wanted to attend university, but only 7 reported that their friends would likely be going to university. In contrast, only 9 students reported that they wanted to go 
to college, but 12 students reported that they thought their friends would likely be going on to college. This shows that although most of the students had aspirations to pursue higher education, they did not necessarily think that their friends would achieve the same level of educational attainment as themselves. It should also be noted that the students themselves created an additional category while answering the survey, combining college and university. Six students reported that the majority of their friends would be going on to either of these postsecondary education options, thus accounting for some, but not all, of the discrepancy.

It can be stated that youth in this study tended to surround themselves with people who have similar goals. Although the importance of peer groups in educational decision-making has not been a focus in the literature, when considering the importance of habitus and students' sense of place, it is not surprising that students would form peer groups with friends who uphold similar educational goals. By surrounding one's self with peers who share the same values and educational aspirations, these youth are reinforcing the values they acquired from their parents, grandparents and siblings. Since they already gravitate towards those choices that are most "sensible", "coherent" and "convenient", surrounding oneself with like-minded people would only strengthen one's sense of belonging and sense of place.

There are youth who have not had these same values reinforced at home and in these cases, peers can actually help create an environment and sense of place and belonging for their friends. A few students reported that neither themselves, nor one of their friends was on the path to postsecondary education before they started "hanging around" with their current peer group. I was talking with one young man and asked him to elaborate on what might hinder one's choices of pursuing a postsecondary education:

"Like if I didn't have the same girlfriend since grade nine, I wouldn't be going probably. I might be. But I definitely wouldn't be going to university... or anything. Going away is a lot of 
money... [Having a relationship] changes a lot of things... Even like where I am going is kind of set on that too" (Aden, Grade 12 student).

Another young woman reported that she and her father played an important role in (re)shaping her boyfriend's goals towards postsecondary studies:

"...when I started dating him, he didn't care about school. And he was getting marks that just got him through the courses. And then he started coming over to my house all the time. And my dad started to get to know him, and he would bring up 'so what do you want to do with your life?' And he [my boyfriend] would be like 'I'm just barely passing!' And my dad just started bugging him and bugging him and I think he got him [my boyfriend] into it, and now he is going to go to college and he has some direction, so..." (Phoebe, Grade 12 student).

These examples illustrate the importance of having peer groups and social networks in general.

The stories from Aden and Phoebe also show how peers can influence each other. These social networks helped students form a sense of place within the school and develop values towards higher education. These social networks were valuable in reinforcing the idea that postsecondary education is attainable, albeit with effort.

\section{Teachers}

'Sometimes I'll ask them, ... 'who wants to live on Manitoulin for the rest of your life?' And, of course Nines, Tens and Elevens, a lot of them: 'Oh, no. I'm going to the cities'. And I'm like, 'well, think about it. If you don't go to college or university.... if you get a minimum wage job, you might do better, but if you get a minimum wage job, I mean, what's that get you in a city? $A$ shared apartment and a bus pass eh?' And I go 'if you go and do an apprenticeship, I mean you are getting paid right away more that you were making. And you are doing this, and you are learning a trade. You can buy a house and get a vehicle. Your life is a lot more easier and a lot more fun. A lot more nicer'. So, I'm always pushing it. Yep, definitely." (Mr. M)

Just as family and friends played a critical role in shaping and influencing students' views of postsecondary education and their future educational paths, teachers also played an essential role. This fact was identified by both students and teachers. As Mr. M stated above, he often provoked and encouraged students to pursue a postsecondary education. Teachers themselves 
claimed that they promoted postsecondary education to their students on a daily/weekly basis. Not only did teachers act as models of "success" with regards to the importance of attaining a postsecondary education, they also provided a definition of what it meant to pursue some form of postsecondary education.

Many of the teachers I spoke with stated that they believed that a postsecondary education was important, at any level. They also felt that its importance was only going to increase over the next twenty years. Several of the teachers I conversed with stated that they attempted to promote postsecondary education to their students, but the type of postsecondary education promoted often mirrored the academic stream in which they taught. Moreover, most of the teachers said they promoted postsecondary education by explaining the income differential between having a postsecondary education and not, especially with regard to the trades. In fact, approximately half of the teachers I interviewed, expressed the importance of trades, and declared that they promoted trades to their students. In general, teachers reinforced student notions of the link between postsecondary education and "success" by referring to the benefits of having a postsecondary education, including income, lifestyle (including where you live), and increased job choice.

The students I interviewed supported the teachers' opinions that they play(ed) an important role in their educational decision-making. Students conveyed that teachers were role models, who embodied the importance of postsecondary education through their lifestyles, and daily interactions with students and the community as a whole. Teachers were reported to be key figures in both the promotion and encouragement of students' educational paths. Teachers not only helped students to identify their strengths, but helped them utilise those strengths in selecting a specific educational path. As illustrated in Table 4.4, students felt that their teachers' 
encouragement reflected their own ambitions. One curious result from the questionnaire revealed that 19 students felt that their teachers had encouraged them to go on to university, whereas only 17 students believed that their parents wanted them to pursue a postsecondary education. It is difficult to explain this discrepancy; however, it might indicate that teachers generally have higher expectations for their students than parents do. This table also shows that one student felt that their teachers had lower expectations for them. Talking with this student directly, I discovered that this young woman had had an encounter with one of her teachers and had been discouraged from pursuing postsecondary studies. This teacher (perhaps unknowingly) squashed the student's educational ambitions and encouraged her to join the workforce instead. This example demonstrates that teachers can have a negative or positive influence on students.

As both educators and role models for young people, teachers play an important part in transferring social and cultural capital to youth. Both teachers and students claimed that teachers not only suggested career paths where students might find success, but also encouraged them to go after their dreams and provided advice on how to achieve their goals. For example, one young woman declared "... My teachers, like I tell them that I want to be a teacher and they say, 'Yeah, you'll be good at that.' So, kind of getting it reaffirmed makes me feel better about it" (WillowGrade 12 student). Since teachers are such important figures in the lives of students, the advice they give, including course choices at the high school level and program choices at the postsecondary level, is pivotal to many students' plans for postsecondary education. This transference of capital is invaluable in helping students make choices about their futures.

\section{Community and Community Members}

"...[T]he more people you have educated, it's just [an] influence on others." (Cleo - Grade 12 student) 
"Um. I think that the community does push towards postsecondary. That you're just expected to go" (Dana - Grade 12 student)

“... [W] hen people are applying and stuff. You have people all over the Island saying 'Oh great! Oh great! You're going off somewhere. What are you going to do?' And they are always so interested for you. And, then you have someone who says 'I'm just going to work at Foodland and figure out my life' and they're like 'Oh... Okay. You can do that, I guess' [Sounding disappointed]. They just seem to have more respect for you if you are doing something further with your life" (Phoebe -Grade 12 student)

The above quotations demonstrate a variety of beliefs about the influence of community on postsecondary education ideologies. In general, the youth of Manitoulin Secondary School expressed the notion that their community(ies) shared their values about postsecondary education. Students reported that they believed members of their individual communities, as well as others on Manitoulin Island, thought that a postsecondary education was important. Some students also believed that members of their communities played an important role in encouraging them to pursue postsecondary studies. Most students stated that community members encouraged them to leave the Island and get a postsecondary education, and assured them that attaining a postsecondary education was expected of them. Many students felt that they would be disappointing their community or be viewed as unsuccessful or lazy if they did not pursue further schooling.

Both students and teachers expressed the opinion that people with a postsecondary education in one's community were role models for youth. Interviewees stated that having siblings, family members, or neighbours who were pursuing or had completed a postsecondary education, meant that exciting and insightful stories of the "real world", were shared, making the idea less foreign and more attainable. Many students explained that they were not nervous to leave the Island to begin their postsecondary studies because they knew people who had pursued 
a postsecondary education and had returned to share what it was like and what their experiences had been. One teacher commented:

"We have students who have gone off to university who like to come back and hang out. So [the students] get the direct link with their older peers with how their life has been [off the Island]. Because there is a real small community here... and you have the older siblings coming back [during] the summers, and so word gets around.... as long as they have knowledge of what is there, they are empowered!" (Ms. S)

In Ainsworth's (2002) study, community members are seen as important in the sharing and building of social, cultural and community capital. In this study, these forms of capital are used to transmit information about postsecondary studies, life outside the community, and what is possible to achieve within as well as beyond the community with a postsecondary education. Having these resources and persons available and accessible to youth while they are making important decisions about their educational and career futures helps them to assess the options, and choices.

A few of the students also referred to their teachers as members of their community, stating that these teachers continued to have an influence on their educational destinations even when they were no longer students in high school. Three of the students reported that casual unplanned meetings with past teachers, from either the elementary or secondary levels, also played a role in promoting the importance of postsecondary education. Teachers provided encouraging conversations about students' educational goals and inquired about a youth's plans after high school. These students indicated that their former teachers conveyed a general interest in their futures, and also implied an expectation that they would be leaving the Island to attain a postsecondary education. One young man commented on the role of his community in promoting postsecondary education, "Um, definitely. Yeah, especially when you see a lot of your teachers out of school. They always want to know what you're going to do after school. Where you want 
to go, what you want to be and stuff" (Sheldon - Grade 12 student). Again, the importance of community members on the formation of students' sense of place in the community is clear.

\section{The Influence of Locality and Capital Perceptions of Postsecondary Education}

In the first section of this analysis, I highlighted and discussed rural youths' perceptions of higher education, and highlighted the importance of family, friends, teachers, and community members as sources of social capital. In this next section, I combine the influence of these various sources of social capital and the effects of locality on rural youths' perceptions and ambitions. In doing so, I demonstrate the importance that growing up on Manitoulin Island had on the formation of these youths' identities, their perceptions of postsecondary education, its attainability, and their future goals.

\section{Sense of Community}

"I would describe my community as ... safe um.... very together. Everybody knows everybody. Like, um, you don't have to lock your doors. You don't have to lock your car doors to feel safe." (Olivia-Grade 12 Student)

"It's a nice place to raise a family. A lot less danger, kind of. Like there's.... there's still trouble, but, it's not Toronto kind of trouble". (Willow - Grade 12 student)

When I asked student participants to define the word "community", a common answer I received was "... a group of people that share common interests, or have common values" (Cleo Grade 9 student). Variations included a "close-knit group of people with the same histories", "collective goals", and "common interests"; "people who worked together to meet the needs of other members"; and the "general feeling of familiarity among its inhabitants". Most students reported feeling that the Island was more family-oriented than larger urban areas. A few of the female students also declared that they would like to move back eventually since they believed that Manitoulin Island was a "nice place to raise a family". 
Similar to other studies which have focused on sense of community in rural areas, almost all of the students conveyed a sense of the Island's superiority over urban places, citing a strong sense of community, family, friendliness and overall safety (Hektner, 1995). When asked to describe their community and Manitoulin Island on a larger scale, students spoke fondly of where they lived, and often compared the Island to larger places like Toronto. They expressed a sense of comfort on the Island due to its spaciousness, wildlife, fresh water, clear skies, as well as a perceived slow-paced environment. They also reported a greater sense of safety. In comparison, urban areas such as Toronto were described as busy and noisy, and youth often commented on increased pollution and smog. In addition, the youth often saw urban places as having significantly more violence, crime, abuse and increased social problems such as homelessness.

When asked what feelings they had towards going away to attend school, some students reported being scared because of the negative beliefs they held about urban areas. All of the students reported a sense of excitement to be heading off the Island to attend school, but quite a few had feelings of unease and nervousness, especially about getting lost, because, as Diana stated "cities are so much bigger than the Island". Not knowing how to navigate in the city, leaving family and friends behind, not knowing anyone, and having to live on their own were also factors that contributed to their unease. Some of the students noted that it would be easier to pursue a postsecondary education if they had grown up in a city, since they would be able to stay at home and save money, and they would already be comfortable city life. Youth who had lived in or frequented larger urban centres, reported being less nervous about going off to postsecondary destinations since they already had knowledge of the transit networks and geography of these locations. 
In the studies of Hektner (1995), Jones (1999), and Gledinning et al. (2003) explanations of youth mobility, the strong positive sense of community that rural youth report above would lead us to believe that perhaps these students may not be eager to leave their communities to pursue a postsecondary education. Especially, given the uneasiness and nervousness these youth expressed in terms of having to venture into the unknown without being familiar with the place, and without their important social networks to ease the transition. Even though these youth have a relatively idyllic image of their rural community, they also feel that the Island is limited in the opportunities it can offer, and that they must travel elsewhere in order to gain the experience to be successful in today's world.

\section{Why Some Rural Youth Choose to Leave}

"[I]f you want to leave you can go on to postsecondary... If you want to go to postsecondary you have to leave". (Oriana-Grade 12 student)

There were apparent differences in the ways in which the young people perceived Manitoulin Island versus how they envisioned more urban areas. Some of the young people I spoke with felt that there was nothing for them on the Island:

"You can't really get anywhere in your life if you live here... There's not like really rich people and really poor people. Really, everyone is in the same boat. There's not really any way to get ahead here. I don't know. I just kind of feel like you're stuck when you live here" (Aden - Grade 12 student).

Students felt that they were limited in their career choices on the Island, and although many expressed a desire to return to the Island eventually, most believed that they would be more successful in attaining a job elsewhere. The teachers I spoke with expressed this sentiment: "There isn't as much focus on what the youth can do here, as there is on what the youth can do elsewhere. And that's part of the problem. If they can't picture themselves being here, it's definitely going to be difficult" (Ms. S). 
One's sense of community and sense of belonging to that community seemed to be overshadowed by perceptions of what is available elsewhere. This perception seems to greatly influence a youth's choices to leave or stay in a community, and where to go, if they decide to leave.

Most of the students I spoke to were looking forward to leaving Manitoulin Island and living in the city while they completed their postsecondary studies. As can be seen in Table 4.5, 96.7 percent of the students reported that they intended to leave Manitoulin Island eventually, with only 66.7 percent reporting that they would like to return to the Island at some point. When interviewing and discussing the questionnaire responses with students, specifically those pertaining to the topic of leaving home, those who stated that they intended to return to Manitoulin Island gave various responses. Some indicated that they would find work after school, they would return to raise a family, or only return to retire.

Table 4.5: Youth Mobility Plans

\begin{tabular}{lrr}
\hline & Count & Percent \\
\hline Do you plan on leaving Manitoulin Island eventually? & 29 & 96.7 \\
Yes & 1 & 3.3 \\
No & 20 & 66.7 \\
\hline I plan on returning to Manitoulin Island someday* & 7 & 23.3 \\
Yes & 7 \\
No & & \\
\hline * Some students reported YES, but plan only on returning when they retire & & \\
\hline
\end{tabular}

* Some students reported YES, but plan only on returning when they retire.

For youth who planned to leave, cities offered many more opportunities, including better career choices, youth-oriented activities such as shopping and movie-going, and more exposure to different ethnicities and cultures. Living on the Island left them with a feeling of isolation from each other, and from the rest of the world. One young woman referred to the Island as a "nowhere place" (Cleo - Grade 9 student), emphasizing the notion that few knew where 
Manitoulin Island was or that it even existed. This feeling was shared by others who felt that people on the Island were more sheltered and unaware of changes in the "real world". Many of the young people I spoke with identified "going away to postsecondary" as a way of "getting off the Island", and "experiencing the world that they felt they have been missing". For these youth, pursuing a postsecondary education allowed them to take that next step in their educational and occupational careers, and also take the next step in their lives, becoming independent and worldlier people.

Revisiting Gledinning's et al. (2003) explanation of the effects of youth mobility on sense of community and sense of attachment and belonging, despite the fairly positive sense of community young people painted, the lack of opportunities and activities for them on the Island, left them feeling socially excluded, and wishing to be elsewhere:

"Umm, dull. We don't have a lot of stuff here to entertain the teenagers. Umm, and it's improving I would say...We actually got new soccer nets this year" (Brogan, Grade 12 Student).

"'Cause like, around here, it's not like, you can go to the movies whenever you want, or the mall. It's like, 2 hours to get to the mall... But in a city it's like a 10 maybe 15 minute bus ride and you're at a mall or the Cineplex" (Gwyn-Grade 10 student).

" 'Cause even though I love this Island, and I want to come back to this island, there should be more for people my age. Like, if, cause not everyone is athletic. Not everyone is made to wear cadet boots. Like, on this island there [are] only a couple things to do. If you are athletic you go into hockey. If you are a good dancer there is ballet... If you like the military or want to get into the military there is Sea cadets. That's what's available here besides what is available here in our school. And there are some youth groups, [but] that all depends on what community you are in". (Deirdre - Grade 11 student)

These comments reflect the attitude of many of youth towards their communities. With a lack of available activities and opportunities for them, urban areas appear more appealing. Consequently, for this group of young people, the want and need to experience more than what the Island has to offer is a driving force behind their desire to leave the community and pursue a postsecondary education. 


\section{The Effects of Geography on Youth Mobility}

“...like I said before, it doesn't matter where you are. If you want to go [on] to postsecondary education, it's there. You just have to get there." (Oriana-Grade 12 student)

Many of the students who were born and lived on Manitoulin Island were fairly adamant that being from the Island or a rural environment had no effect on whether a person pursued postsecondary studies or not. However, when asked what influenced their choice of a particular school, for further education, many students indicated that distance from the Island, and cost of living away from home were both significant factors. Consistent with other studies, many of the students I spoke with identified factors such as fear of leaving home, distance and cost when asked to identify factors that might influence others youths' choices pursue a postsecondary education (Looker et al., 2001; Frenette, 2002; 2003).

Similar to the study conducted by Looker et al., (2001), the lack of exposure to a wider array of educational and occupational options as a result of being in a rural community, was identified as a significant factor influencing the educational paths for rural youth in my study. Many of the teachers I spoke with pointed out that the rurality of Manitoulin Island had a significant impact on students regarding their goals of earning a postsecondary education. Four of the teachers I spoke with also identified the unique position of their students, coming from a rural island community. As one teacher stated, "I think that partly it has to do with being on Manitoulin Island.... it's like when you cross the bridge, everything else [is] just out there. And, what happen[s] out there [has] no effect on life here." (Ms. L). Revisiting Ainsworth's (2001) argument that communities are important in providing spaces of social capital transference, exposing young people to both educational and occupational possibilities, reinforces the idea that communities are spaces where important socialization processes can occur. Overall, the youth of Manitoulin Secondary School are seen to be greatly affected by the remoteness of the Island, 
which in turn affects their choices whether or not to leave the Island to pursue a postsecondary education. And if they do choose to leave, where might they go and what might they pursue?

Four of the students reported in the interviews that they had moved to the Island between the grades of seven and twelve. These "outsider" students stated that they felt that the youth of Manitoulin Island were isolated, sheltered and clueless about what it was like in the "real world". They felt that the youth of Manitoulin Secondary School were more sheltered because they had not experienced the "real world", and that they would be more likely to stay at home and "inherit the family farm" instead of venturing off the Island and earning a postsecondary education. These students, (and others who reported that they were frequent travelers), felt that many of their peers from Manitoulin Island who did not have much experience off the Island would experience a huge cultural and social shock upon going on to pursue a postsecondary education. These ideologies also support the argument that rural youth are, (or are perceived as being) less exposed to various educational and occupational choices, ethnic groups and cultural lifestyles, and that this lack of exposure may hinder their own ambitions and choices in the future.

\section{The Influence of Social Capital on Issues of Distance}

As illustrated in the first part of this chapter, social networks, including family and friends, play an important role in rural youths' perceptions and ambitions towards higher education. The second part of this analysis focused on how family influenced rural students' perceptions of postsecondary education, revealing that all participants have ambitions to attend a postsecondary institution. This final section will highlight how family influences where students decide to pursue postsecondary studies. 


\section{Family}

" [I don't want to go to school too far away because] I'm really close to my family and I guess just scared of leaving them." (Diana - Grade 12 student)

The students participating reported that their choice of city and school was greatly influenced by the presence of family. The influence of family on choice of school and location was attributed to a variety of different reasons, including a desire to be close to family and near the familiar, or wanting to be as far away from kin and home as possible.

Having family close by was an important factor for some when choosing which postsecondary institution to attend. Some students reported that they wanted to go to a specific school because they had family in the area with whom they could live for at least their first year. Living with family members also meant that they could save money and adapt to living in a larger city. One young woman I spoke with affirmed this:

"II chose a postsecondary institution in Sudbury] because I want to stay close to home and I have family in Sudbury that I could stay with, so that would also cut down on costs. Like, I could live with them and just make it a lot easier... easier to come home more often and stuff." (Ginger - Grade 12 student)

Other students claimed that they wanted to go to a city where they had family because they had been to that city before and felt comfortable being there. Not wanting to cut all family social networks, these youth attempt to use their social capital to assist them in becoming comfortable and familiar with living in a larger urban centre.

As illustrated above, some students stated that their decision to attend a specific school was because it was closer to home, and they might be able to return home more often. Quite a few students claimed that they were extremely close to their families, and that was why they did not want to be too far from home. However, there was also a group of students who expressed the desire to get as far away as possible from family and the Island. Their choice of school was 
influenced by how far away it was from the Island, so that they could get a sense of the "real world". One young woman shared her story:

"[I]f I went to Sudbury, my dad would come get me every weekend, and I want to experience it and I can't if my dad is coming to get me every weekend. And so I wanted to get far enough away so that I could experience it" (Phoebe - Grade 12 student).

In Phoebe's opinion, attending a postsecondary institution nearby would limit both her experience of life beyond the Island and her personal independence and growth.

Students were also influenced by the locations of schools which family members had attended. Eight of the students identified that their choice had been influenced by where either their parents or siblings had gone to school. By attending a postsecondary institution where a family member had attended, students could use the stories and experiences of their parents or siblings to help develop a sense of comfort with the school, and as a result, they could develop a general sense of what to expect, and consequently reduce the fear of the unknown.

Some students reported that they did not apply to their program of choice because it was only offered at distant schools. For example, a grade twelve student stated:

"Honestly I'd say [I'll] probably [go to] Sudbury. Laurentian. ...Why? 'cause I'm closer to home. And, I have friends there. I guess it's that whole new thing. If I go to Nippissing I've got to meet new people, new experiences, new town. But I don't know if I really want that my first year, you know? ...I got accepted to both. And the thing, the thing that is making me really unsure of where I want to go is that I got into my program of choice at Nippissing, but not at Laurentian".

Sudbury is relatively close to Manitoulin Island, and it is the nearest major service centre offering recreation, shopping and entertainment so students feel fairly comfortable with the idea of attending school there. In addition, since being close to family and friends was an important factor, this relative proximity likely accounted for the high proportion of students intending on pursuing a postsecondary education. For these students, a postsecondary education does not have to mean packing up and moving to an unfamiliar and far-off city. Instead, these youth were able 
to choose a school where returning home on weekends meant a scenic two and a half hour car ride.

\section{Friends}

"If their friends are going, they are more likely to go. If their friends are getting pregnant, they are more likely to stay home and get pregnant. If their friends are going to travel the world and do something else, then they will be more encouraged to go into the work world as well, and check things out themselves. Where friends go has a lot of impact on people" (Ms. S).

Like family, friends and peers also influence where someone goes to pursue a postsecondary education. When asked if the fear of leaving their friends in the community affected their choices to go on to a postsecondary institution, all of the students reported "NO". However, while discussing what factors influenced where students applied, both teachers and students' accounts highlighted the importance of having friends and peer groups attending the same school or living in the same city.

Friends and peers significantly influenced how far away students were willing to travel to attend school. Having friends going to the same school or being in the same city with peers was one factor that motivated students to follow their educational goals. One young woman said, "My best friend is going to [one school in Toronto] and I'm going to [another]. And I would say that it is a big part of why I'm not scared to go to Toronto next year... it's helpful when there is someone supporting you" (Olivia - Grade 12 student). Even those students who claimed to have a strong positive sense of belonging and comfort in cities like Toronto, often chose to attend a postsecondary institution where they knew at least one other person. More often than not, most students had arranged to attend a school within the same city with close friends. As a result, they were able to maintain at least one important social network in the process of cutting so many other ties by leaving their homes to attend school. 
As reported in the Role of Habitus section, under the subheading Friends, friends and peers, (particularly if they are older), are often important social networks supplying rural youth with a better understanding of what to expect once they move away. A few of the teachers at Manitoulin Secondary School pointed out that students from their classes tended to go in groups to the same handful of postsecondary institutions. One teacher observed that Manitoulin Secondary School students favoured the same group of schools for postsecondary pursuits: " $I$ find from Manitoulin Secondary, the students go to Western, um, Guelph, or Laurentian. Why do they choose those universities? Because every other kid chooses those universities" (Ms. L).

These observations reinforce the idea that friends are an important component of the community, providing a mobile form of social capital that can transcend place and help students choose schools and programs, especially those that are farther away from Manitoulin Island (Ainsworth, 2001). Hearing first hand what it is like to live in a city can be valuable motivational information to youth, who are eager to experience all that an urban area has to offer. Furthermore, deciding to leave the community, yet still maintaining some social networks, can be key to making a smoother transition from a rural community to an urban centre (James, 2001).

\section{The Effects of the Local Economy on Mobility Choices}

“...like you're kind of stuck in a rut. ... umm unless you come there with like a doctors degree, like, not many people are going to do that. I just, I don't know. If you came back here with like a business degree, like from here, going to the city you would have more job opportunities, better paid, more chances for getting farther ahead. Where here you would be stuck working the desk like every other person would be. Like, it's just, the opportunities are just not here that are available other places." (Phoebe - Grade 12 Student)

As the quotation above illustrates, rural youths' out-migration choices are greatly influenced by the jobs available in the local economy. In this study, the teachers and students stated that the career choices of the youth of Manitoulin Island were greatly influenced by the jobs available on the Island. Since Manitoulin Island has a limited economic sector, (based in 
agriculture, forestry, and tourism), both teachers and students felt that the various career paths were also limited, since the young people were not exposed to all the career opportunities available in a more diverse environment. Teachers reported that they observed students choosing paths reflected by careers demonstrated in the community. For example, three of the teachers identified teaching, Early Childhood Education and Police Foundations as being the favoured educational and career paths of local youth. As can be seen in Table 4.5, students reported a range of careers, with the greatest proportion hoping to become teachers ( 5 students). One student reported wanting to go into Police Foundations training. When asked why they had chosen these particular career paths, students often stated that they would like to return to the Island some day.

The results in Table 4.6 support the idea that locality is important in rural youth's educational decision-making. Even if students want to leave the Island to pursue a postsecondary education and live in an urban environment, more than half of the participants would like to return to the live on the Island someday. Consequently, students are choosing the professions that they believe with find them employment back in their communities one day.

"I love it on the Island. Like, after schooling I want to come back. I don't know if it's possible with a law career. It could be, so I want to come back if I can" (Ginger, Grade 12 Student).

These results support the idea proposed by Looker et al. (2001) that rural adolescents aspire to what they know and can imagine for themselves. Thus, since postsecondary education is promoted and supported by members of their family, friends and community, students seek educational and occupational fields they are familiar with, and those that they believe are best suited for them. Based on my interviews with students and teachers at Manitoulin Secondary School, these career choices often reflect the career choices of significant family, and community members. 
Table 4.6: Self-reported Career Choices of Rural Youth

\begin{tabular}{lll}
\hline What do You want to be when you grow-up? & Count $^{*}$ & Percent \\
\hline Teacher & 5 & 16.7 \\
Psychologist & 3 & 10.0 \\
Unknown & 3 & 10.0 \\
Artist (Visual) & 2 & 6.7 \\
Nurse & 2 & 6.7 \\
Mechanic & 2 & 6.7 \\
Doctor & 1 & 3.3 \\
Engineer & 1 & 3.3 \\
Lawyer & 1 & 3.3 \\
Hairdresser & 1 & 3.3 \\
Account Manager & 1 & 3.3 \\
Anaesthesiologist & 1 & 3.3 \\
Architect & 1 & 3.3 \\
Athletic Therapist & 1 & 3.3 \\
Business Owner & 1 & 3.3 \\
Physical Trainer & 1 & 3.3 \\
Developmental Service Worker & 1 & 3.3 \\
Pharmacist & 1 & 3.3 \\
Police Officer & 1 & 3.3 \\
\hline Total & 30 & 100 \\
\hline When tallying career chois & & \\
\hline
\end{tabular}

*When tallying career choices, only students' first choice was used.

\section{Ideologies about Males and Females and Postsecondary Education}

'I'd say that boys, if they don't want a postsecondary education there are more jobs available for them. Like the quarry, I'm sure there [are] probably some women working there, but it's not nearly as many. Like doing hard labour they can make more money then a woman can doing, like working at a store behind a counter making minimum wage". (Oriana - Grade 12 Student).

"I think a lot of it has to do with the gender dynamics that's changing in society. There's a lot more females going on to postsecondary education. And, um, these young males don't have to know those statistics to know that the girls in their classes are generally doing better than them" (Ms. S).

When initially asked to comment on the difference between males and females attaining a postsecondary education, most of the students stated that they believed that there was no difference. However, when asked to divide the students of Manitoulin Secondary School into 
groups according to those who would go on to pursue college, university, or the workplace, there was a general consensus that a greater number of young women would pursue a university education. It was reported that a fairly even proportion of young men and women would go on to college, and a significantly higher proportion of young men would go into the workforce directly from high school. When asked to explain why they believed these differences existed, many of the girls reported that it was easier for young men to get decent paying jobs on the Island coming directly out of high school, whereas young women were limited in the types of jobs they would be able to do. (This comment is further exemplified in Olivia's statement above). Some of the young women I spoke with shared the notion that most decent paying jobs on the Island would be in fields dominated by young men. As such, those females who did not pursue a postsecondary education were limited to "minimum-wage jobs" in the tourist and service sectors (these figures are supported by the statistics provided in the table on page 17).

An opinion held by all of my student participants was that males were less interested in school than females. Females were perceived as having a greater desire to go on to a postsecondary institution, specifically university. A few of the teachers I spoke with supported this opinion, stating that they observed more young men going into the work place and college, and more young women choosing to pursue university.

Michael Corbett's works $(2001 ; 2004 ; 2005)$ focus on the fishing community of Digby Neck in Nova Scotia and they also point out a similar reality with the young men and women who live there. Corbett highlights how there are very few, if any, good-paying jobs for young women in the community. Consequently, those women who wish to remain in the community must work at low-paying jobs or leave the community to get an education. The youth of Manitoulin Island face many of the same situations as the youth in the fishing village of Digby 
Neck. Taking into consideration current provincial and national educational trends, it is not surprising that the youth who participated in this study would perceive postsecondary education - particularly university - as the preferred option for young females in the community. With this similar understanding, both male and female youth on Manitoulin Island develop their sense of place and belonging in their community. In turn, they make important educational and occupational decisions based on similar feelings and understandings, resulting in the reproduction of gendered occupations in the community, and the out-migration of educated youth.

\section{Conclusion}

My results are consistent with the findings of other studies. Family background, and specifically the parents' level of education, is an important indicator of postsecondary participation. The majority of my participants had at least one parent with a postsecondary education. When asked what factors might affect the educational ambitions of students, students identified distance and cost as key determining factors. The participants also noted the importance of family, friends, teachers and community members in shaping and reinforcing their educational attainment goals. Through their support, encouraging interactions, and expectations, these individuals provide an important component of social capital.

In addition, there is a social and economic component to where students decided to enrol and in what program they choose to pursue for their postsecondary education. Family, friends and peer groups can reduce the impact of distance and cost of living away from home on students' postsecondary educational choices. The ability to live with family members can reduce the cost and apprehension of leaving home, as can attending a school with friends and peers. 
Also, through the sharing of positive experiences of attending school and living in urban settings, certain cities, friends and family members help alleviate further anxieties and apprehensions.

The youth of Manitoulin Island are very aware of the unique economic structures and limitations of the region, as well as the gender division of various job opportunities. Although many youth do not realise that they are making educational and career choices based on limited experience, the job aspirations of these youth are fairly generic, and reflect the reality of career choices possible on the Island. 


\section{Chapter Five: Concluding Remarks}

\section{Introduction}

In the opening chapter I highlighted two research questions that have guided this thesis: What are the perceptions and ambitions of rural high school students towards higher education? What are the roles of place, space and identity in the construction of these attitudes? During my investigation, and wading through this research process, much learning and understanding has taken place. I have gone beyond trying to find answers to the above questions. In my research journey, I have learned about the construction of youth identities in relationship to their socialspatiality, the investigative challenges of being a young researcher while working with youth, and older participants, and the challenges of collecting and analyzing data. Through reflexivity, I also have a clearer understanding of who I am as a researcher and student, and how I have changed since starting this research project two years ago.

The following chapter will discuss some of the key findings of this study, and will reflect my understanding of how localities influence rural youth, their values towards postsecondary, and their choices towards attaining a postsecondary education. In this discussion, I also highlight the importance of social networks, and suggest ways in which policy makers might attempt to focus on ways to foster and encourage the creation of new social networks. I also suggest ways in which existing social networks could make leaving a community to attend a postsecondary institution easier for rural youth. I will conclude this chapter by addressing the limitations and areas for future research. 


\section{Discussion of Key Findings}

When I began this research journey, I never expected to discover that the youth in my study would all hold such a high regard for higher education. Yet, as my results show, all of the students interviewed perceive a postsecondary education as necessity in today's society. Many wanted to attain some level of postsecondary, many had goals to go on and earn a university education. Consistent with the literature, the influence of family was an extremely important element in constructing an environment where pursuing a postsecondary education was seen as possible. Friends, teachers and community members were also identified as important sources of support, helping to reinforce students' values towards postsecondary studies. Social capital from friends played an extremely important role in (re)developing students' sense of place in the school system and their future plans and goals.

Place was also identified as being an important component of these rural youths' educational and career goals. The young people in my study had a strong sense of community, and valued the sense of family, friendliness, unity and safety they experienced while living on the Island. However, despite these strong feelings for the Island, the majority of participating students could not wait to leave the Island and explore the "real world".

Although distance was identified as an important influencing factor, most students chose to attend schools in places where they had established social networks including family, friends and peers groups. Students use their social networks to lessen their fears of leaving home and starting a new life in an unfamiliar, busy and often scary place. The literature has argued that youth, (especially rural youth), are affected by distance because they must leave home and cut important social networks. However, findings suggest that this group of students actually maintain some of their important social networks by moving to cities where close friends and 
peers are also attending school. They may also choose a college or university where they have family living or attending school, thus making this transition easier.

Income has been identified in some studies as an important indicator of the pursuit of a postsecondary education. The students who participated in this study, however, reported that despite the high cost of attending a postsecondary institution, pursuing a postsecondary education far outweighed the hardships of financial debt. The rewards of future job stability, a stable income, and the prospect of doing something enjoyable was worth any initial financial hardship. Given that many of the students in my study lack finance management skills, these students may not have the comprehension of the financial burden they are undertaking and therefore this aspect may not be a significant factor. Most of the students who participated in this study were intending to pay for their postsecondary studies without the use of OSAP, and therefore finances were not a consideration for many. If this study had attracted or targeted students from lower socioeconomic status families, the cost of attending a postsecondary institution may have been a more significant factor.

The role of teachers in promoting postsecondary participation is an important one that can encourage or discourage a student's aspirations. Overall, teachers are important role-models who provoke and encourage students to pursue further studies. Teachers not only help students to identify their strengths, they often help students to select specific educational paths which best utilize their strengths. However, a teacher's actions and words can negatively influence a student's sense of belonging and educational hopes and dreams. Thus, it is crucial that all educators be aware of how their actions or in some cases lack thereof, will affect their students.

Finally, although the literature identified cultural capital as an important component influencing students' academic choices, the results of this study did not yield any substantial 
results to support this fact, nor did it yield any results to the contrary. However, according to Corbett (2001), the transference of cultural capital in the form of local fishing knowledge was an important reason why young men chose to stay in the community of Digby Neck. Although it can be argued that the educational attainment levels of parents are one form of cultural capital transferred to youth, none of the students in my study desired to follow in their parents' footsteps. As a result, cultural capital may be more significant for those youth who wish to remain in the community, rather than for those who leave. Evaluating the importance of one form of capital over the other is beyond the scope of this study. However, it would be interesting to investigate the extent to which social and cultural capital influences rural youth, in their educational goals, as well as in their mobility trajectories.

\section{Limitations and Areas of Future Research}

This study identifies that students develop their sense of place in the community and society from their families, neighbours and peers, through their daily interactions with them. Students in this study had come to believe that a postsecondary education was necessary for them and that they should leave their community to pursue a postsecondary education. They also recognised that unless they chose a career path which they could use within the community, they would not be able to return to the community once they had completed their studies. Since the majority of students in this study are female (with parents with postsecondary education), this study is unable to identify how sense of place develops among the groups identified as most vulnerable: those more likely to drop out of high school, and less likely to pursue postsecondary studies. Specifically, 'vulnerable' refers to the population of rural youth who come from lower socioeconomic backgrounds, and who are male. Without studying this group of students, it 
remains unclear what factors influence one's sense of place most, and how these factors interact with one's sense of place.

Although Corbett's (2001) does identify that working class men had developed a sense of place, his study focused on older participants, and not on youth. Future research is needed where rural youth are the target, in order to understand how locality and social-spatial relations influence educational choices for younger rural populations. Also, in terms of Manitoulin Island, the inhabitants of this study area are not as isolated from urban centres as are the participants from the community of Digby Neck. This exposure to an urban environment, (no matter how limited), may also play a factor which could influence who stays, who goes, if they return and of course, why. A comparative study would be interesting in order to determine if this geographical component does in fact influence youths' sense of place, and educational and career choices.

I did not include the option of distance education as a means of earning a postsecondary education and neither did the students mention this option for themselves. Whether these students were aware of distance education opportunities or not, or whether they have considered distance education as an option for themselves, is a question beyond the scope of this study. However, since most of the students I spoke with seemed enthusiastic about the idea of leaving the Island to attain their educations I am convinced that they would favour pursuing a higher education elsewhere. Investigating the knowledge and inclination of various postsecondary options, (specifically distance education versus attending a postsecondary institution), would make an interesting future study.

Another limitation of this study was that I was only collecting research data within the high school for a very short period of time. A longitudinal study where students are tracked for a significant period of time would provide a better understanding of how one's sense of place 
changes over time. It might also provide a better understanding of those students who are less likely to pursue a postsecondary education, or which students might be at risk of dropping out of college or university in their first year.

Although there is a large Aboriginal population on the Island, they were not targeted directly in this study due to the short time frame of the study and the available window of time for data collection. As a researcher, I was also sensitive to the greater need to develop trust and rapport when entering First Nations communities (Greenhill and Dix, 2008). Aboriginal Peoples are also identified as a group of people in Canada most likely to have lower educational attainment levels (Jenkins, 200, Finnie et al., 2005). Future research on sense of place would benefit from understanding the social networks work in Aboriginal communities and how they foster postsecondary. In addition, there would be great benefits in promoting social and cultural networking beyond the community to encourage postsecondary education with Aboriginal youth.

Finally, with the growing use of communication technology such as e-mail, instant messenger, Facebook, Twitter, and Skype are connecting people the world over, the issue of distance is become less important. Since distance has been identified as a factor influencing rural youth's educational choices, it would be interesting to see how students' access to modern communication technologies are affecting their perceptions of distance.

\section{Concluding Thoughts}

I have been given many gifts as part of this research journey, and as a result, have uncovered the astonishing potential for unleashing the voices and stories of those seldom heard within society. Many of the students' and teachers' stories gathered during my interviews speak of the promising futures for many of these young people. However, what underlies many of their stories of hope and optimism is the possibility of failure, and the likelihood that others from the 
community will not continue on the same path. One participant, a male teacher, shared the following thoughts with me during an interview:

"And another thing, for some of the kids living in a city, it's new to them. Most of them have no trouble adjusting. But, thinking back to my group, there were a few that went to big cities like Toronto and London, and they came back, and they lost that first year. They came home. ... Then they went to Laurentian because it was close and they could come home, and they knew Sudbury. Most "Island Kids" know Sudbury 'cause it's the closest city" (Mr. N).

What speaks to me through the poignant words of $\mathrm{Mr} . \mathrm{N}$ is the observation that there are some students who are unable to cope with the factors surrounding leaving and living away from home in a large city, and therefore "they come home". I am now aware that the reality for some of these students is that they may not end up pursuing postsecondary studies, or they may drop-out entirely.

Although I was able to answer my initial research questions, I am now left with more questions regarding the issue of minimal postsecondary participation in rural communities. Who finishes postsecondary studies? Who drops out, and why? And, if they drop out, do they eventually go back to school? I am also left wondering if the same social-spatial processes influence young peoples' choices to drop-out of school and return home, or if there are other factors which affect these choices.

What I can be sure of is that the social-spatiality of a place is crucial to understanding the educational and occupational choices of youth at Manitoulin Secondary School. Who are the members of the community that stand out in the minds of students? What type of jobs do these figures hold in the community? How do they support youth and their future goals? These factors can be just as important to student success as one's family background and socioeconomic status, and that is not only true of Manitoulin Secondary School. If the cultural, social and economic landscapes are clearly forces that shape the lives of youth, then it seems imperative that 
community leaders celebrate the successes of students who do break free of the restrictions placed upon youth from a culturally and economically repressed area. At least then, they may "come home", but they will "come home" having pursued and accomplished what they set out to accomplish through postsecondary studies, hopefully with a vision to inspire others who live in their communities. 


\section{Bibliography}

Aitken, S.C. (2001) Geographies of Young People: The Morally Contested Spaces of Identity (New York, Routledge).

Ainsworth, J.W. (2002). "Why Does It Take a Village? The Mediation of Neighborhood Effects on Educational Achievement". Social Forces, 81(1), pp.117-152.

Barker, J. and Smith F. (2001) "Power, Positionality and Practicality: Carrying out Fieldwork with Children". Ethics, Place \& Environment, 4 (2), pp.142 - 147.

Barker, J. and Weller, S. (2003) "Geography of Methodological Issues in Research with Children". Qualitative Research. 3( 2), pp. 207-227.

Baxter, J and Eyles, J. (1997) "Evaluating Qualitative Research in Social Geography: Establishing 'Rigour' in Interview Analysis". Royal Geographical Society. pp 505-525.

Bell, A. (2007) "Designing and testing questionnaires for children". Journal of Research in Nursing.12(5), pp 461-469.

Bourdieu, P. (1977). Outline of a Theory of Practice (R. Nice Trans). Cambridge, UK:

Cambridge University Press. (Original work published in 1972).

Bourdieu, Pierre, and Jean Claude Passeron (1977) Reproduction in Education, Society, and Culture. London: Sage.

Bourdieu, Pierre, and Loïc J. Wacquant 1992 An Invitation to Reflexive Sociology. Chicago: University of Chicago Press.

Brooks, R. (2003), "Young People's Higher Education Choices: The Role of Family and Friends". British Journal of Sociology of Education, 24(3), pp. 283-297.

Bushnell, M. (1999) "Imagining Rural Life: Schooling as a Sense of Place". Journal of Research in Rural Education, 15(2), pp 80-89

Butlin, G. (1999) “Determinants of Post-Secondary Participation," Education Quarterly Review, 5(3), pp. 9-35.

Campbell, R and. Wasco, S. M. (2000) "Feminist Approaches to Social Science:

Epistemological and Methodological Tenets". American Journal of Community Psychology, 28 (6), pp. 773-791.

Castree, N.. (2003). "Place: Connections and Bounaries in an Interdependent World". In S. Holloway, S.P. Rice and G. Valentine (Ed) Key Concepts in Geography. London: SAGE Publications Ltd. pp. 165-186. 
Christofides, L.N., J. Cirello and M. Hoy. 2001. "Family Income and Post-Secondary Education in Canada (1975-1993)." The Canadian Journal of Higher Education.31(1), pp. 177-208.

Corak, M., G. Lipps and J. Zhao. 2003. "Family Income and Participation in Postsecondary Education." Analytical Studies Research Paper Series. Statistics Canada Catalogue no. 11F0019 MIE2003210.

Corbett, M. (2004) “"It Was Fine, if You Wanted to Leave':Educational Ambivalence in a Nova Scotian Coastal Community 1963-1998." Anthropology \& Education Quarterly, 35. pp 451-471.

-. (2005) "Rural Education and Out-Migration: The Case of a Coastal Community". Canadian Journal of Education / Revue canadienne de l'éducation, 28(1/2), pp. 52-72.

-. (2007a) Learning to Leave: The Irony of Schooling in a Coastal Community. Black Point, Nova Scotia: Fernwood Publishing.

-. (2007b) "Travels in Space and Place: Identity and Rural Schooling". Canadian Journal of Education, 30 (3), pp. 771 - 792.

Corterill, P. (1992) "Interviewing Women: Issues of Friendship, Vulnerability, and Power". Women's Studies International Forum, 15(5/6): pp. 593-606.

Crang, M. (2003) "Qualitative methods: touchy, feely, look-see?" Progress in Human Geography. 27 (4), pp. 494-504.

Crang, M and Thrift, N. (Ed). (2000) Thinking Space. London:Routledge.

De Broucker, P., and Lavallee, L. (1998). "Getting Ahead in Life: Does your Parents' Education count?" Education Quarterly Review. 5(1) pp 22-28. Statistics Canada, Catalogue no. 81003XIE.

Drolet, M. (2005) "Participation in Post-secondary Education in Canada: Has the Role Changed over the 1990s?" Analytical Studies Branch Research Paper Series, No. 243.

Dupuis, R., Meyer, F., and Morissette, R. (2000). "Rural youth: Stayers, Leavers and Return Migrants". Statistics Canada, Catalogue 11F0019MPE, No. 152.

Evans, B. (2008) “Geographies of Youth/Young People”.Geography Compass, 2(5), pp 16591680 .

Fernández Kelly, M. Patricia. 1994. "Towanda's triumph: Social and cultural capital in the transition to adulthood in the urban ghetto," International Journal of Urban

and Regional Research, 18, pp. 88-111. 
Finnie, R. 2002. "Student loans, student financial aid and post-secondary education in Canada." Journal of Higher Education Policy and Management. 24 (2), pp. 155-170.

Finnie, R., Laporte, C. and Lascelles, E.. (2004) "Family Background and Access to Postsecondary education: What happened over the 1990s?" Analytical Studies Research Paper Series. Statistics Canada Catalogue 11F0019 MIE2004226.

Finnie,R., Lascelles, E. and Sweetman, A. (2005) "Who Goes? The Direct and Indirect Effects of Family Background on Access to Post-secondary Education" Analytical Studies Branch Research Paper Series Catalogue no. 11F0019MIE. Analytical Studies Branch. Ottawa: Statistics Canada.

Frenette, Marc. 2002. "Too far to go on? Distance to school and university participation". Analytical Studies Research Paper Series. Catalogue no. 11F0019MIE2002191. Analytical Studies Branch. Ottawa: Statistics Canada.

- 2003. Access to college and university: Does Distance Matter? Analytical Studies Research Paper Series. Catalogue no. 11F0019MIE2003201. Analytical Studies Branch. Ottawa: Statistics Canada.

—. 2007. Why are Lower-income Students Less Likely to Attend University? Evidence from Academic Abilities, Parental Influences, and Financial Constraints. Analytical Studies Research Paper Series. Catalogue no. 11F0019MIE2007295. Ottawa: Statistics Canada.

Glendinning, A., Nuttall, M., Hendry, L., Kloep, M., and Wood, S. (2003) "Rural communities and well-being: a good place to grow up?" The Editorial Board of The Sociological Review, pp. 129-156.

Greenhill, J. and Dix, K. (2008) "Research with Rural Aboriginal Community". Social Indicators Research Series:Doing Cross-Culural Research. 34, pp 49-60

Hektner, J. M (1995) "When. Moving Up Implies Moving Out: Rural Adolescent Conflict in the Transition to Adulthood". Journal of Research in Rural Education, 11(1), pp. 3-14.

Hemming, P. J. (2008) "Mixing qualitative research methods in children's geographies". Area, 40 (2), pp. 152-162.

Hillier, J and Rooksby, E. Editors (2002) Habitus: A Sense of Place. Ashgate Publishing Limited: Hants, England.

Holloway, S. L., and Valentine, G. (eds) (2000). Children's Geographies: Playing, Living, Learning. London: Routledge.

Hoggart, K., Lees, L., and Davies, A. (2002). Researching Human Geography. London: Arnold. 
Holt, L. (2004) "The 'Voices' of Children: De-centring Empowering Research Relations". Children's Geographies, 2 (1), pp. 13 -27.

Indian and Northern Affairs Canada. (May, 2009). Ontario First Nations Map. Retrieved May 13, 2009, form http://www.ainc-inac.gc.ca/ai/scr/on/rp/mcarte/qwerty-eng.asp

-. (May, 2009) Manitoulin Island Treaties. Retrieved July 25, 2009) from http://www.aincinac.gc.ca/al/hts/tgu/pubs/Mtou/tremtou-eng.asp

Israel, G.D, Beaulieu, L. J, and Hartless, G. (2001) "The Influence of Family and Community Social Capital on Educational Achievement". Rural Sociology, 66(1), pp. 43-68.

James, R. (2001) "Participation Disadvantage in Australian Higher Education: An Analysis of Some Effects of Geographical Location and Socioeconomic Status". Higher Education, 42( 4), pp. 455-472.

Jenkins ,A. L. (2007) "Indigenous Postsecondary Institutions in Canada and the U.S". Ontario Institute for Studies in Education, 3(1), pp. 1-27.

Johnson, D. R. and Rahman, F. T. (2005) The Role of Economic Factors, Including the Level of Tuition, in Individual University Participation in Canada". The Journal of Higher Education, 35(3), pp101-127.

Jones, G. (1999) “"The Same People in the Same Places'? Socio-Spatial Identities and Migration in Youth". Sociology, 33(1), pp. 1-22.

Kobayashi, A. (2001) "Negotiating the personal and the political in critical qualitative research" In M. Limb and C. Dwyer eds Qualitative Methodologies for Geographers: Issues and Debates, pp. 55-72. London and New York: Arnold and Oxford University Press.

LAMBEC (2006) Regional Statistical Profile. Retrieved May 13, 2009 from http://www.lambac. org/ourregion.htm

Langevang, T. (2007) Movements in Time and Space: Using Multiple Methods in Research with Young People in Accra, Ghana, Children's Geographies, 5 (3), pp. 267 - 282.

Lehmann, W. (2005) "Choosing to Labour: Structure and Agency in School-Work Transitions". Canadian Journal of Sociology/Cahiers canadiens de sociologie, 30(3), pp. 325-350.

Lehmann, W (2007) "I just didn't feel like I fit in": The role of habitus in university dropout decisions. The Canadian Journal of Higher Education, 37(2), pp. 89-110.

Limb, M., and Dwyer, C.(Eds). (2001) Qualitative methodologies for geographers: Issues and debates. London: Arnold. 
Looker, D. E (1997). "In search of credentials: Factors affecting young adults' participation in postsecondary education." The Canadian Journal of Higher Education/La revue canadienne d'enseignement supérieur, 27(2), pp. 1-36.

Looker, D. E. (2001). Why don't they go on? Factors affecting the decisions of Canadian youth not to pursue post-secondary education. Montreal: Canada Millennium Scholarship Foundation.

Looker, D. E. and Andres, L. (2001) Rurality and Capital: Educational Expectations and Attainments of Rural, Urban/Rural and Metropolitan Youth. The Canadian Journal of Higher Education, 31(2)

Manitoulin-Island. Retrieved May 12, 2009 fromhttp://www.manitoulin-island.com/

Manitoulin Living. Retrieved Sept 9, 2009 from http:/www.manitoulinliving.com/ regional_profile.htm

Manitoulin Transport. Retrieved May 12, 2009 from http://www.manitoulintransport.com/

McDowell, Linda(1997) "Women/Gender/Feminisms: Doing Feminist Geography", Journal of Geography in Higher Education, 21(3), pp. $381-400$.

Morris-Roberts, K. (2001). Intervening in Friendship Exclusion? The Politics of Doing Feminist Research with Teenage Girls. Ethics, Place \& Environment, 4 (2), 147-153.

Nash, R. (1990). Bourdieu on Education and Social and Cultural Reproduction. British Journal of Sociology of Education, 11(4): 431-447

Ontario Student Assistance Program (OSAP) (2009). Retrieved July 18, 2009 from https://osap.gov.on.ca/eng/not_secure/plan_grants_full_newapp_1234_0910.htm

Ontario Trillium Foundation. (2007). Small Towns: Big Impact. Retrieced January 20 ${ }^{\text {th }}, 2009$ from http://www.trilliumfoundation. org/User/Docs/sm_towns/Small_Towns_Big_Impact.pd

Ontario Visual Heritage Project. (2008) Island of Great Spirit: The Legacy of Manitoulin Island. Retrieved July 18, 2009, from http://www.visualheritage.ca/manitoulin/

Painter, J. (2000) "Pierre Bourdieu". In M. Crang and N. Thrift (Ed). Thinking Space. London: Routledge. pp. 239-259.

Pretty, G. H., Chipuerb, H. M and Bramston, P. (2003) "Sense of place amongst adolescents and adults in two rural Australian towns: The discriminating features of place attachment, sense of community and place dependence in relation to place identity". Journal of Environmental Psychology, 23, pp. 273-287 
R.A. Malatest \& Associates Ltd. (2004) Aboriginal Peoples and Post-Secondary Education: What Educators Have Learned. Montreal, QC: Canada Millennium Scholarship Foundation. Retrieved March $20^{\text {th }}$, 2008, from http://www.millenniumscholarships.ca/images/ Publications/aboriginal_en.pdf

Reed-Danahay, D. (2004) Locating Bourdieu. Indiana: Indiana University Press.

Rose, D. (1993) "On Feminism, Method and Methods in Human Geography: An Idiosyncratic Overview”. The Canadian Geographer, 37, 57-60.

Rose, G. (1997) "Situating Knowledges: Positionality, Reflexivities and Other Tactics". Progress in Human Geography, 21 (3), 305-320

Statistic Canada. Community Profiles $<$ http://www12.statcan.ca/census-recensement/2006/dp$\mathrm{pd} /$ prof/92-591/Details/page.cfm?Lang=E\&Geo1=CD\&Code1=3551\&Geo2=PR\&Code2= $35 \&$ Data $=$ Count\&Search Text $=$ Manitoulin $\&$ Search Type $=$ Begins $\&$ SearchPR $=01 \& B 1=$ All\&Cust om $=>$ (accessed May 12, 2009).

Thomson, F. (2007) “Are Methodologies for Children keeping them in their Place?" Children's Geographies. 5 (3), $207-218$

Thrift, N. (2003). "Space: the Fundamental Stuff of Geography". In S. Holloway, S.P. Rice and G. Valentine (Ed) Key Concepts in Geography. London: SAGE Publications Ltd. pp. 95-108

Valentine, G. (1999) Being Seen and Heard? The Ethical Complexities of Working with Children and Young People at Home and at School. Ethics, Place and Environment, 2(2) Valentine, G., Butler, R. and Skelton, T. (2001) The Ethical and Methodological Complexities of Doing Research with 'Vulnerable' Young People. Ethics, Place \& Environment, 4 (2), pp 119 125 


\begin{tabular}{|c|c|c|c|c|}
\hline Scrina & Adathers & Fixns & FAX & Primcipas \\
\hline A. E. ES AUDE Sonoy & 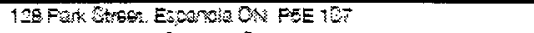 & $8 s e-t e s$ & $900-340$ & $7 \mathrm{~m}$ : now \\
\hline 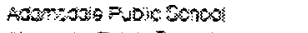 & 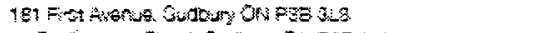 & $508-600$ & $500-2052$ & Gris souno \\
\hline Aexanoer Pubie cono & 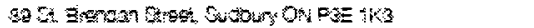 & $675-5004$ & - $75-1037$ & 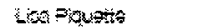 \\
\hline Agoran Food Pus Scho & 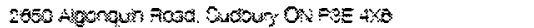 & $8: 2.9: 7 \div$ & $528-768 \overline{8}$ & kona boy \\
\hline Asignat Fustis Sthou & 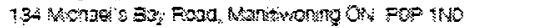 & $680-315$ & $\sec -4 \sin 2$ & Wano vorocs. \\
\hline C. F. veos Fuso smoo & 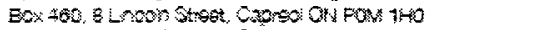 & $328-3881$ & $950-2000$ & 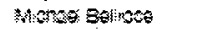 \\
\hline 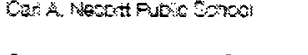 & 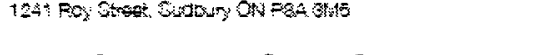 & $560-3935$ & $560-6 a 58$ & 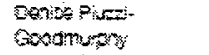 \\
\hline 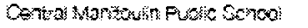 & SA tonos stast whor or on POF 100 & 37.835 & $37-5200$ & Tace Chapmar \\
\hline 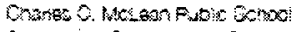 & 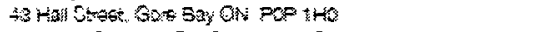 & $282+2083$ & $-28-2989$ & Ame Amotrong \\
\hline 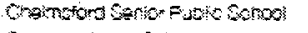 & 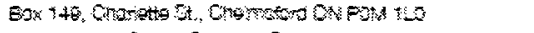 & 858.902 & 858054 & Matque Fib \\
\hline Costow Pusto Soloo & 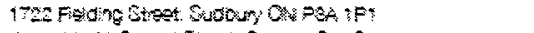 & $500-6100$ & $5,00-9254$ & Mar Frenct \\
\hline Gotoonch Fons Sood & 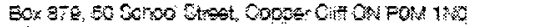 & $062-42$ & 200003 & Dant anon \\
\hline 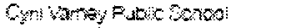 & 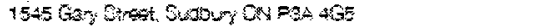 & $506-24 \hat{2} \div$ & $560-0052$ & Botoretri \\
\hline 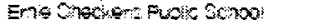 & 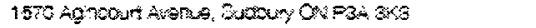 & $060-780$ & $560-424$ & 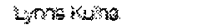 \\
\hline Gownes Sarnol & 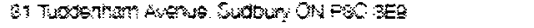 & $0: 2-8=8$ & $6: 4-605$ & Wo kevar $\{4\}$ \\
\hline Anow Progran Ementary & Atomones & & & \\
\hline Congs iangr fiode 9000 & 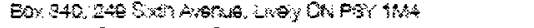 & $602-31+2$ & $609-8848$ & Mangrs \\
\hline jess Hamiton Pubic sroos & 16 . & $000-300$ & 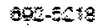 & soway $=\operatorname{seg}$ \\
\hline Sanoctumg Fuble Sonoo & 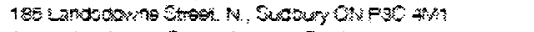 & $\theta+\theta-\theta i$ & $088-150$ & Onarta unow: \\
\hline Lombat Futes sonol & EDx 223,48 wan bast, cowng on Pon inc & $805-48 \pi 2$ & $855-0516$ & Drom counes \\
\hline Lente Pude Sono & 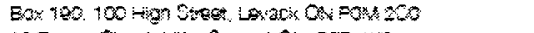 & $300-37 \%$ & POE- $2+70$ & $\cos \sin x$ \\
\hline 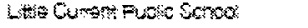 & 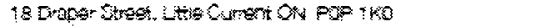 & $368-290$ & $662-390$ & Mroaret Stringer \\
\hline Long Lise Puto sonoo: & 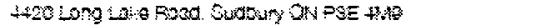 & $2=6 ! 68$ & $520-8041$ & $\operatorname{Lan} 30$ \\
\hline Malood Pubo snow & 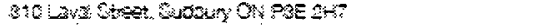 & 502.0046 & $50-4592$ & Ansti Gords: \\
\hline Marday Futsic Senos: & 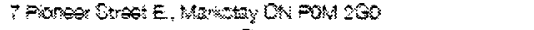 & 880.4546 & 858400 & Sathy wath d \\
\hline 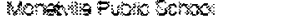 & 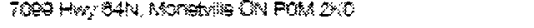 & 908.2788 & $\operatorname{ses} 354$ & Farm cemano \\
\hline thothearen Floto Sono: & 45 Sphoce Strest Grest ON Fat tPs & $200-110$ & & Daso Faros \\
\hline Fngerest Fuox nomo & 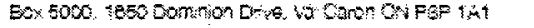 & $807-4981$ & $807-4458$ & Lasus whan \\
\hline 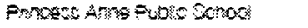 & 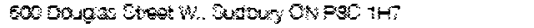 & $2+3-850$ & ars-ser & Gano, wangond \\
\hline Duen Eanoti / Puoric Sono: & 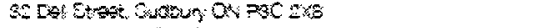 & 875649 & $0+178 x$ & we prey \\
\hline 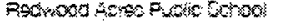 & 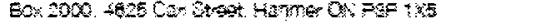 & $\operatorname{cop}-4+45$ & 960000 & Motele Wuator \\
\hline 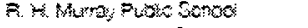 & Stany shent Whteren OF Fon GEO & $860-205$ & $868-1+28$ & Wack Aaloose \\
\hline R. L Sentie Futio 60nool & 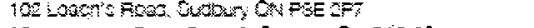 & $502-773$ & 50010 & Km kaman \\
\hline Ruth Matrinan cents & 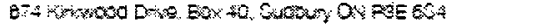 & $875-0493 \times 1830$ & $07-1008$ & Ho mover ins \\
\hline 5. Goger Pude sonoo & 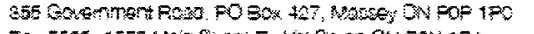 & $\sec -20 x 2$ & 868347 & Smora 400 \\
\hline 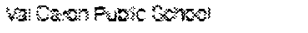 & 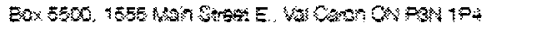 & Ee:67:3 & $897-245$ & Fou: Oupot: \\
\hline 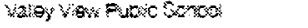 & 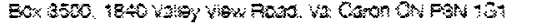 & $8+-38$ and & Q7t-5est & Faw 0,000n \\
\hline Wande Fuok 9 and & 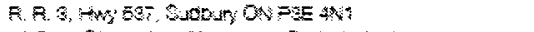 & exa- & $5+123$ & Portezin \\
\hline Wanten PUDC Sumod & 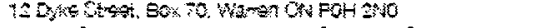 & $\theta 0 \% \cdot 2 \pi$ & $907+2008$ & katurath \\
\hline weos $\times 000$ - wolo Sinoo: & 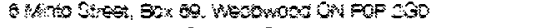 & 800.5.5 & & Hmacoonsi \\
\hline Nomber Fublo saroo: & 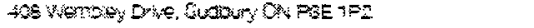 & ens- 08 & $67-7487$ & Compon kesona \\
\hline Boomount frigne Fidio Schoo & 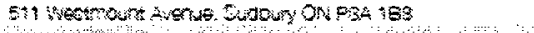 & $506-778$ & $506-8=00$ & 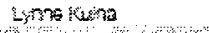 \\
\hline 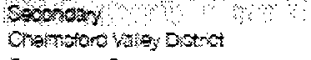 & 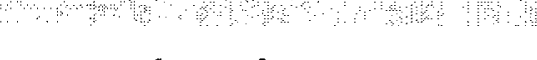 & H & & 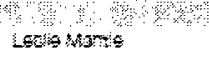 \\
\hline $\operatorname{concos} \operatorname{sen} 0$ & 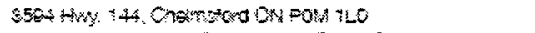 & $258-7504$ & $350-5000$ & \\
\hline 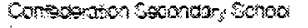 & 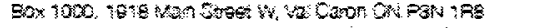 & $597-4968$ & $59 \overline{5}-420 \times$ & Methas \\
\hline Cat Foor Secondiay woros & 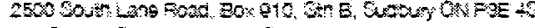 & $222-8198$ & $532-7054$ & Undo kenes \\
\hline Eapanoman schoo: & 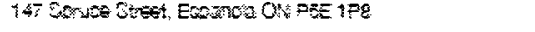 & $806-1560$ & & *t:at: Finati \\
\hline Lxas Soconory Sorooi & 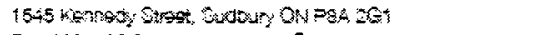 & $506-2083$ & $30 \mathrm{e}-1008$ & Cagnuman h: \\
\hline Leystrict sotondass sono & 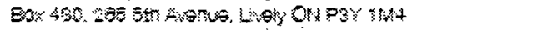 & $802-9 \theta^{-}$ & $29-9510$ & Woy hose \\
\hline Lockes comousts Sonos & 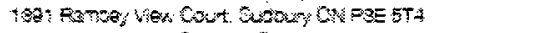 & 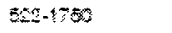 & $5=0-288$ & Buce Barret \\
\hline 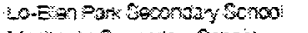 & 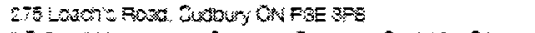 & $322-200$ & 520.873 & Hexpos \\
\hline Mantcum sachery scroos & 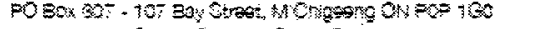 & $700-3)-5801$ & $27 \div-6583$ & aure zanox: \\
\hline 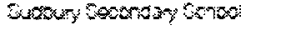 & 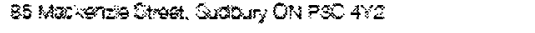 & $6-505:$ & $97 \div-535$ & Paromine \\
\hline Ada Cens Goondary & 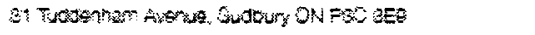 & $87+428$ & & Sra thovair ha \\
\hline
\end{tabular}




\section{Appendix C- PA Announcement to the Members of Manitoulin Secondary School on May $7^{\text {th }}, 2008$}

Manitoulin Secondary School, we have a guest visiting us from Carleton University. Her name is Kimberly Wilson and she will be visiting our school over the next few weeks. The reason for her visit is that she is doing a Master Degree at Carleton $U$ and is in the process of collecting data for a research project which is seeking to explore the perceptions and ambitions of youth living in rural communities.

Kimberly is looking for volunteers willing to fill out a short questionnaire and participate in a short interview or focus group which will be conducted during the school day, likely during your lunch period where snacks will be provided.

Consent forms to participate in the study will be distributed tomorrow morning during homeroom. These permission forms must be signed by your parents and returned to the school no later than Monday May $12^{\text {th, }} 2008$ in order to participate in the study.

All students who return their permission forms signed and participate in the research process will be entered into a draw to win an Ipod Nano. The odds of winning will depend on the number of participants and the draw will be held at the end of May.

The success of the project depends on the participation of the students of MSS, so if you are interested please don't forget to get a permission form and bring it home and get it signed and perhaps you will be the winner of the Ipod. 


\title{
Appendix D - Accent and Consent Form for Student Participants
}

\author{
Consent Form for Research Study: Identity, Space, Place and Postsecondary: Exploring the \\ Educational Perceptions and Ambitions of Youth of the Rural Communities of Manitoulin \\ Island \\ Kimberly Wilson, M.A. candidate, Department of Geography and Environmental Studies, Carleton \\ University, Ottawa, Ontario Tel.: (613) 725-0386. Email: kwilson6@connect.carleton.ca
}

\section{Introduction:}

Your child is being asked to take part in a study which will investigate the educational aspirations and expectation of youth living on Manitoulin Island. As part of my M.A. thesis requirements, I am interested in exploring how growing up in a rural northern Ontario community influences attitudes towards postsecondary education of high school students. With the permission of the Rainbow District School Board, this study will be conducted at Manitoulin Secondary School. As such, a significant amount of information for this study will come directly from the members of this school. Your child is being asked to take part in the study as a member of the school. It is my hope to gain a deeper understanding of how high school students from rural communities view postsecondary education, and if elements such as distance to postsecondary schools play a significant role in students' choices to pursue higher education. My hope is that this project will improve our understanding why postsecondary participation is lower among rural areas in Ontario than in urban areas.

Please read this form and ask any questions you may have before you agree to your child being in the study.

I would like your child to participate in the study if they are interested. Your child's participation is completely voluntary. If you decide to let your child take part in this study, he/she will be asked fill out a short questionnaire and to discuss their educational goals and expectations in an interview setting or ideas around place and future goals. The interview session will take place at school, throughout the school day (either during lunch or class time, unless other arrangements can be made). These interviews will take between 45-70 minutes, and your child may be asked to participate in 1 to 2 interview sessions. These interviews will be tape recorded, and notes using pen and paper will be used to record additional observations, make notes and backup the tape recordings in case of equipment malfunction.

\section{Confidentiality and Participant Safety:}

This research will be conducted with your child's best interest in mind. There are no major risks foreseen in participating in this study. However, since it is a small school and focus groups will be used as the main form of interview style for students in grade 9,10 and 11, students' anonymity cannot be promised. Although an agreement will be made with all members of the focus group, I cannot guarantee the complete confidentiality of personal information shared during the interview, I can however promise that no names or identifiable description of your child will be used in the reports of the findings. For students in grade 12, one-on-one interviews will be used, and therefore complete confidentiality is promised. I do realise that the research question is addressing an issue that is highly tied to family background and economics, and as such may be a sensitive area for some students to discuss. I will attempt to be as sensitive to the 
subject matter as possible and in the case of a focus group setting I will encourage others to do the same. Your child is under no obligation to answer any questions which make them feel uncomfortable, and if they wish to stop the interview at any time, your child is encouraged to let me know and I will end the interview immediately. If your child decides to end the interview, it will be up to your child to decide what should be done with the data your child has provided (e.g. whether to destroy the data or give consent to use it in the study).

For the purpose of this study your child's identity will be kept in confidentiality. Your child will be given a pseudonym to protect their identity in both the interview process and during the presentation of the findings. All participants of the focus groups will be encouraged to refrain from the use of true names during the interviews, or talking about the interviews outside of the interview setting. All notebooks and tape recordings will be kept in a secure location under lock and key at my own personal residence. The only people who will have access to the data collected in this study will be myself and my supervisor, Dr. Fran Klodawsky. After the research period, all data will be destroyed. Paper documents will be shredded and electronic files deleted.

I will be presenting my research findings in a final report that will be made available to participants with the Rainbow District School Board.

\section{Compensation for Participants:}

During the interview sessions, food and refreshments will be provided. In addition, all students who are active participants in the study (participate in the interview process) will be eligible for a chance to win an iPod nano. The odds of winning will depend on the number of participants in the study. The draw will be held on May 30th (date is subject to change) and the winning name will be drawn by the principal of Manitoulin Secondary School. The winner will be contacted and instructed on how to claim the prize.

\section{Questions or Concerns:}

If you have any concerns regarding your child's participation in the study, do not hesitate to contact me on my cell at (705) 562-6654 or at kwilson6@a)connect.carleton.ca. If you have further concerns you may contact: Dr. Fran Klodawsky, Associate Professor of the Department of Geography and Environmental Studies, Carleton University, Ottawa, Ontario. Tel.: (613) 5202600 ext. 8689. E-mail: fran klodawsky@carleton.ca or Prof. Antonio Gualtieri, Chair, Carleton University Research Ethics Committee, Carleton University, 1125 Colonel By Drive Ottawa, Ontario K1S 5B6 Tel.: 613-520-2517.

E-mail: ethicsacarleton.ca

If you consent to your child participating in this study, please sign and have you child sign the bottom of this page. A copy of the signed form will be given to you at a later date to keep for your own records. 


\section{Please return this page.}

\section{Contact information of the student:}

Name:

Phone number:

\section{Student Participant}

I __ , have read the following and would like to participate in (students name)

the following research study.

Students Signature $\quad$ Date

\section{Parent or Guardian}

I hereby give permission for my son/daughter to participate

(students name)

in this research study.

$\overline{\text { Subject Signature (or Parent or Guardian Signature) }}$ Date

Printed Name of the Subject or Parent or Guardian signing above

\section{Parent or Guardian Participation}

In addition to the study, I am interested in speaking with some parents about their perception of the educational expectations and ambitions of their child to gain a different perspective.

Are you interested in participating in this study? Yes or No

(please circle one)

Please provide contact information if you are interest in participating in the study

Phone:

E-mail: (optional) 


\section{Appendix E-Memo Administer to the Teaching Staff at Manitoulin Secondary School on May $28^{\text {th }}, 2008$}

\section{Dear MSS Staff,}

As you all know, I have been conducting interviews with students here at MSS. I am now looking for teachers who are willing to sit and talk with me about their own view of the perceptions and ambitions of the students here at MSS. I am interested in your perception of the socio-economic, cultural and geographic factors influencing postsecondary participation. If you are interested please fill in the bottom of this sheet and return it to the main office.

Thank you! 


\section{Appendix F -Consent Form for Teachers}

\section{CONSENT FORM FOR TEACHERS AND PARENTS}

Identity, Space, Place and Postsecondary: Exploring the Educational Perceptions and Ambitions of Youth of the Rural Communities of Manitoulin Island

Kimberly Wilson, M.A. candidate, Department of Geography and Environmental Studies, Carleton University, Ottawa, Ontario Tel.: (613) 725-0386. Email: kwilson6 a connect.carleton.ca

You are being invited to participate in a research study about the expectations and ambitions of rural youth attending Manitoulin Secondary School. You are being asked to participate in a short interview.

Please understand your participation is voluntary and you have the right to withdraw your consent or discontinue participation at any time without penalty or loss of benefits to which you are otherwise entitled. You also have the right to refuse to answer particular questions. There are no foreseen risks associated with this interview. Your individual privacy will be maintained in all published and written data resulting from the study.

If you have any concerns regarding your participation in the study, do not hesitate to contact me on my cell at (705) 562-6654 or at kwilson6aconnect.carleton.ca. If you have further concerns you may contact: Dr. Fran Klodawsky, Associate Professor of the Department of Geography and Environmental Studies, Carleton University, Ottawa, Ontario. Tel.: (613) 520-2600 ext. 8689. Email: fran_klodawsky 0 carleton.ca or Prof. Antonio Gualtieri, Chair, Carleton University Research Ethics Committee, Carleton University, 1125 Colonel By Drive Ottawa, Ontario K1S 5B6 Tel.: 613-520-2517. E-mail: ethics@carleton.ca

\section{$\underline{\text { Participant Consent }}$}

I , have read the following and would like to participate in (name)

the following research study. 


\section{Appendix G - Questionnaire}

Questionnaire: A survey of Students at Manitoulin Secondary School

Kimberly Wilson, M.A. candidate, Department of Geography and Environmental Studies, Carleton

University, Ottawa, Ontario Tel.: (613) 725-0386. Email: kwilson6(aconnect.carleton.ca

\section{Part A: Background Information:}

1. What is your name:

2. What is your age:

3. What grade are you in?

4. What is your sex:

5. How would you describe your ethnic background? (e.g. I am European -Canadian, my Friend is Chinese-Canadian)

Note: to help you describe your ethnic background better some of these descriptive terms might help: European (including French, British, Scottish, etc), Aboriginal, African, or Asian.

6. What is your first Language?
a) English
b) French
c) Other (specify):

7. Are you a Canadian Citizen?
a) Yes
b) No

8. Were you born in Canada?
a) Yes
b) No

9. What stream are you in:
a) Academic
b) Applied
c) Work place 
10. Where do you live on Manitoulin Island (name just the community or township):

11. Have you ever lived anywhere else?
a) Yes
b) No

If so, where:
12. Do you have any children?
a) Yes
b) No

13. What is your parent's marital status?
a) Married
b) Divorced
c) Other

If divorced did/do you live with your:
a) Mother
b) Father
c) Other

14. What type of family are you from?
a) Traditional "nuclear' family
b) One parent family
c) Blended family (parent remarried)
d) Other

15. If known what is your father's education level?
a) Less than grade 9
b) Grade 9 to 13
c) Some post-secondary 
d) A collage degree

e) A university degree

16. If known what is your Mother's education level?

- Less than grade 9

- Grade 9 to 13

- Some post-secondary

- A collage degree

- A university degree

17. Do you participate in any community activities? $\mathrm{Y} / \mathrm{N}$

(I.E: going to church, big brothers, team sports, volunteer event, etc)

List

all:

18. Do you read for pleasure? $\mathrm{Y} / \mathrm{N}$

19 . How many books would you say you read per year?

20. How many hours of TV do you watch in a day?

21. How many hours do you spend talking on the phone in a day?

22. How many hours do you spend on the Internet in a day?

23. How much time do you spend playing video games in a day?

Part B: Your educational Goals:

1. When I grow up I want to be a:

2. When I finish high school I want to:

a) Get a job and start working 

b) Go to college
c) Go to university
d) Other (specify):

3. When I finish high school my parents want me to:
a) Get a job and start working
b) Go to college
c) Go to university
d) Other (specify):

4. Most of my friends will probably:
a) Get a job and start working
b) Go to college
c) Go to university
d) Other (specify):

5. My teachers have encouraged me to:

- Get a job and start working

- Got to college

- Go to university

- Other (specify):

6. Does the cost of postsecondary play any role in influencing your choice of continuing your schooling after high school?
a) Yes
b) No

7. Does the fear of leaving home influence your choice to continue your schooling after high $\begin{array}{lll}\text { school? } & \text { a) Yes } & \text { b) No }\end{array}$ 
8. Does the fear of leaving friends influence your choice to continue your schooling after high school?
a) Yes
b) No

9. Do you believe that postsecondary education is important?
a) Yes
b) No

10. I plan on leaving Manitoulin Island after high school.
a) True
b) False

If True answer the following:

11. I plan on leaving Manitoulin Island after high school to:
a) find a job
b) attend college (where:
c) attend university (where:
d) other (specify):

12. If I leave Manitoulin Island, I plan on:
a) return home eventually
b) never moving back

Thank you for taking the time to fill out this Questionnaire!!!! 


\section{Appendix H - Protocol for Student Interviews}

Protocol for Interviews for Research Study: Identity, Space, Place and Postsecondary: Exploring the Educational Perceptions and Ambitions of Youth of the Rural Communities of Manitoulin Island

Kimberly Wilson, M.A. candidate, Department of Geography and Environmental Studies, Carleton University, Ottawa, Ontario Tel.: (613) 725-0386. Email: kwilson6@connect.carleton.ca

The Questions for the interviews will build on the information that is collected from the questionnaire.

Topics the interviews will cover are:

Students' future goals:

- Questions in this section will focus on students' plans for next year. The questions asked will encourage students to elaborate on the information they provided in the survey, and to have students share their attitudes towards taking this next step.

Questions:

- You reported in the questionnaire that you are going to go to postsecondary [Insert city/Insert school] - why did you choose to go there? Besides [Insert School], what other colleges/universities did/will you apply to?

- What program did/will you apply/enrol to/in? You said that you want to be a/an [inset Career]-What path do you need to take to reach your goal?

- You said that you are not concerned about to cost of postsecondary, can you elaborate on these feelings? How do you think that because you do not have to worry about the cost of postsecondary this has affected your choice to purse a postsecondary education? How are you going to pay for university?

- Have you been working? Would you say that working a part time job has prepared you for postsecondary studies? How? Has working a part time job hindered your preparation for postsecondary education at all, and why or why not?

- What emotions are you feeling/do you think you will feel about going to school? If so, what factors do you predict might change these feelings? In other words, how might these feelings change?

- You state that you have a fear of leaving home- why do you think you feel this way?

- You indicated that your parents and teachers have encouraged you to attend postsecondary - do you think that this has influenced your feelings towards leaving. You stated that you were nervous to leave friends - does this influence your choices to go away? Explain.

Students' perceptions of their community:

- Questions in this section will encourage students to talk about their community, including how they feel about their community and what their feelings are towards urban centers. 
These questions will, again, have students elaborate on the information provided in the survey.

- If you were to look up the word Community in the Dictionary, what do you think the definition would be? What is not a community?

- How would you describe your community? What are you feelings toward your community? What are some terms that you would use to describe Manitoulin Island and reflect your feelings towards Manitoulin Island? Can you elaborate on why you use these terms? Why do you think you have these feelings?

- If you were to think of urban places such as Toronto, Ottawa etc how would you describe these places compared to here?

- Do you think participating in community activities has increased your feelings towards your community?

- What sort of opportunities/attributes do you feel are available here that are not available elsewhere?

Perception of postsecondary education and its importance in the community.

- Questions in this section will encourage students talk about their perceptions of the values of postsecondary for them, and how they perceive their community attitude towards its importance. This section will build on the answers from each section before, as well as the survey.

- You stated that you think that postsecondary education is important - can you elaborate on your feelings - why do you think having a postsecondary education is important? Do you think your community share these values? Where do you see these values reflected in your community? Do you think there are people who do not value postsecondary and why do you think they hold these feelings?

- Who would you say has been the most influential person in influencing you and your choice to go on to postsecondary? Can you describe that person to me, their culture, age, etc. Can you explain what they did or said that made such an impact on your educational goals. Does this person still live in the community? Do you think they have influenced others?

- Focus on family structure-do you think that this has had any affect in your values towards postsecondary, your pursuit of a post-secondary education? How do you think coming from a broken or blended family would have influenced your values? Do you know of any example (without naming people, where this is so)?

- Do you feel that growing up in a rural area compared to an urban area has limited your options to go on to postsecondary? Or has limited your friends?

- In your opinion is there a difference between boys and girls attending postsecondary? Think of a person who you think will not be going on to postsecondary education, describe them. 


\section{Appendix I - Student Responses to Questionnaire -Select Questions}

\section{Characteristics of Sample Population}

\begin{tabular}{|c|c|}
\hline Sex & Count \\
\hline Male & 8 \\
\hline Female & 22 \\
\hline Age & Count \\
\hline 13 & 1 \\
\hline 14 & 2 \\
\hline 15 & 2 \\
\hline 16 & 6 \\
\hline 17 & 9 \\
\hline 18 & 9 \\
\hline 21 & 1 \\
\hline Grade & Count \\
\hline 9 & 4 \\
\hline 10 & 3 \\
\hline 11 & 10 \\
\hline 12 & 13 \\
\hline
\end{tabular}

\begin{tabular}{|l|r|r|r|}
\hline Steams & Count & Percent & $\begin{array}{l}\text { Cumulative } \\
\text { Percent }\end{array}$ \\
\hline Academic/University & 23 & 76.7 & 76.7 \\
\hline Applied/College & 5 & 16.7 & 93.3 \\
\hline Workplace & 2 & 6.7 & 100 \\
\hline
\end{tabular}

Socioeconomic Status of Sample Population

\begin{tabular}{|l|r|r|l|}
\hline Marital Status & \multicolumn{1}{l|}{ Count } & Percent & $\begin{array}{l}\text { Valid } \\
\text { percent }\end{array}$ \\
\hline Married & 18 & 60 & 62.1 \\
\hline Divorced & 6 & 20 & 20.7 \\
\hline Other & 5 & 16.7 & 17.2 \\
\hline
\end{tabular}

Note: 1 student did not answer this question

\begin{tabular}{|l|r|r|}
\hline Family Type & Count & \multicolumn{2}{|l|}{$\begin{array}{l}\text { Percent } \\
\text { (\%) }\end{array}$} \\
\hline $\begin{array}{l}\text { Traditional "nuclear" } \\
\text { family }\end{array}$ & 18 & 60 \\
\hline One parent family & 4 & 13.3 \\
\hline Blended Family & 6 & 20 \\
\hline Other & 2 & 6.7 \\
\hline
\end{tabular}




\begin{tabular}{|l|r|r|r|}
\hline Father's level of Income & Count & Percent (\%) & $\begin{array}{l}\text { Valid } \\
\text { Percent (\%) }\end{array}$ \\
\hline Less than grade 9 & 1 & 3.3 & 3.7 \\
\hline Grade 9 to 13 & 11 & 36.7 & 40.7 \\
\hline Some postsecondary & 3 & 10 & 11.1 \\
\hline A college degree & 3 & 10 & 11.1 \\
\hline A university degree & 9 & 30 & 33.3 \\
\hline
\end{tabular}

Note: 3 students did not answer this questions

\begin{tabular}{|l|r|r|r|}
\hline Mother's level of Income & \multicolumn{1}{l|}{ Count } & Percent (\%) & $\begin{array}{l}\text { Valid } \\
\text { Percent (\%) }\end{array}$ \\
\hline Less than grade 9 & 1 & 3.3 & 3.4 \\
\hline Grade 9 to 13 & 7 & 23.3 & 24.1 \\
\hline Some postsecondary & 4 & 13.3 & 13.8 \\
\hline A college degree & 7 & 23.3 & 24.1 \\
\hline A university degree & 10 & 33.3 & 34.5 \\
\hline
\end{tabular}

Note: 1 student did not answer this question

\section{Addition Information}

\begin{tabular}{|l|r|r|r|}
\hline $\begin{array}{l}\text { Participate in Community } \\
\text { Activities }\end{array}$ & Count & Percent (\%) & $\begin{array}{l}\text { Valid } \\
\text { Percent (\%) }\end{array}$ \\
\hline Yes & 23 & 76.7 & 79.3 \\
\hline No & 6 & 20 & 20.7 \\
\hline
\end{tabular}

Note: 1 student did not answer this question

\begin{tabular}{|l|r|r|}
\hline Do you read for Pleasure? & Count & Percent (\%) \\
\hline Yes & 24 & 80 \\
\hline No & 6 & 20 \\
\hline
\end{tabular}




\begin{tabular}{|l|r|r|}
\hline $\begin{array}{l}\text { Do the following factors } \\
\text { influence your choices } \\
\text { for next year? }\end{array}$ & Yes \\
\hline Cost & 20 & 23 \\
\hline Percent & 20.7 & 76.7 \\
\hline Valid Percent & 5 & 29.3 \\
\hline Fear of leaving home & 16.7 & 83.3 \\
\hline Percent & 7 & 23 \\
\hline Fear of leaving friends & 23.3 & 76.7 \\
\hline Percent &
\end{tabular}

Note: 1 student did not answer this question

\begin{tabular}{|l|r|r|}
\hline $\begin{array}{l}\text { Do you plan of Leaving Manitoulin Island } \\
\text { Eventually? }\end{array}$ & Count & Percent \\
\hline Yes & 29 & 96.7 \\
\hline No & 1 & 3.3 \\
\hline
\end{tabular}

\begin{tabular}{|l|r|r|}
\hline I plan on going to school in... & Count & \multicolumn{1}{|l|}{ Percent } \\
\hline Sudbury & 8 & 26.7 \\
\hline Toronto & 8 & 26.7 \\
\hline Kingston & 3 & 10.0 \\
\hline Kitchener/Waterloo & 3 & 10.0 \\
\hline Northbay & 2 & 6.7 \\
\hline Unknown & 2 & 6.7 \\
\hline London & 2 & 6.7 \\
\hline Barrie & 1 & 3.3 \\
\hline Outside of Canada & 1 & 3.3 \\
\hline
\end{tabular}

\begin{tabular}{|l|r|r|}
\hline $\begin{array}{l}\text { I plan on returning to Manitoulin Island } \\
\text { someday }\end{array}$ & Count & Percent \\
\hline Yes & 20 & 66.7 \\
\hline No & 7 & 23.3 \\
\hline
\end{tabular}




\section{Appendix $\mathbf{J} \square$ Flowchart Illustrating Thematic Connections}

Mapping the Factors Affecting the Perceptions and Ambitions of the Youth of Mantitoulin Island Towards Higher Education

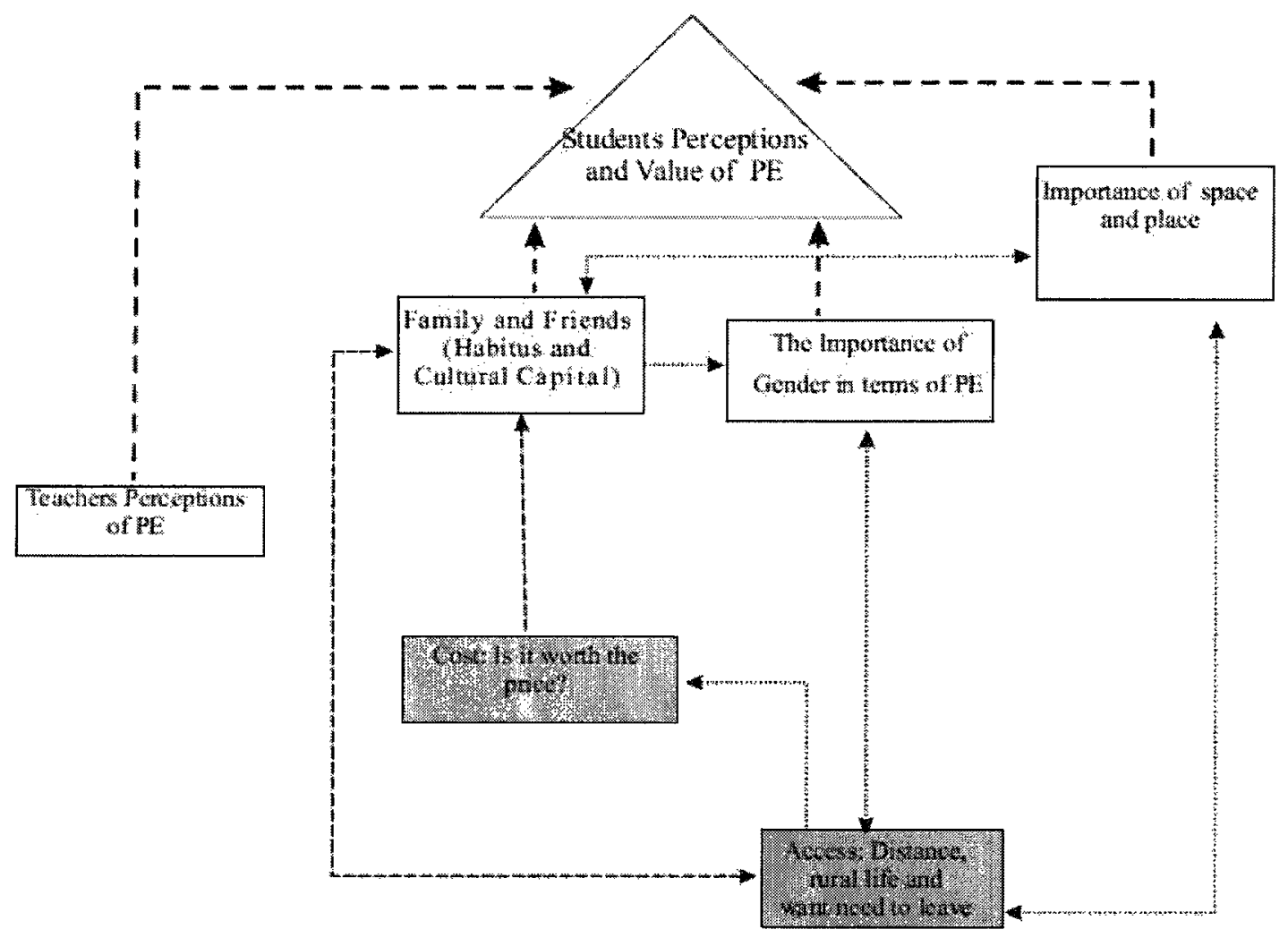


Glossary:

Agency: the privilege of personal choice of one's actions.

Capital: Assets available which can influence choices and be used in the production of further assets. E.g. Money (a form of economic capital) can be used to pay for postsecondary tuition to learn (a form of cultural capital).

Community: A group of people living in a particular area.

Cultural Capital: assets such as knowledge, experience and connections that are used by an individual which hold a specific value in terms of successes in society.

Habitus: is a set of acquired patterns of thought, behavior, and taste. These dispositions are the result of objective social structures through the experience of an individual or group.

Higher Education: Education beyond the secondary level, especially education at the college or university level.

Identity: As the distinct personality qualities or characteristics that makes a person definable and recognizable from other people or different types of people.

Ideologies: A way of looking at things, and or a persons tendencies to perceive things a certain way. Often ideologies are the result of exposure to a set of ideas proposed by the dominant class of a society to all members of that society.

Level of Educational Attainment: the measure of the level of postsecondary education was earned while attending a postsecondary institution at either the college or university, or vocational level.

Localitiy: An area considered as the site of certain activities (social and economic); a neighborhood. These places are made up of both physical and social environmental features which influence the development of our identities and ideologies.

Place: A geographic location such as a town, community or city, which is made up of both physical and social environmental features and to which meaning is given.

Postsecondary Attainment: The earning of a postsecondary education from either a college, university, or vocational institution.

Postsecondary Education: Any process of formal education which is experienced at a college, university, or vocational institution.

Sense of Belonging: the manner with which someone connects to a certain group or place. This is based on habitus or sense of place. Also defined as an internal set of dispositions which help individuals negotiate through their daily lives. 
Sense of Community: An individual's perception of the area where they live, both the social and natural.

Sense of Place: the intensely personal response to the environment, social and natural, which the individual experiences in daily life. This sense of place can include ones sense of belonging to a specific environment.

Social Capital: a term that refers to the connections between individuals and the reciprocal relationships that might be fostered to create further forms of capital. Social networks transfer social capital between individual and groups of people.

Social networks: a social structure which is made of individuals or organizations that are tied together by one or more specific type of interdependency. These may include issues of friendship, kinship, likes, dislikes, sexual relationships, relationships of belief, knowledge or prestige. Social capital is transferred between individuals in this social structure.

Social-spatiality: How people are influenced by their social environments (interactions with family/friends/community members. Also defined as the socially constructed opinions of the economy.

Space: Any given area, which has not been given specific meaning to an individual or group of individuals.

Youth: In this study, youth refers to any persons of high school age (13-21 years of age). 